University of Nebraska - Lincoln

DigitalCommons@University of Nebraska - Lincoln

Faculty Publications from the Harold W. Manter Laboratory of Parasitology

7-1953

On the Status of Some Arctic Mammals

Robert L. Rausch

University of Washington, rausch@uw.edu

Follow this and additional works at: https://digitalcommons.unl.edu/parasitologyfacpubs

Part of the Parasitology Commons

Rausch, Robert L., "On the Status of Some Arctic Mammals" (1953). Faculty Publications from the Harold W. Manter Laboratory of Parasitology. 497.

https://digitalcommons.unl.edu/parasitologyfacpubs/497

This Article is brought to you for free and open access by the Parasitology, Harold W. Manter Laboratory of at DigitalCommons@University of Nebraska - Lincoln. It has been accepted for inclusion in Faculty Publications from the Harold W. Manter Laboratory of Parasitology by an authorized administrator of DigitalCommons@University of Nebraska - Lincoln. 


\section{ON THE STATUS OF SOME ARCTIC MAMMALS}

\section{Robert Rausch*}

T

ThE mammal fauna of arctic Alaska is comprised of about thirty species, most of which are widely distributed. A few of these are essentially nearctic species, having extended their range northwestward during postPleistocene time. The majority, however, consists of forms which are either circumboreal in their distribution, or which have closely-related palearctic counterparts-considered specifically distinct by most North American mammalogists. Some of the foremost Old World workers, however, do not agree that Bering Strait constitutes a barrier which effectively separates the Old World fauna from the New.

North American mammalogists have not concerned themselves especially with the question of the distribution of boreal species, but rather have devoted themselves to the definition of local races. Some of the early investigators were aware of the strong tendency toward the circumpolar distribution of boreal species of mammals. Later workers, unfortunately, developed a remarkably restricted concept of mammalian speciation (e.g., Merriam's conclusions on species of the genus Ursus) which has seriously influenced the work of contemporary mammalogists.

In view of the recently intensified interest in arctic biology, with the attendant use of mammals by investigators working in diverse fields of research, it is more essential than ever to evaluate species relationships correctly. Such investigators cannot profitably maintain a provincial attitude toward speciation in North American mammals. To utilize pertinent literature concerning palearctic forms effectively, some of the nomenclatural complexities which obscure relationships must be eliminated.

The collection of Alaskan mammals has been essential to the investigations of the Animal-borne Disease Branch of the Arctic Health Research Center, at Anchorage, Alaska. Field work carried on for more than four years has resulted in the collection of approximately 4,500 mammals. The entire Territory has been covered, and considerable material has been obtained from regions where little or no work had previously been done. Since the survey phase of the work is nearly at an end, it seems desirable to summarize the information obtained.

Arctic mammals, mainly from the Brooks Range, have formed the basis for this paper, and each species is discussed in the light of holarctic distribution. Data on specimens from other parts of the Territory have been included whenever it would contribute to the clarification of the over-all distribution of a given species. An effort has also been made to synthesize the work of

*Arctic Health Research Center, Public Health Service, Department of Health, Education, and Welfare, Anchorage, Alaska. 


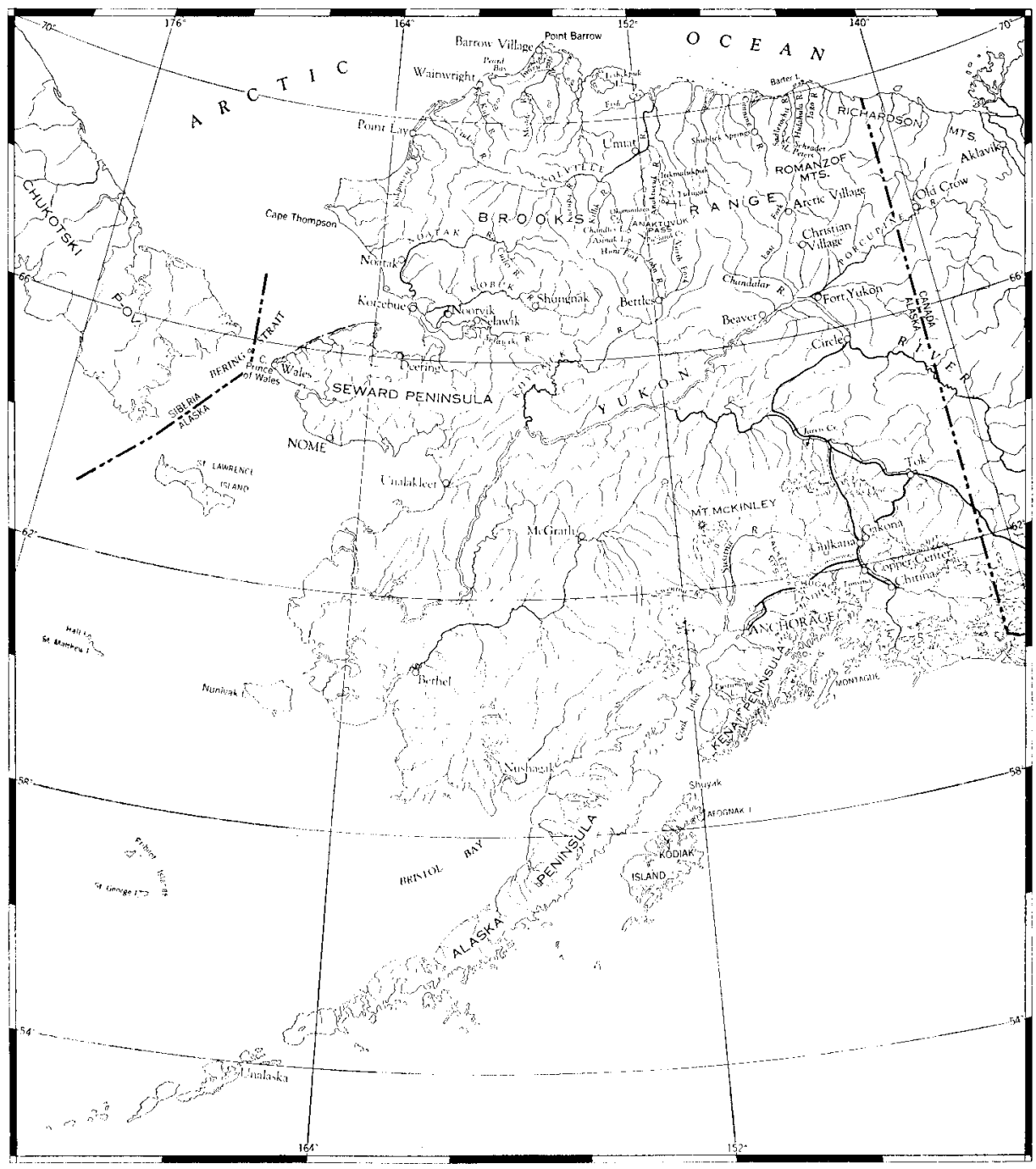

Fig. 1 .

mammalogists who have concerned themselves with problems relating to the distribution of boreal mammals.

Some additional records from the Anaktuvuk Pass region, in the central Brooks Range, have been included to supplement those published earlier (Rausch, 1951). Particularly valuable material has been obtained from two localities in northeastern Alaska where little mammal collecting had previously been done. Because of the importance of the specimens collected, it seems appropriate to include here brief descriptions of these two areas.

Romanz of Mountains: The high, rugged mountains of the Brooks Range lying between the headwaters of the Sadlerochit and Jago rivers, and extending to within a few miles of the Arctic Ocean, are called the Romanzof Mountains. 
The highest peaks of this group are more than 9,000 feet in altitude, and are snow-covered throughout the year. Two large lakes-Lakes Schrader and Peters-lie near these peaks, forty miles from the Arctic Coast, at an altitude of about 3,000 feet. Lake Peters, to the south, receives much glacier water and is consequently turbid. It is connected through a narrow channel to Lake Schrader, whose waters are clear. Lake Peters lies in a deep basin with steep walls to the east and west. The slopes along the western shore, however, are covered with willow (Salix alaxensis Cov.). Lake Schrader is surrounded by low rolling mountains covered with vegetation typical of dry alpine tundra. A large stream empties into this lake near its junction with Lake Peters, and extensive alluvial flats occur in this vicinity. These flats, as well as the stream banks, are grown to willow, and adjoin a marshy area at the south end of the lake. Polygonal formations are numerous in the marshy area, and the depressions support a dense growth of Carex spp. Sedge bogs are scattered along the lake and on the higher benches. Rock outcroppings are numerous on the ridges, and at the lower altitudes dwarf birch (Betula nana L.) is common. Water from the lakes drains off through a small stream at the north end of Lake Schrader, which flows into the Sadlerochit River a few miles north of the lakes. The steep valley of this stream supports the most luxuriant vegetation to be found in the region; for example, the willows are of exceptionally large size.

The Romanzof Mountain region has been described by Leffingwell (1919), and recent maps from air photographs have shown how accurate is his reconnaissance map of Lakes Schrader and Peters. His description of the area around the lakes is somewhat confusing at first glance as the names of the lakes have been transposed.

Arctic Village: Situated near the southern limits of the Brooks Range on the East Chandalar River, Arctic Village is about eighty-five miles south of Lakes Schrader and Peters. It is inhabited by Kutchin Indians, and its fluctuating population never exceeds 50 persons. Because of the isolated location of this village, the people depend for their livelihood upon hunting and fishing. The mountains here rise to about 6,000 feet. Lakes and ponds are numerous. The broad river valley is grown to spruce, and the taiga reaches its northernmost extent in Alaska in this region. The flora and fauna differ little from that of the southern timbered portions of the Brooks Range farther to the west.

\section{Mammals}

The species of mammals considered in this study are listed in systematic order. The specific names applied are correct insofar as I have been able to determine from a review of the literature and the study of comparative material.

Sorex obscurus obscurus Merriam. Dusky shrew.

The northernmost records of the dusky shrew are those of Rausch (1951), based on specimens from the north edge of the Brooks Range along the Anaktuvuk River. In northeastern Alaska I have not taken this species north of Beaver, on the Yukon River. No shrews of any kind were trapped in the 
Romanzof Mountains. A small collection of shrews from Arctic Village was lost in transit, and no specimens of $S$. obscurus have since been taken here. Jackson (1928) recorded S. obscurus from a place twenty miles north of Circle, on the Yukon River. I have no knowledge of any other reports of its occurrence in arctic Alaska.

Sorex cinereus ugyunak Anderson and Rand. Arctic cinereous shrew.

Although I have not collected S. cinereus in northeastern Alaska, previously published records indicate that it occurs there. Anderson and Rand (1945a) reported it from the "Chandalar River, east Branch, south slope of Brooks Range," and from "Hulahula River, at northern foothills of Brooks Range." I recorded it from Anaktuvuk Pass and Umiat (Rausch, 1951). In the Canadian Arctic, it has been reported from the vicinity of Aklavik (Anderson and Rand, 1945a) and from other localities farther east (Banfield, 1951a).

A related form, $S$. cinereus bollisteri Jackson, has been reported from "the tundra near Wainwright" by Bailey and Hendee (1926). The eastern limits of the range of this form are unknown, but it is essentially a west Alaskan subspecies. Quay (1951) reported it from the Seward Peninsula.

Sorex cinereus is widely distributed in boreal North America, but much additional material will be required to determine the distribution of the various races.

Sorex tundrensis Merriam. Tundra saddle-backed shrew.

S. tundrensis was collected at Arctic Village only in northeastern Alaska, but it appears to be distributed over the entire Arctic Slope and the Brooks Range. Hall (1929) reported the species from Barrow, and at the same time stated: "The species ranges entirely across Alaska, from the Seward Peninsula to the mouth of the Mackenzie River." The tundra saddle-backed shrew was reported to be of widespread distribution in the central Brooks Range region (Rausch, 1951). Quay (1951) reported it from the Seward Peninsula, and 12 specimens were trapped at Nome in December 1952 by E. L. Schiller, of the Arctic Health Research Center. In northwestern Canada, Anderson (1946) reported it from the Mackenzie Delta region.

It is probable that $S$. tundrensis is conspecific with the obviously similar $S$. arcticus Kerr. The latter occurs farther east, and inhabits essentially the taiga of central Canada. Although Jackson (1928) indicated that their ranges are not contiguous, it is likely that such a conclusion has resulted through a lack of collecting in the Mackenzie-Arctic Red River region. In my opinion, the characters used to differentiate $S$. tundrensis from $S$. arcticus have subspecific, rather than specific, value. The literature regarding these two forms has been reviewed by Jackson (1928).

$S$. tundrensis is, moreover, closely related to the palearctic $S$. araneus $\mathrm{L}$. Some of the earlier North American workers designated as $S$. araneus specimens later defined as $S$. arcticus. Regarding the affinities of $S$. araneus, Bobrinskiy et al. (1944) stated: "Very close forms (S. tundrensis and S. arcticus) are widespread from the western extremity of Alaska to central Canada." Chaworth- 
Musters, cited by Ellermann and Morrison-Scott (1951), concluded that races of $S$. tundrensis occur in Siberia. Such an opinion was not expressed by Bobrinskiy et al. (1944). These workers, in fact, reduced the number of species of Russian shrews to but six.

Workers interested in the distribution of shrews in arctic regions can at least be aware that $S$. araneus is the palearctic counterpart of $S$. tundrensisarcticus. Actual relationships, however, remain to be worked out on the basis of adequate comparative material and re-evaluation of morphological characters currently supposed to have specific significance. Some cranial details of these two species are shown in Fig. 2.
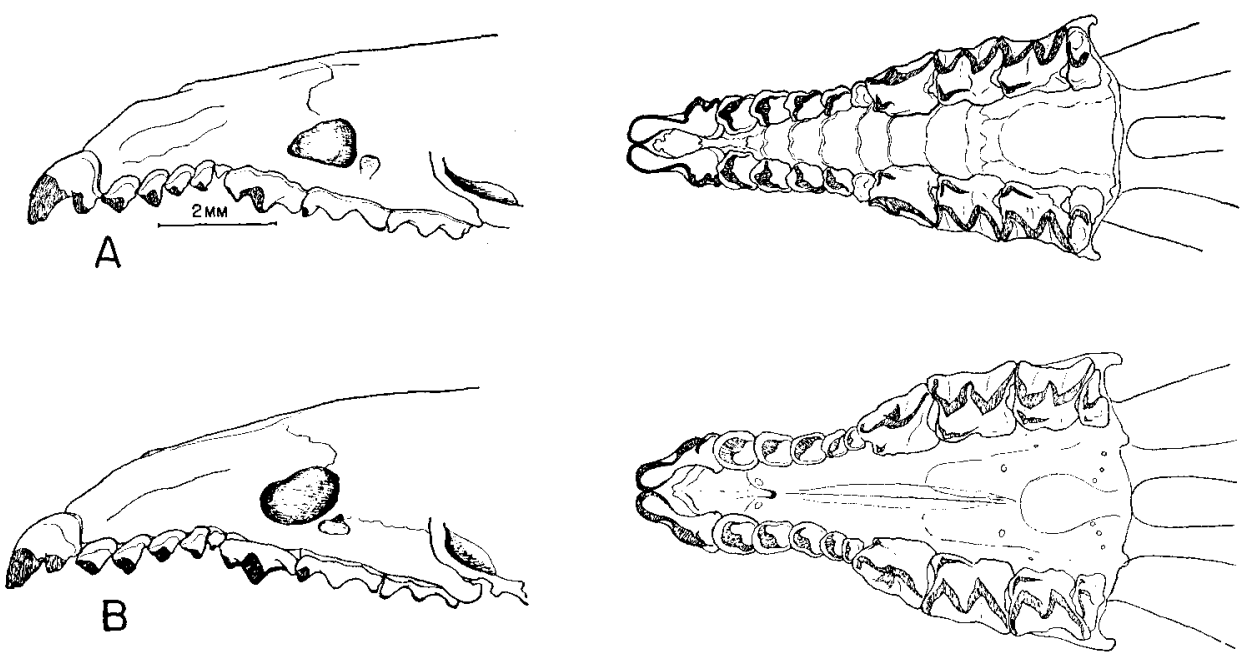

Fig. 2. Anterior portions of skulls of Sorex tundrensis (Alaska) (A) and Sorex araneus (Sweden) (B), showing dental and palatal characteristics.

Ursus aretos Linnaeus. Grizzly or brown bear.

Grizzly bears occur over all of arctic Alaska, but I have seen the largest numbers in the Brooks Range. Sign of bears was noted frequently in the Romanzof Mountains during the summer of 1951. A large dark brown adult, not collected, was observed feeding on the leaves of Salix alaxensis on the shore of Lake Peters. From the same general region, the skull of a specimen collected at Shublick Springs, in the valley of the Canning River, has been obtained (see Rausch, 1951). Farther south, the Indians of Arctic Village killed 8 of these bears during the summer of 1951. Of these, 4 specimens were secured for study. It is of interest that these Indians fear the bears, unlike the Eskimo farther to the west (Rausch, 1951), and will not attempt to kill them when hunting alone.

During the summer of 1952 the Nunamiut Eskimo killed a total of 7 bears in the vicinity of Anaktuvuk Pass. At least one additional animal was killed by poisoned baits disseminated by U.S. Fish and Wildlife Service predator 
control men. The records I have for this region show that 36 bears were killed over a period of five years. The majority was male, indicating that male bears probably range more widely than the females. Reliable information on the home-range of grizzlies under natural conditions is not available. It is not known what effect, if any, hunting has upon the movement of such bears.

The specific status of North American grizzly bears is one of the most complex problems of mammalian taxonomy. The difficulty stems directly from the work of Merriam (1918), who concluded that there are 86 forms of grizzlies (and brown bears) in North America. He stated: "One of the unlooked-for results of the critical study of the American bears is the discovery that the big bears, like mice and other small mammals, split up into a large number of forms whose ranges in some cases overlap so that three or more species may be found in the same region" (p. 9). Such a view is not tenable, but evidence to the contrary is not easily secured.

The grizzly has been exterminated over much of its former North American range. Although it still exists in considerable numbers in Alaska, the problem of obtaining adequate material for study is nevertheless serious. The killing of bears for scientific purposes cannot of ten be justified, because of the rapid reduction of their numbers now being brought about through sport hunting. I have been fortunate, however, in securing 22 skulls, several with skins, from the central Brooks Range region. Full data on sex, date, and place of capture have been obtained. Additional specimens from various other localities within the Territory have also been assembled and pertinent material in various public and private collections has been studied.

From this material, I have concluded that a single, but highly variable, species of grizzly bear occurs in Alaska, and I shall endeavour in this paper to substantiate this conclusion. The extreme degree of individual variation demonstrated by the Brooks Range specimens is considered particularly significant.

In assigning specific names to various specimens of grizzlies which he obtained, Merriam failed to take into consideration any possibility of individual variation. Some "species" were named on the basis of a single skull, and in some cases not even the sex of the animal was known. Simpson (1945) has appropriately remarked that: "C. H. Merriam distinguished about 90 species of North American bears alone, but he had a (fortunately) unique conception of the character of a species, giving it less scope than most authors give a minor geographic race, not much more than an individual genetic family group. On such a system twin bear cubs could be of different species." (p. 225, footnote).

Further, Merriam's system of bear classification was based upon the hypothesis that the "species" of bears occurring in the same region maintain their identity by segregated breeding. In reference to this, Merriam (1918, p. 8) stated: "Some writers have advanced the view that the various species of bears freely interbreed. Let those so minded ask themselves the question, If promiscuous interbreeding were to take place, what would become of the species?". It would seem that Merriam concluded a priori that the species existed, and then went about finding means to support such a conclusion. 
It is difficult to obtain much data on the breeding habits of bears. Most animals coming under close observation are usually seen over the sights of a rifle, and rarely live long enough to carry on their normal activities. Murie (1944) described the mating activities of two physically different male bears with a single female in the Mount McKinley region. Anyone working in a place where grizzlies still occur will soon note a lack of uniformity in the physical characteristics of the animals. Grizzlies, particularly males, travel considerable distances. This, together with their low density in most regions, suggests that breeding occurs on a chance basis alone. Under the stresses of breeding time it is most unlikely that bears are very selective in their matings, but rather that they must copulate according to opportunity. This is a fundamental concept which $I$ adopt as valid. If one must wait until a large series of grizzlies, collected after having been observed in coitu, has been assembled, the problem is hopeless. If my conclusion that the grizzlies of Alaska represent but one species is valid, certain generalizations are possible.

It seems necessary first to consider separately the various characteristics used heretofore to differentiate species of grizzlies, in the light of a broader species concept.

\section{External characteristics}

Size: Grizzlies in Alaska vary greatly in size, even in the same locality. Over the Territory as a whole, the largest animals occur on Kodiak Island and the Alaska Peninsula. In other regions the adult bears vary in size between rather broad limits. In the Brooks Range, where I have made the most observations, the adult bears range from about 400 to 700 lbs., the latter weight though is rare. Such a size range appears to be characteristic of grizzlies over most of interior Alaska. Specimens from southeastern Alaska have not been considered in this study.

On Kodiak and Afognak islands, and on the Alaska Peninsula, the species attains its greatest size in North America. Extremely large animals are becoming scarce as a result of incessant hunting pressure, but specimens weighing from 1,200 to, perhaps, 1,500 lbs. are still killed occasionally. The maximum weight attained by these bears is not known, but the greatest reliable weight of which I know is 1,200 lbs. Weights exceeding 1,500 lbs. are frequently reported, but these are estimates and cannot be considered accurate.

The largest grizzlies in a given region are males, but some females exceed small males in size. There is rarely size-uniformity in a grizzly population. The majority of animals may be of about the same size, but unusually large and unusually small individuals are seen. Size depends in part upon age and condition. After full growth is attained, an individual bear varies in weight according to the season of the year, depending upon the amount of fat present. Very old animals, usually with broken and badly worn teeth, are often in poor condition, and in general have the lowest weights.

Measurements of external proportions of bears are so few that they have little or no value at present. Age, size, and sex all influence the various dimensions. Sport hunters regularly measure the length and width of the green hide. 
I have made a few observations on these measurements, which confirm the obvious conclusion that they are worthless for scientific purposes, since they reflect only the enthusiasm and strength of the hunter and his guide.

It is noteworthy that maximum size in Ursus arctos is attained where an unlimited supply of high protein food is available. Thus, on Kodiak and Afognak islands, and, to a lesser degree, on the Alaska Peninsula, heavy salmon runs provide food during all of the warmer months when the bears are active. On Kodiak Island, the red salmon (Oncorbynchus nerka (Walbaum)) is available from late June to late September in the streams, and from late May at least until late November along the lake shores. Other species are abundant for shorter periods during the summer months. The same situation exists in Asia. In northeastern Siberia, particularly Kamchatka, great salmon runs occur. Here also $U$. arctos beringianus attains the largest size of any Eurasian form of $U$. arctos. For this form, Bobrinskiy et al. (1944) gave a maximum skull length of $445 \mathrm{~mm}$. According to Johnson (1947) this bear attains a weight of $560 \mathrm{~kg}$. in winter.

Colour: The colour of grizzlies is highly variable and, in my opinion, it has little or no taxonomic value. In the Brooks Range grizzlies range in colour from very pale (near Ridgway's Ivory Yellow, ${ }^{1}$ but paler) to nearly black (near Blackish Brown). Some animals are entirely light-coloured, except for the legs and belly, but most have the buffy colour restricted to the head, shoulders and back. Despite the great range in colour, the general pattern is essentially the same: head and shoulders lighter, back and sides dark, belly dark, and legs and feet darkest. Even the very pale specimens have dark feet and legs, usually with a reddish tinge. It is true that the bears of a given region may be of predominantly one colour, but lighter or darker specimens are almost always observed. The bears of the Alaska Peninsula and KodiakAfognak may, in general, be more uniformly coloured, but on Kodiak Island I have examined specimens as light-coloured as any observed on the mainland, while others are very dark.

Claws: Grizzly claws are very variable in shape, size, and colour. Shape (curvature) and size depend mainly upon season of the year. Animals killed in the early spring usually have long, well-formed claws, but later they become badly worn through use. Extent of wear depends upon the terrain, rocky soils causing more rapid wear than others, particularly in places where bears frequently dig for rodents. When other food (e.g., salmon) is available, less wear results. Claw shape and size also appear to vary individually.

Claw colour varies from white to nearly black, and is related to some extent to the degree of pigmentation of the fur. Very pale-coloured bears in general have white or very light claws.

\section{Internal characteristics}

The skull: The differentiation of grizzly "species" has been based mainly on skull characters. Among these, skull size, relative proportions, and details of dentition have been considered important. Merriam (1918, p. 13) stated:

${ }^{1}$ Capitalized colour names are from Ridgway, R., 'Color standards and color nomenclature,' 1912. 
"Cranial and dental characters among the big bears are very subtle. As a rule comparison of any two skulls of essentially the same size brings to light so many resemblances that one is likely to infer a far closer relationship than actually exists. This is because the big bears of the genus Ursus are such a closely interrelated group that the resemblances far outnumber the differences. Hence the greatest caution is necessary to avoid misleading conclusions."

The paucity of good series of bear skulls with complete data from any one region has in part prevented an evaluation of individual variation. However, even when good material has been available, the problem of variation has been little considered. Regarding the Alaska Peninsula bears, Merriam (1918, p. 125) stated: "Skulls of adult males which it seems necessary to call gyas present a surprisingly wide range in size and form. Among them are three quite different types which if isolated would undoubtedly develop into very distinct species." Merriam did not state why, in this case, he considered such "different types" to be conspecific. On the other hand, he considered $U$. kidderi kidderi Merriam, which has the same range as $U$. gyas, to be specifically distinct despite his statement: "Males of kidderi are sometimes hard to tell from females of gyas. .. (p. 107)". As far as I can determine, a single form, showing the usual variability, is found on the Alaska Peninsula. Its status is discussed in more detail below.

Bears occurring on Kodiak Island, hitherto known as $U$. middendorffi Merriam, are also quite variable. It is true that large adults show cranial characteristics which are relatively constant, but nevertheless some individuals differ strikingly from such "typical" specimens. I have examined a large series of skulls of this form, and Allen (1903b) studied 30 skulls of Kodiak bears and summarized their measurements. This form is likewise considered further below.

A small series of bears from the Alaska Range, designated as Ursus toklat Merriam, is in the collection of the U.S. National Museum. The skulls which I have examined have been relatively uniform, but show minor structural differences. The bears of the Mount McKinley region have been observed by several workers in the field, and nearly all of them have remarked on obvious physical differences.

The most significant bear material I have obtained consists of 22 skulls, with full collecting data, from arctic Alaska. These specimens, taken in the Brooks Range, exhibit unusual cranial variation. Some brief remarks on variation in Brooks Range bears were included in another paper (Rausch, 1951), under the species name $U$. richardsoni Swainson. Among these skulls, several adult male specimens differ conspicuously from one another, despite their having been killed in the same general region. Four specimens of unusual interest are shown in Fig. 3, and their measurements are given in Table I. All but one of these bears (orig. No. 9849; U.S. Nat. Mus. No. 293782) were killed in the Anaktuvuk Pass region of the central Brooks Range. They probably comprised interbreeding members of a single population. These animals, mature or aged males, were among 35 bears killed over a period of five years in the Anaktuvuk Pass region. 
Rausch in Arctic: Journal of the Arctic Institute of North America (July 1953) 6(2).

Copyright 1953, Arctic Institute of North America. Used by permission.
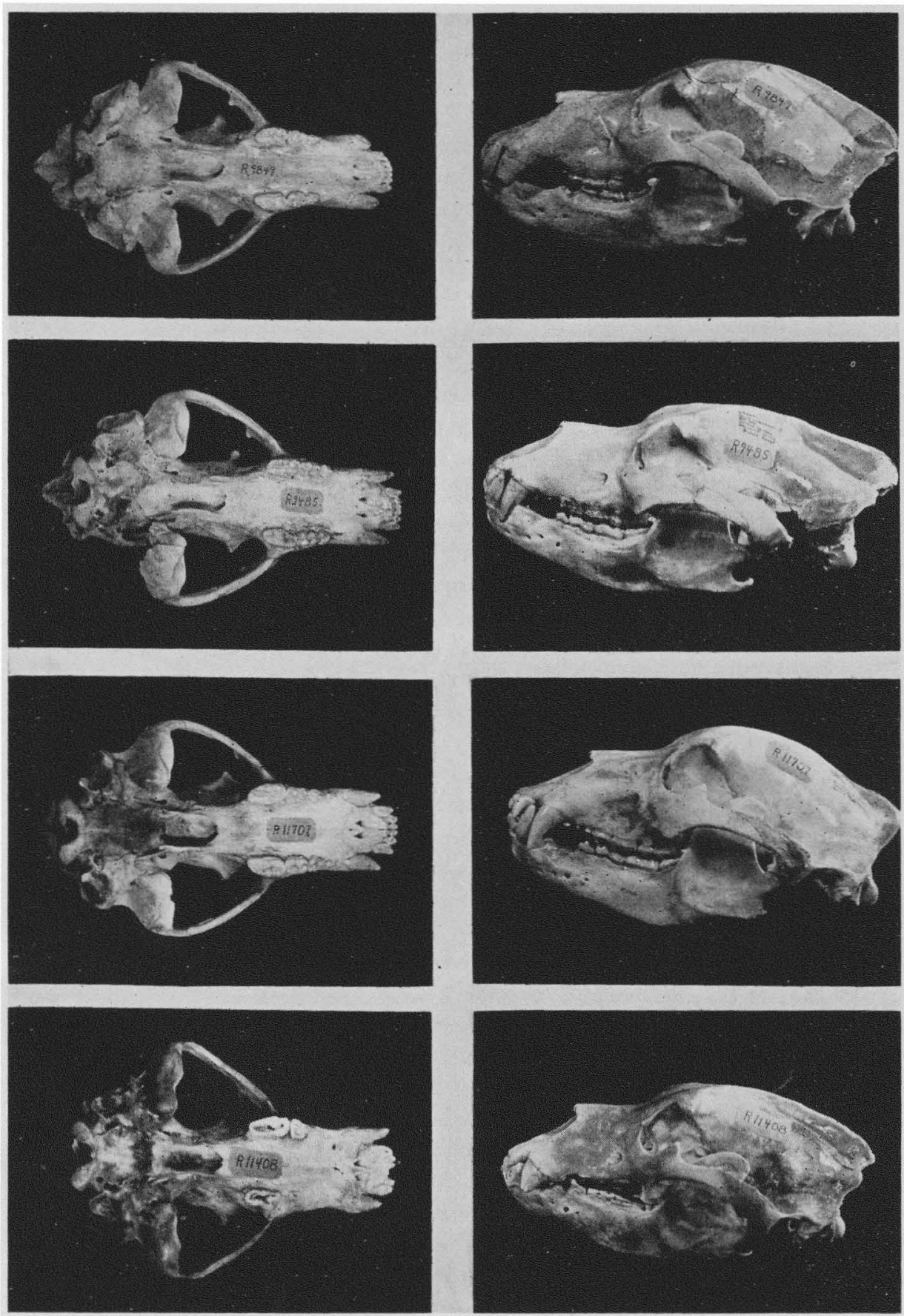

Fig. 3. Skulls of 4 specimens of Brooks Range grizzlies, all old or aged males, showing individual variation. Measurements are given in Table 1. 


\begin{tabular}{|c|c|c|c|c|c|c|c|c|c|c|}
\hline No. & Locality & Sex & $\begin{array}{c}\text { Condylo- } \\
\text { basal } \\
\text { length }\end{array}$ & $\begin{array}{l}\text { Zygo- } \\
\text { matic } \\
\text { width }\end{array}$ & $\begin{array}{l}\text { Inter- } \\
\text { orbital } \\
\text { width }\end{array}$ & $\begin{array}{c}\text { Palatal } \\
\text { length }\end{array}$ & $\begin{array}{c}\text { Post- } \\
\text { palatal } \\
\text { length }\end{array}$ & $\begin{array}{c}\text { Upper } \\
\text { toolh row } \\
\text { length }\end{array}$ & $\begin{array}{c}\text { Last } \\
\text { upper molar } \\
\text { length }\end{array}$ & $\begin{array}{c}\text { Mastoid } \\
\text { zeidth }\end{array}$ \\
\hline \multicolumn{11}{|l|}{ Fig. 3} \\
\hline R9849 & Arctic Village & $\sigma^{7}$ & 358.6 & 236.8 & 87.0 & 185.0 & 166.5 & 140.2 & 35.2 & 186.0 \\
\hline $\mathrm{R} 11707$ & Okominilaga Cr. & $\sigma^{\pi}$ & 335.5 & 218.3 & 83.3 & 173.8 & 155.8 & 128.6 & 37.8 & 155.7 \\
\hline R9485 & Savioyok $\mathrm{Cr}$. & $\sigma^{7}$ & 336.2 & 220.5 & 80.0 & 177.0 & 154.3 & 127.0 & 34.6 & ........ \\
\hline R11408 & Upper John R. & $\sigma^{7}$ & 307.4 & 221.7 & 83.0 & 162.7 & 137.6 & 127.0 & 38.7 & - \\
\hline \multicolumn{11}{|l|}{ Fig. 4} \\
\hline ITSNM & 292125 Tulugak L. & ? & 199.0 & 119.0 & 48.1 & 104.5 & 88.3 & - & $-\ldots$ & 84.2 \\
\hline R 10533 & Arctic Village & $\sigma^{7}$ & 236.3 & 131.8 & 53.1 & 124.8 & 108.0 & 108.0 & 37.4 & 95.1 \\
\hline R11588 & Anaktuvuk Pass & 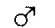 & 244.5 & 136.7 & 53.8 & 130.5 & 110.6 & 109.1 & 36.5 & 96.8 \\
\hline R11710 & Inuk pasukruk Cr. & 9 & 271.5 & 151.0 & 59.6 & 139.0 & 128.6 & 113.1 & 33.9 & 108.8 \\
\hline R12018 & Inukpasukruk Cr. & $\sigma^{7}$ & 276.0 & $-\ldots$ & 57.9 & 141.5 & 129.0 & 109.3 & 32.6 & -- \\
\hline R12650 & Anaktiuvuk Pass & ? & 28.3 .1 & 158.6 & 62.2 & 148.4 & 132.4 & 108.5 & 34.1 & 117.2 \\
\hline \multicolumn{11}{|c|}{ Fig. 5} \\
\hline R11680 & Cold Bay & $\sigma^{7}$ & 429.1 & 281.9 & 94.8 & 214.0 & 204.7 & 157.4 & 36.5 & 237.1 \\
\hline \multicolumn{11}{|l|}{ Fig. 6} \\
\hline R12688 & Olga Bay, Kodiak I & I. $0^{7}$ & 411.5 & 295.0 & 96.0 & 208.9 & 196.0 & 153.2 & 37.6 & 242.0 \\
\hline
\end{tabular}

According to Merriam's system of bear classification, it would be acceptable to consider each of these 4 animals representative of a different species. I am convinced, however, that such is not the case. In another paper (Rausch, 1951, p. 165), it was stated, regarding the Alaskan distribution of $U$. richardsoni, that it "is widely distributed, and in Alaska its range appears to encompass at least the entire region north of the southern limits of the Brooks Range, including the Arctic Slope." It is necessary here to discuss also some of the species recorded from farther east, particularly in northern Canada.

In 1949 I studied pertinent bear material from arctic North America which has been deposited in various museums. Dr. R. M. Anderson kindly reviewed with me much of the material in the collections of the National Museum of Canada, among which were the type of $U$. internationalis Merriam, a large series of $U$. richardsoni which had been collected by Dr. Anderson, and a series of $U$. macfarlani Merriam. The study of this material and comparisons with Alaskan specimens led to the conclusion that all were conspecific. This was substantiated by the study of material in the U.S. National Museum, and in the American Museum of Natural History. Further work in Alaska has supported this conclusion.

As a result of the earlier work, it was concluded that a single species of bear extended across the entire North American Arctic. The variation observed in the Brooks Range bears has permitted a better concept of normal individual variation in grizzlies, and other Alaskan "species" may now be considered.

The comparison of my material with single specimens supposedly representing different species obviously had little value, since it was not possible to distinguish specific differences from individual differences. Where small series were available, as with $U$. toklat Merriam, from the Mount McKinley region, and Ursus sp. from Jarvis Creek, only small inconsistencies were sometimes noted. In light of observations made on the Brooks Range specimens, such differences cannot be considered significant. Moreover, the examination 
of miscellaneous specimens from Alaska south of the Brooks Range has failed to disclose anything to support the concept that any of these differ specifically from the more northern specimens.

For the purposes of this paper, it seems impracticable to consider separate skulls in detail. There is apparently so much individual variation in bear skulls that generalizations regarding the animals of a given locality can rarely be made. A great range in skull size is to be expected. There may be considerable variation in the length/width ratio of the skull (condylo-basal length/zygomatic width) from a single locality. Skull profile is subject to much variation. In some cases the frontal region is gradually sloping and concave, while in others it is inflated and slopes abruptly. Rostral length is variable, and the nasals may show considerable range in length. The saggital crest may show much variation in degree of development, height, and antero-posterior extent. Variation is to be expected in the length and width of the palate. The ramus of the mandible varies greatly in form and relative length. The angle formed by the long axis of the skull with the horizontal, when the skull is at rest on a flat surface, differs from one individual to another largely on the basis of mandible shape. The maxillary tooth row shows considerable variation in length. The length of the last upper molar is highly variable. In the four skulls shown in Fig. 3, molar length ranged from 34.6 to $38.7 \mathrm{~mm}$., and in a series of $U$. toklat, molar length ranged from 36 to $40 \mathrm{~mm}$. A very large bear from the lower Alaska Peninsula had a molar length of only $36.4 \mathrm{~mm}$., even though the condylo-basal length of the skull was $402 \mathrm{~mm}$. Relative massiveness of dentition is highly variable. General massiveness of the skull, though related to age of the individual animals, is nevertheless subject to variation. Figure 4 demonstrates cranial changes associated with growth in $U$. arctos; the measurements for these specimens are included in Table I.

As a result of the study of Alaskan bears, I have no alternative but to conclude that a single, highly variable species occurs in the Territory. Excluding southeastern Alaska, 14 Alaskan species of grizzlies were recognized by Merriam (1918), as follows: (type locality indicated)

$U$. orgiloides Merriam (Italio River)

$U$. alascensis Merriam (Unalaklik River)

U. toklat Merriam (head of Toklat River)

$U$. pheonyx Merriam (Tanana Mountains)

U. internationalis Merriam (AlaskaYukon boundary)

$U$. kidderi kidderi Merriam (head of Cook Inlet)

$U$. kidderi tundrensis Merriam (Norton Sound)

To this list should be added $U$. richardsoni Swainson, reported from Alaska by other writers.

Early investigators in North America, such as Richardson (1829) considered the grizzlies conspecific with the palearctic $U$. arctos Linnaeus. Acceptance of Merriam's concept would preclude consideration of this possi-
$U$. eximius Merrian (Knik Arm, Cook Inlet)

$U$. innuitus Merriam (Seward Peninsula)

$U$. cressonus Merriam (Wrangell Range)

$U$. alexandre Merriam (Kenai Peninsula)

$U$. gyas Merrian (Alaska Peninsula)

$U$. middendorffi Merriam (Kodiak Island)

U. kenaiensis Merriam (Kenai Peninsula) 

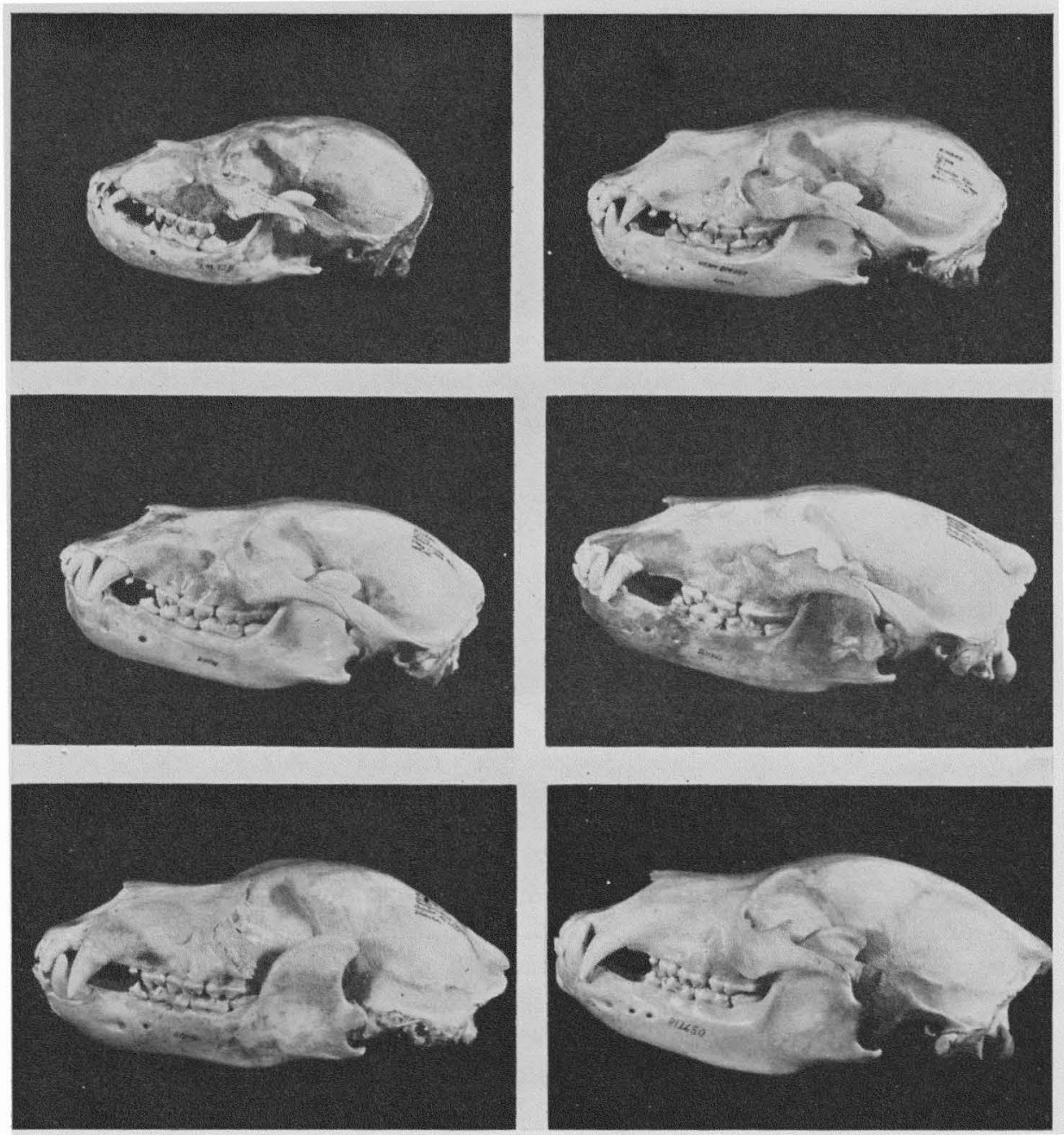

Fig. 4. Cranial changes associated with growth in $U$. arctos, from the Brooks Range. Probable ages are as follows, assuming January 1 as an average birth date (reading left to right from top): USNM292125 - 8 mos.; R10533 - 22 mos.; R11588 - 2 yrs. 4 mos. R11710 - 2 yrs. 7 mos.; R12018 - 3 yrs. 8 mos.; R12650 - 4 yrs. 9 mos. All photographed at same scale. Cranial measurements are given in Table I.

bility by later North American mammalogists. A broader view of speciation in bears has been taken by certain Old World workers. For example, Bobrinskiy et al. (1944) included North America in the range of $U$. arctos as defined by them. Ellerman and Morrison-Scott (1951) stated, regarding the range of $U$. arctos, that it occurs "Also in North America."

If my conclusions regarding individual variation in grizzlies prove valid, the structural characters (cranial) which have been considered adequate to differentiate $U$. arctos also have lessened importance. I have, unfortunately, not found it possible to study many specimens of $U$. arctos. Ellerman and Morrison-Scott (1951) considered valid 7 Old World subspecies of this species. 


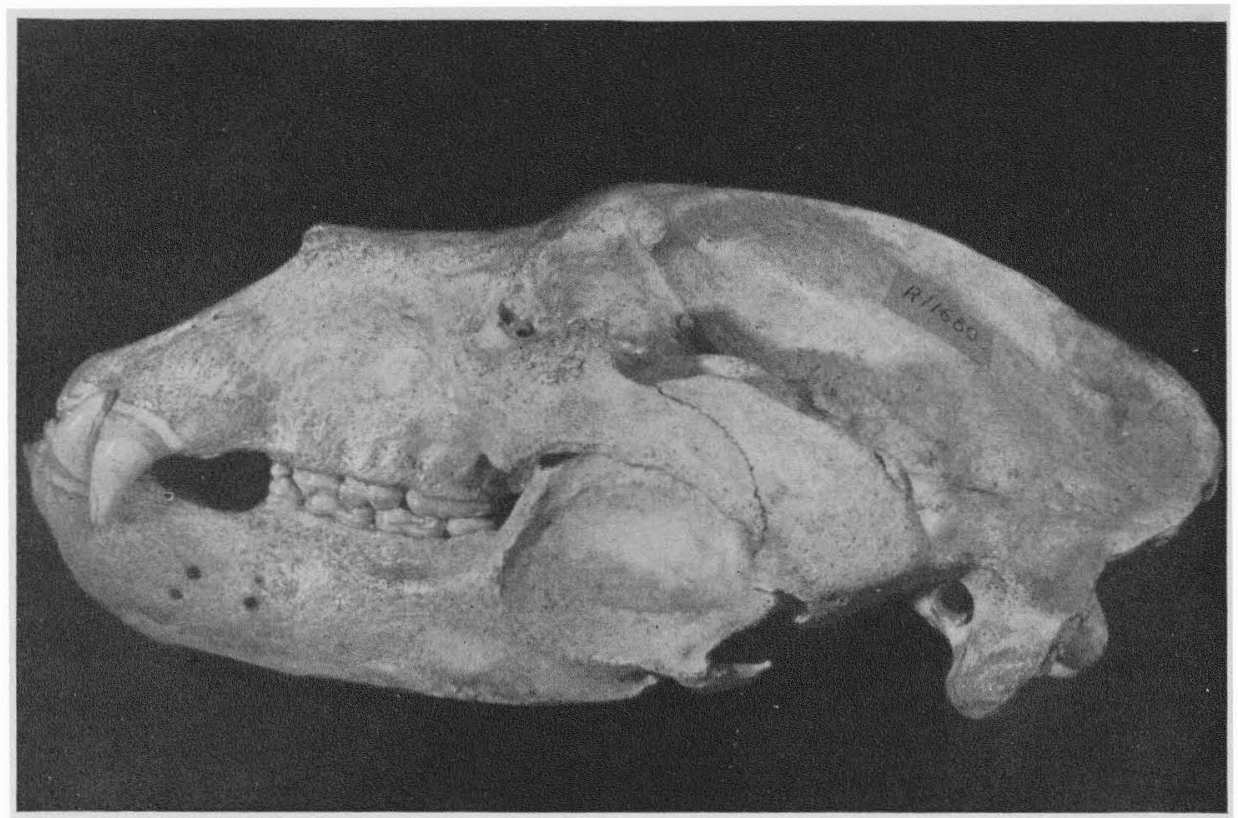

Fig. 5. Skull of old male $U$. arctos gyas, killed near Cold Bay, Alaska Peninsula. Measurements are given in Table $\mathbf{I}$.

Of these, I have examined skulls of only $U$. a. arctos Linnaeus, $U$. a. isabellinus Horsfeld, and $U$. a. pruinosus Blyth. Among these, a specimen of $U$. a. pruinosus from Tibet closely resembled some of the smaller Alaskan specimens. The range in size from the small $U$. a. isabellinus (India) to the great $U$. a. beringianus of northeast Siberia is greater than any size contrast of which I am aware in nearctic forms. J. A. Allen (1903b) compared skulls of $U$. $a$. beringianus with skulls of some North American bears. He stated: "Compared with skulls of Ursus middendorffi Merriam, from Kadiak Island, of corresponding age and sex, the breadth of the skull is much greater in proportion to its length, the anterior narial opening is much shorter, and the molars differ in relative size and form. It much more resembles in general contour and proportions the skull of the Barren Ground Bear (Ursus richardsoni), as perhaps should be expected." (pp. 164-5).

In my opinion there is no justification for considering North American grizzlies specifically distinct from Ursus arctos. It is necessary, however, to determine appropriate subspecific names in some cases.

Ursus horribilis Ord, 1815, appears to be the oldest available name for the grizzly. More conservative writers have recently used this name for all grizzlies, in view of the recognized unsuitability of Merriam's classification. Merriam obtained a topotype specimen which served for his characterization of this form (1918), but it is difficult to know how far the name borribilis can be applied. From Merriam's discussion, it is evident that he differentiated borribilis from forms he considered to be related on the basis of characters now known to be quite variable. In any event, the grizzly of the western 


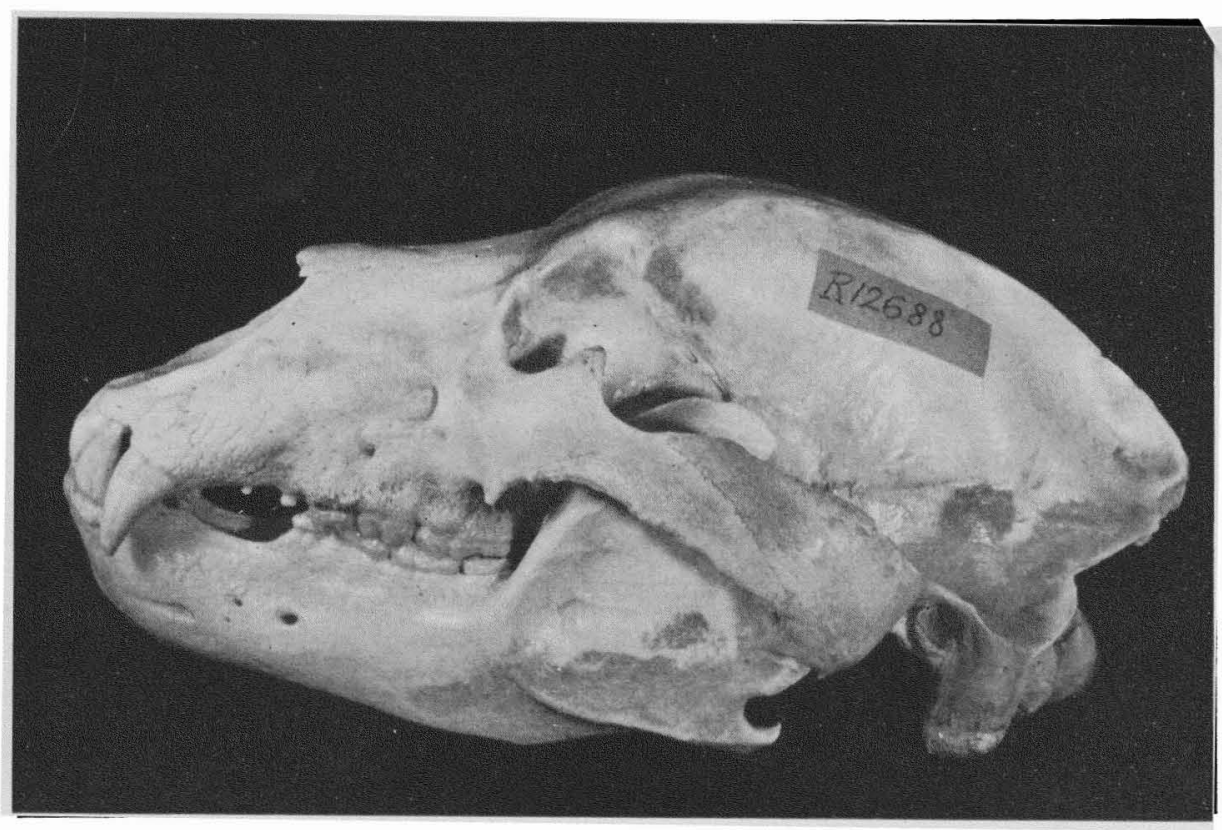

Fig. 6. Skull of old male U. arctos middendorffi, Kodiak Island. Measurements are given in Table $\mathrm{I}$.

United States may be called Ursus arctos horribilis Ord. The fact that Merriam included animals from as far north as Yakutat Bay and Admiralty Island, Alaska, in his "horribilis group" would indicate that the subspecific name horribilis can be applied safely to the form formerly ranging over the western United States and western Canada. The members of Merriam's "borribilis group" were differentiated on the basis of minor cranial differences; since he had very few specimens of some "species"-in some cases only one-available for study, individual variation could not have been taken into consideration.

It is not certain whether the name horribilis can also be applied to grizzlies occurring farther north in Alaska and northern Canada. Richardson (1829) designated tentatively as U. arctos americanus the barren-ground bear "killed on the shores of the Arctic Sea" during Franklin's first expedition in 1821. The name americanus is preoccupied by $U$. americanus Pallas, 1780, and cannot be applied here. This bear was later given the name $U$. richardsoni Swainson. At present, it seems best to use the name $U$. arctos horribilis for the grizzlies of northern Canada and mainland Alaska.

Because of its unusually large size, and the relative uniformity of certain cranial characters, it seems appropriate to consider the Alaska Peninsula bear a distinct subspecies. It may be designated $U$. arctos gyas Merriam. A typical skull, large adult male, is shown in Fig. 5. Although variants occur, a large form is predominant. Merriam (1918) described some of the variants of this form.

The bear found on Kodiak, Afognak, and Shuyak islands also may be considered a distinct race. This form differs from the Peninsula bear in having 
(in the adult male) a relatively great zygomatic width and a higher, more inflated cranium. Kodiak bears attain about the same maximum size as the Peninsula bears; however, breeding adults are not all of unusually large size. In June 1953 I weighed a breeding male which was killed while running with an adult female; this animal weighed $580 \mathrm{lbs}$. and measured $2123 \mathrm{~mm}$. in total length. A female killed the same week, with yearling cubs, weighed only 375 lbs., with a total length of $1782 \mathrm{~mm}$. These animals, of course, would have weighed considerably more in the fall of the year, since neither was fat.

This bear may be designated $U$. arctos middendorffi Merriam. A typical skull, adult male, is shown in Fig. 6.

In southern Alaska, large bears are occasionally killed which appear to be intergrades between the larger forms and the smaller bears of the mainland. These were considered specifically distinct by Merriam. Two of these from the Kenai Peninsula and Montague Island were designated as $U$. kenaiensis Merriam and $U$. sheldoni Merriam.

Some of the island species of southeastern Alaska have not been considered in this paper, mainly because I have not had adequate material for study. Merriam stated that the "species" of bears on islands often have their counterparts on the mainland of Alaska. On Admiralty Island, for example, Merriam concluded that five species exist together (shirasi, mirabilis, insularis, neglectus, and eulophus). He also listed five mainland species from which he considered the Admiralty Island forms to have been derived (dalli, stikeenensis, tabltanicus, kwakiutl, and caurinus). Merriam himself pointed out (1918) that the strait between Admiralty Island and the mainland is not more than five miles wide at the narrowest point. Grizzlies are powerful swimmers, and there can be little doubt that there has been a continual exchange of bears between the mainland and Admiralty Island, Merriam's island "species" being nothing more than individuals showing a normal (for bears) degree of variation. Although grizzlies show relatively great variation in cranial characters, the pattern of variation appears to be genetically restricted along certain definite lines. This may account for the fact that bears showing a given type of skull may occur almost anywhere within the range of the species. This situation might explain the "group" concept as defined by Merriam (1918). There is, however, a stronger tendency toward uniformity in some regions than in others. An interesting example of variation is shown by one of the Brooks Range specimens (Fig. 3, 11707), which resembles more closely a typical skull from Kodiak Island than it does any other Brooks Range specimens which I have seen. Conversely, skulls of some adult females and young males from Kodiak Island cannot be differentiated from skulls of bears from interior Alaska.

It is regrettable that predator control, excessive hunting, and the advances of civilization have exterminated the grizzly over the greater part of its original geographic range. Little can be learned of this interesting and important species in the United States and southern Canada except from early records (e.g., the journals of Lewis and Clark) and a few bones in museum collections.

A serious situation exists at present in Alaska, where the fishing interests and local cattlemen are attempting to bring about legislation which would 
permit uncontrolled killing of the bears on Kodiak Island. These animals, subjected annually to a heavy legal hunting pressure, are killed at all times on the slightest pretext by the cattlemen. If present regulations were relaxed, the extinction of this unique animal would be certain.

Ursus americanus Pallas. Black bear.

No further information has been obtained on the occurrence of the black bear in the Brooks Range. It is not found near Arctic Village, according to the Indians, but it is numerous near Christian Village, some forty-five miles to the south.

A large series of skulls from Alaskan black bears has been assembled, and it is evident that the species also shows much cranial variation. This work will be reported separately.

Vulpes vulpes alascensis Merriam. Alaska red fox.

Three red foxes were obtained in the vicinity of Arctic Village. None was seen in the Romanzof Mountains in 1951, and there was little sign of fox there. Skull measurements of 45 red foxes, the majority from the Brooks Range, are given in Table II.

Both Bobrinskiy et al. (1944) and Ellerman and Morrison-Scott (1951) (the latter on the authority of Pocock) regarded $V$. vulpes a species having circumpolar distribution. There does not appear to be any reason for disagreement with this concept, and the name Vulpes vulpes is consequently used here.

Alopex lagopus innuitus (Merriam). Continental arctic fox.

The irregular occurrence of this species in the Brooks Range has been reported (Rausch, 1951), and 2 specimens were obtained during the winter of 1951-2. A female arctic fox was trapped by Eskimo on 17 November 1951 on Itikmalukpuk Creek, northeast of Anaktuvuk Pass. According to cranial characteristics, this specimen was an adult. It weighed 2,800 grams. An adult male was killed on 9 March 1952, about six miles up the valley of the East Chandalar River, above Arctic Village. This was well within the taiga zonc. According to the natives, the arctic fox is sometimes common around the head of the river.

Arctic foxes were abundant along the Arctic Coast during the winter of 1952-3, and large numbers were trapped by the Eskimo of Barrow and Wainwright. The brown lemming attained a high level of population density in the summer of 1952, and a fox abundance is an expected consequence.

Canis Iupus ?tundrarum Miller. Wolf.

Wolves collected in northeastern Alaska are assigned to this form on the basis of locality. This is hardly satisfactory, but the study of available material has thrown some doubt on the validity of Alaskan subspecies of wolves as at present defined. It was evident, in comparing specimens of a large collection of wolf skulls, that considerable individual variation occurs.

1 The firm stand taken by Clarence Rhode, Director, Alaska Division, U.S. Fish and Wildlife Service, has been effective in preventing unrestricted killing of bears on Kodiak Island. 
Rausch in Arctic: Journal of the Arctic Institute of North America (July 1953) 6(2).

Copyright 1953, Arctic Institute of North America. Used by permission.

\begin{tabular}{|c|c|c|c|c|c|c|c|c|}
\hline Locality & $\operatorname{Sex}$ & $\begin{array}{c}\text { Condylo- } \\
\text { basal } \\
\text { length }\end{array}$ & $\begin{array}{l}\text { Zygo- } \\
\text { matic } \\
\text { widih }\end{array}$ & $\begin{array}{l}\text { Squamosal } \\
\text { constriction }\end{array}$ & $\begin{array}{l}\text { Inter- } \\
\text { orbilal } \\
\text { width }\end{array}$ & $\begin{array}{l}\text { Palatal } \\
\text { length }\end{array}$ & $\begin{array}{c}\text { Post- } \\
\text { palatal } \\
\text { length }\end{array}$ & $\begin{array}{c}\text { Maxillary } \\
\text { tcoth row } \\
\text { length }\end{array}$ \\
\hline Anaktuvuk Pass & O & 138.5 & 74.5 & 48.3 & 26.7 & 71.7 & 60.0 & 64.9 \\
\hline Anaktuvuk Pass & & 137.3 & 73.9 & 47.7 & 25.7 & 70.4 & 65.7 & 64.4 \\
\hline Anaktuvuk Pass & & 144.6 & 74.6 & 48.3 & 28.0 & 75.8 & 68.0 & 69.2 \\
\hline Anaktuvuk Pass & & 132.8 & 74.1 & 46.8 & 27.7 & 70.3 & 61.9 & 62.3 \\
\hline Chandler L. & & 137.4 & 72.4 & 47.2 & 27.6 & 74.5 & 61.9 & 64.4 \\
\hline Chandier 1. . & & 132.8 & 75.3 & 46.9 & 27.4 & 68.1 & 63.1 & 63.3 \\
\hline Chandler $\mathrm{L}$. & & 132,9 & 73.4 & 47.6 & 24.6 & 70.2 & 62.5 & 63.0 \\
\hline Okominilaga Cr. & & 133.5 & 73.3 & 47.3 & 28.8 & 68.5 & 64.3 & 63.9 \\
\hline Ipper John R. & & 138.2 & 74.2 & 45.6 & 26.0 & 71.0 & 65.9 & - \\
\hline Noatak R. & & 138.6 & 76.2 & 48.1 & 27.6 & 71.5 & 65.3 & 65.1 \\
\hline Wainwright & & 139.5 & 76.0 & 48.4 & 30.2 & 71.4 & 66.6 & 67.4 \\
\hline Wainwright & & 142.0 & 77.9 & 48.2 & 31.8 & 73.7 & 67.1 & 68.8 \\
\hline Wainwright & & 134.7 & 75.0 & 46.8 & 27.0 & 70.6 & 60.7 & 64.9 \\
\hline Arctic Village & & 138.5 & 72.7 & 47.7 & 26.5 & 72.2 & 6.5 .8 & 65.2 \\
\hline Arctic Village & & 141.7 & 78.8 & 47.6 & 27.3 & 73.4 & 66.2 & 66.5 \\
\hline Arctic Village & & 133.8 & 74.6 & 46.1 & 25.6 & 70.0 & 6.3 .0 & 65.0 \\
\hline Fort Yukon area & & 140.0 & 78.1 & 48.3 & 30.1 & 75.0 & 6.3 .3 & 65.8 \\
\hline Lake St. Ann & & 136.2 & 75.0 & 47.4 & 20.6 & 70.5 & 04.5 & 63.9 \\
\hline Copper Center & & 142.4 & 77.9 & 45.9 & 27.5 & 75.0 & 65.7 & 65.8 \\
\hline Tyone L. & & 142.1 & 78.8 & 47.5 & 20.5 & 75.1 & 66.7 & 67.5 \\
\hline Tyone I. & & 13.3 .4 & 71.7 & 45.7 & 30.0 & 69.2 & 62.5 & 57.8 \\
\hline Tyone 1. & & 130.2 & 71.1 & 46.2 & 26.1 & 68.7 & 60.6 & 60.5 \\
\hline Mi. 160. Glenn Hwy. & & 1.32 .8 & 73.4 & 45.9 & 28.8 & 69.1 & 63.0 & 62.9 \\
\hline Mi. 170. Glenn Hwy. & & 135.3 & 72.6 & 46.5 & 25.7 & 70.2 & 64.1 & 65.5 \\
\hline Anaktuvuk Pass & 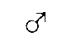 & 137.3 & 75.5 & 47.6 & 26.7 & 72.8 & 64.0 & 63.9 \\
\hline Anaktuvuk Pass & & 139.1 & 77.9 & 49.0 & 29.0 & 7.3 .8 & 63.7 & 67.5 \\
\hline Anaktuvuk Pass & & 148.6 & 81.9 & 48.2 & 29.5 & 79.8 & 60.8 & 69.7 \\
\hline Anaktuvuk Pass & & 142.0 & 78.5 & 49.0 & 26.5 & 72.5 & -- & 61.5 \\
\hline Asinak $\mathrm{I}$. & & 140.9 & 76.0 & 47.7 & 28.2 & 75.3 & 6.5 .5 & 67.1 \\
\hline Chandler $\mathrm{L}$. & & 142.2 & 77.9 & 48.3 & - & 72.1 & 67.8 & 66.1 \\
\hline Chandler $\mathrm{L}$. & & 137.1 & 76.3 & 47.8 & 27.8 & 67.9 & 67.0 & 64.5 \\
\hline Chandler $\mathbf{L}$. & & 142.3 & 82,0 & 48.5 & 33.6 & 7.5 .5 & 6.5 .7 & 68.2 \\
\hline Chandler $\mathrm{L}$. & & 140.1 & 77.4 & 49.1 & 20.7 & 72.4 & 6.5 .7 & 65.7 \\
\hline Wainwright & & 145.7 & 77.1 & 47.8 & 28.2 & 75.5 & 68.2 & 60.6 \\
\hline Wainwright & & 143.8 & 79.9 & 49. 8 & 28.7 & 74.9 & 67.3 & 68.0 \\
\hline Arctic Village & & 144.7 & 79.4 & 49.5 & 29.2 & 76.1 & 68.1 & 67.4 \\
\hline Arctic Village & & 138.3 & 78.2 & 47.5 & 29.3 & 73.6 & 63.2 & 65.4 \\
\hline Arctic Village & & 144.3 & 75.5 & 48.6 & 26.3 & 75.2 & 67.4 & 69.0 \\
\hline Arctic Village & & 138.4 & 69.5 & 46.0 & 24.7 & 73.6 & 63.2 & 65.9 \\
\hline Aretic Village & & 135.8 & 71.4 & 46.9 & 25.6 & 70.7 & 64.2 & 65.9 \\
\hline Aretic Village & & 146.1 & 79.8 & 47.9 & 28.3 & 77.4 & 67.5 & 68.7 \\
\hline Arctic Village & & 139.8 & 71.2 & 46.6 & 26.2 & 73.0 & 65.4 & 67.2 \\
\hline Copper Center & & 145.2 & 77.5 & 48.0 & 29.6 & 79.3 & 64.7 & 68.2 \\
\hline Tyone $\mathrm{L}$ & & 155.5 & 90.8 & 52,4 & 33.2 & 83.6 & 70.5 & 71.7 \\
\hline Mi. 170, Glenn Hwy. & & 139.9 & 79.9 & 48.6 & 31.4 & 71.6 & 66.5 & 68.2 \\
\hline Average & 99 & 137.05 & 74.81 & 47.16 & 27,49 & 71.50 & 64.43 & 64.69 \\
\hline Average & $\sigma^{x} \sigma^{x}$ & 142.24 & 77.79 & 48.32 & 28.58 & 74.60 & 66.13 & 67.39 \\
\hline
\end{tabular}

One wolf was collected near Lakc Schrader and 4 specimens were obtained from the Indians at Arctic Village. During May 1952 I was able to collect an adult male a few miles south of Point Barrow-approximately at the type locality of C. lupus tundrarum. In addition, a large series of skulls, with full collecting data, is at hand from the central Brooks Range. From this region about 150 wolves have been autopsied, but it has not been possible to preserve all of them for mammalogical studies.

Skull measurements for 48 wolves are given in Table III. Most of these are arctic specimens, but a few others have been included for comparative 
Rausch in Arctic: Journal of the Arctic Institute of North America (July 1953) 6(2).

Copyright 1953, Arctic Institute of North America. Used by permission.

ON THE STATUS OF SOME ARCTIC MAMMALS

Table III. Cranial measurements of 48 Alaskan wolves $^{1}$ (in millimetres).

\begin{tabular}{|c|c|c|c|c|c|c|c|c|c|c|}
\hline $\begin{array}{c}\text { Date } \\
\text { collected }\end{array}$ & Locality & Age & Sex & $\begin{array}{c}\text { Condylo- } \\
\text { basal } \\
\text { length }\end{array}$ & $\begin{array}{l}\text { Zygo- } \\
\text { matic } \\
\text { width }\end{array}$ & $\begin{array}{l}\text { Inter- } \\
\text { orbilal } \\
\text { width }\end{array}$ & $\begin{array}{l}\text { Palatal } \\
\text { length }\end{array}$ & $\begin{array}{l}\text { Post- } \\
\text { palatal } \\
\text { length }\end{array}$ & $\begin{array}{l}\text { Squamosal } \\
\text { constric* } \\
\text { tion }\end{array}$ & $\begin{array}{c}\text { Maxillary } \\
\text { tooth row } \\
\text { length }\end{array}$ \\
\hline \multicolumn{11}{|l|}{ Group 1} \\
\hline Fall '51 & Point Lay & $\begin{array}{l}\text { approx. } \\
6 \text { mos. }\end{array}$ & ㅇ & 220.9 & 122.8 & 44.1 & - & - & 77.2 & 99.2 \\
\hline $8 / 1 / 52$ & Itikmalukpuk $\mathrm{Cr}$. & 8 mos. & & 215.9 & 114.2 & 39.2 & 114.8 & 98.9 & 73.2 & 100.7 \\
\hline $11 / 1 / 52$ & Anaktuvuk Pass & 8 mos. & & 236.1 & 131.1 & 43.1 & 123.8 & 110.2 & 80.8 & 107.2 \\
\hline $1 / 2 / 52$ & Chandler L. & 9 mos. & & 221.8 & 124.3 & 39.4 & 118.4 & 102.4 & 75.2 & 100.8 \\
\hline $6 / 2 / 52$ & Arctic Village & 9 mos. & & 223.3 & 121.4 & 41.6 & 117.0 & 105.7 & 79.0 & 101.9 \\
\hline $4 / 3 / 51$ & Anaktuvuk Pass & 10 mos. & & 231.4 & 127.6 & 45.8 & 122.6 & 108.4 & 78.5 & 104.7 \\
\hline $2 / 7 / 51$ & Lake Schrader & adult & & $\longrightarrow$ & 135.0 & 46.0 & - & - & - & 107.0 \\
\hline $21 / 4 / 51$ & Anaktuvuk Pass & adult & & 209.0 & 130.4 & 46.0 & - & 一 & 81.0 & 113.3 \\
\hline 14/ $2 / 51$ & Anaktuvuk Pass & adult & & 232.6 & 133.9 & 49.6 & 119.5 & 111.5 & 78.6 & 106.3 \\
\hline Winter '51 & Anaktuvuk Pass & adult & & 234.4 & 138.1 & 45.9 & 121.3 & 111.5 & 77.7 & 105.2 \\
\hline 1951 & Anaktuvuk Pass & adult & & 238.3 & 130.9 & 43.3 & 125.9 & 111.7 & 79.7 & 106.9 \\
\hline $4 / 4 / 52$ & Ikiakpuk Cr. & adult & & 254.7 & 148.9 & 52.4 & 134.2 & 117.8 & 84.1 & 116.3 \\
\hline $1 / 4 / 52$ & Anaktuvuk Pass & adult & & 256.5 & 133.3 & 42.0 & 137.5 & 117.9 & 79.9 & 118.3 \\
\hline $4 / 4 / 51$ & Anaktuvuk Pass & adult & & 258.0 & 139.3 & 46.9 & 130.0 & 124.7 & 85.0 & 114.1 \\
\hline $1 / 4 / 52$ & Anaktuvuk Pass & old adult & & 228.1 & 135.6 & 46.9 & 121.4 & 105.3 & 78.5 & - \\
\hline $13 / 9 / 51$ & Arctic Village & old adult & & 229.3 & 137.0 & 48.4 & 120.5 & 107.8 & 81.6 & 103.4 \\
\hline 4/ $2 / 52$ & Arctic Village & old aduit & & 236.6 & 136.3 & 44.7 & 124.9 & 111.1 & 77.9 & 105.7 \\
\hline $14 / 1 / 52$ & Anaktuvuk Pass & old adult & & 242.1 & 134.3 & 44.4 & 130.1 & - & 80.9 & 108.9 \\
\hline $26 / 3 / 52$ & Tulugak L. & old adult & & 242.8 & 136.8 & 44.9 & 131.1 & 112.0 & 81.7 & 106.7 \\
\hline $15 / 11 / 51$ & Anaktuvuk Pass & old adult & & 256.7 & 139.1 & 51.7 & 135.1 & 118.9 & 82.3 & 116.5 \\
\hline $28 / 10 / 51$ & Tulugak I.. & 5 mos. & $\sigma^{2}$ & 237.6 & 125.3 & 41.7 & 125.8 & 109.8 & 81.4 & 107.6 \\
\hline $19 / 12 / 51$ & Head, Hunt Fork & 7 mos. & & 216.3 & 125.7 & 40.9 & 113.8 & 100.9 & 75.8 & 98.5 \\
\hline $12 / 12 / 51$ & Killik R. & 7 mos. & & 216.4 & 127.3 & 40.8 & 115.5 & 100.0 & 74.0 & 98.7 \\
\hline $26 / 1 / 52$ & Anaktuvuk Pass & 8 mos. & & 226.8 & 126.6 & 42.3 & 120.0 & - & 79.8 & 101.5 \\
\hline $6 / 3 / 52$ & Anaktuvuk Pass & $10 \mathrm{mos}$. & & 231.7 & 125.0 & 42.6 & 122.8 & 108.3 & 77.7 & 108.0 \\
\hline $19 / 12 / 49$ & lkiakpuk $\mathrm{Cr}$. & adult & & 230.0 & 132.5 & 45.5 & - & - & 79.0 & 107.0 \\
\hline $6 / 1 / 50$ & Anaktuvuk Pass & adult & & 227.0 & 123.0 & 44.0 & -. & - & 77.5 & 99.5 \\
\hline $16 / 3 / 52$ & John R. & adult & & 237.1 & 132.2 & 45.9 & 128.9 & 108.0 & 77.3 & 108.3 \\
\hline $4 / 4 / 51$ & Anaktuvuk Pass & adult & & 237.3 & 131.5 & 42.7 & 125.0 & 111.8 & 77.7 & 106.7 \\
\hline $9 / 6 / 52$ & $60 \mathrm{mi} . \mathrm{S}$. Barrow & adult & & 241.8 & 144.6 & 47.1 & 130.0 & 110.7 & 81.8 & 109.7 \\
\hline Winter' 52 & 2 Anaktuvuk Pass & adult & & 242.3 & 133.1 & 45.3 & 126.3 & 114.0 & 78.4 & 108.9 \\
\hline $5 / 4 / 52$ & Anaktuvuk Pass & adult & & 242.7 & 133.8 & 49.5 & 126.5 & 114.9 & 78.7 & 111.3 \\
\hline $3 / 4 / 51$ & Itikmalukpuk Cr. & adult & & 242.7 & 131.3 & 45.5 & 127.0 & 114.4 & 82.1 & 107.0 \\
\hline $11 / 1 / 52$ & Chandler L. & old adult & & 233.7 & 124.0 & 42.5 & 121.4 & 110.8 & 78.4 & 105.5 \\
\hline Winter ' 52 & 2 Anaktuvuk Pass & old adult & & 239.4 & 149.7 & 48.6 & 122,7 & 114.5 & 84.0 & - \\
\hline $1 / 2 / 52$ & Chandler $\mathrm{L}$. & old adult & & 246.4 & 148.2 & 49.0 & 131.0 & 114.2 & 83.0 & 110.3 \\
\hline $23 / 10 / 51$ & Anaktuvuk Pass & old adult & & 250.1 & 151.8 & 54.5 & 131.7 & 116.9 & 84.2 & 110.9 \\
\hline Dec. 51 & Tulugak L. & old adult & & 253.5 & 148.8 & 52.9 & 131.1 & 119.3 & 81.3 & - \\
\hline $6 / 3 / 52$ & Arctic Village & old adult & & 257.1 & 152.6 & 48.3 & 132.6 & 123.3 & 84.7 & 111.4 \\
\hline $12 / 12 / 51$ & Anaktuvuk Pass & old adult & & 264.2 & 144.7 & 49.5 & 138.7 & 123.9 & 79.8 & - \\
\hline \multicolumn{11}{|l|}{ Group 2} \\
\hline $25 / 3 / 50$ & Tonsina L. & adult & $q$ & 226.7 & 132.5 & 43.4 & 110.3 & 110.0 & 77.6 & 104.0 \\
\hline $5 / 4 / 52$ & Clarence L.. & adult & & 247.9 & 148.5 & 50.0 & 132.9 & 113.4 & 83.7 & 113.4 \\
\hline Feb. '50 & Gulkana & old adult & & 237.6 & 135.8 & 46.1 & 126.0 & 109.8 & 77.4 & 106.5 \\
\hline Oct. ' 51 & Venetie $^{2}$ & 5 mos. & $\sigma^{7}$ & 224.2 & 113.9 & 38.7 & 116.9 & 103.2 & 75.4 & - \\
\hline Feb.' 50 & Gulkana & 9 mos. & & 235.4 & 130.2 & 45.9 & 122.0 & 111.6 & 78.7 & 105.9 \\
\hline Mar. '51 & Gulkana & adult & & 246.2 & 137.2 & 44.9 & 131.0 & 113.0 & 86.7 & 110.4 \\
\hline $5 / 4 / 52$ & Clarence $\mathbf{L}$. & adult & & 266.0 & 147.9 & 51.4 & 140.2 & 123.0 & 82.2 & 120.9 \\
\hline \multicolumn{11}{|l|}{ Group 3} \\
\hline $15 / 2 / 51$ & $\begin{array}{c}\text { Tustumena L., } \\
\text { Kenai Pen. }\end{array}$ & aduIt & $\sigma^{x}$ & 254.7 & 150.3 & 51.1 & 135.0 & 118.5 & 84.3 & 113.2 \\
\hline
\end{tabular}

purposes. Age designations are given as accurately as possible. The age of young animals was computed by assuming a birth date of May 15 . The date 
of killing was known for all specimens. Comparisons of the skulls of young animals were also made with the skull of a captive male wolf which was five months old at the time of death (assuming the May 15 birth date).

Material from which C. lupus tundrarum was characterized (Miller, 1912) comprised specimens from widely separated localities. Young and Goldman (1944) summarized available data on North American wolves. Goldman prepared the taxonomic section, and had for study only 9 skulls of $C$. lupus tundrarum; of these, 5 were topotypes. Anderson (1943) studied 6 topotype specimens. Canis lupus tundrarum is differentiated as follows from forms with adjacent ranges (after Young and Goldman, 1944):

"Closely allied to pambasileus of Mount McKinley region, but color paler and grayer, the white less mixed with brown or buff on head, and back more sparingly overlaid with black; skull with heavier dentition. Similar also to occidentalis and mackenzii of Mackenzie in size, but color darker, the general dorsal area more extensively mixed with black, and the tendency toward pure white less evident than in occidentalis; dentition heavier." (p. 417).

The study of 40 skulls designated as C. lupus tundrarum (Table III) has made possible some understanding of normal variation. The largest skull I examined was but $4 \mathrm{~mm}$. shorter in condylo-basal length than the largest specimen of C. lupus pambasileus recorded from Alaska by Young and Goldman. It exceeded in size the skulls of two adult $C$. lupus alces Goldman (1941), as well as that of an adult male of the same form in my possession. I do not recognize that C. lupus tundrarum can be differentiated from C. lupus pambasileus on the basis of heavier dentition. Brooks Range and Arctic Coast wolves exhibit a wide range of variation in tooth size. A few animals show very light, relatively small teeth, while a few have a dentition more massive than average.

I doubt that colour in Alaskan wolves has any taxonomic significance. There is a wide range in colour, from nearly white to almost black, but animals of either extreme and all intermediate colours may occur in any given region. Some wolves appear white from a distance, but all that I have seen close at hand have had some black-tipped hairs dorsally. The most nearly white specimen that I have seen, an adult male trapped by Eskimo near Anaktuvuk Pass, has been deposited in the collections of the U.S. National Museum (No. 294404). About half of all wolves killed or observed in the Brooks Range approach black in colour. Miller (1912) stated that the colour of C. lupus tundrarum is "said to be frequently white or whitish." It is likely, however, that he had some white specimens from the Canadian Arctic among the material he studied. Young and Goldman (1944) differentiated C. lupus tundrarum from C. lupus occidentalis Richardson and C. lupus mackenzii Anderson essentially on the basis of colour.

Restudy of the various subspecies of wolves secms necessary to determine whether the existence of so many named forms is justified. A series of each large enough to demonstrate normal individual variation is required. I doubt that C. lupus tundrarum can be differentiated from C. lupus pambasileus. The validity of C. lupus alces is also open to question. Wolves are very rare on 
the Kenai Peninsula, and it might be expected that animals from farther north move into this region from time to time. In any event, clear-cut ranges cannot be established for subspecies of a mammal as capable of movement over great distances as is the wolf.

In order to obtain adequate material from Alaska and northern Canada it will be necessary to enlist the aid of local trappers. It is particularly regrettable that the great numbers of wolves killed by the predator-control activities of the U.S. Fish and Wildlife Service in Alaska are not being utilized for scientific purposes.

U.S. Fish and Wildlife Service methods for wolf control appear to be effective under arctic conditions. During the winter of 1951-2 wolves in northern Alaska attained a very high population density-quite possibly the highest ever observed for this region. The Eskimo of the Anaktuvuk Pass region killed 160 wolves by combined trapping and shooting. U.S. Fish and Wildlife Service predator control men killed over 200 in the same region of the Brooks Range and farther north on the Arctic Slope between Umiat and the mountains. Since much of the predator control activities centred in the hunting grounds of the Eskimo, the latter felt keenly the competition offered, and although they had killed a large number of wolves prior to the predator control activities, they killed none afterward.

Wolves are known to fluctuate greatly in numbers in arctic Alaska (see Rausch, 1951), and it seems questionable whether the high cost of wolf destruction would make a control program practicable even if it were considered biologically sound. It is of interest to the biologist that large numbers of ground squirrels, at least one grizzly, some caribou, and at least 9 sledge dogs succumbed to the effect of strychnine-poisoned baits used for wolf control in the Anaktuvuk Pass region. The question comes up whether this type of control might not result in a higher residual population of wolves, since the natural transmission of disease might be minimized in a population of already greatly lessened density. With the great wolf density of 1951-2 epizootic disease broke out which no doubt would have had violent effect on their numbers, had man not intervened with other controls. Rabies appeared among them, as was the case during the last time of high population density in 1944-5 (see Rausch, 1951). This was confirmed by rabies virus recovery ${ }^{1}$ from the brain of a wolf killed while attacking tethered sledge dogs in an Eskimo camp. Rabies still occurred in foxes and dogs in eastern Alaska at the time of writing (December 1952).2

More serious was distemper, which broke out in epizootic proportions over all of arctic Alaska. Sledge dogs at Barrow, Wainwright, Point Lay, Anaktuvuk Pass, and in a camp along the lower John River, suffered greatly from this disease. About 500 dogs died at Barrow alone, and losses in other villages

${ }^{1}$ Rabies virus was recovered by the Virus and Rickettsia Section, Communicable Disease Center, Montgomery, Alabama.

'Foxes appear to be particularly important in the transmission of rabies. This is most obvious in highly developed regions (e.g., eastern and southcastern United States) where wolves no longer exist. 
were of similar proportion. Arctic foxes died along the coast, and there is little doubt that the disease was disseminated through the wild canine populations from the coast to the dogs of the Inland Eskimo, and on southward. Since the wolves comprised a population highly susceptible to distemper, losses among them could be expected to be heavy. Distemper appeared in dogs in the Brooks Range in the spring and summer, after the predator-control program of early spring.

Martes americana actuosa (Osgood). Alaska marten.

In the previous work on Brooks Range mammals, it was remarked (Rausch, 1951) that the single marten collected differed rather strikingly in colour from specimens from other localities farther south. Two additional specimens from northeastern Alaska have been obtained, and these agree closely in colour with the animal collected to the west. These marten were trapped by Indians about thirty miles northeast of Arctic Village. Two skulls without skins were also obtained. Table IV compares measurements of Brooks Range martens with

\begin{tabular}{|c|c|c|c|c|c|c|c|c|c|}
\hline Localily & Sex & $\begin{array}{c}\text { Condylo- } \\
\text { basal } \\
\text { length }\end{array}$ & $\begin{array}{l}\text { Zygo- } \\
\text { matic- } \\
\text { width }\end{array}$ & $\begin{array}{l}\text { Inter- } \\
\text { orbital } \\
\text { width }\end{array}$ & $\begin{array}{l}\text { Post- } \\
\text { orbital } \\
\text { width }\end{array}$ & $\begin{array}{c}\text { Mastoid } \\
\text { width }\end{array}$ & $\begin{array}{c}\text { Palatal } \\
\text { length }\end{array}$ & $\begin{array}{l}\text { Post- } \\
\text { palalal } \\
\text { length }\end{array}$ & $\begin{array}{c}\text { Maxillary } \\
\text { tooth row } \\
\text { length }\end{array}$ \\
\hline Arctic Village & q & 79.3 & 42.2 & 17.7 & 17.0 & 35.1 & 38.6 & 39.4 & 28.1 \\
\hline Arctic Village & & 78.4 & 40.8 & 16.5 & 17.2 & 34.4 & 39.0 & 38.6 & 28.1 \\
\hline Fort Yukon & & 81.4 & 47.0 & 18.5 & 15.5 & 36.8 & 39.8 & 39.8 & 29,4 \\
\hline Fort Yukon & & - & 43.7 & 16.6 & 16.5 & 35.4 & 38.7 & - & 28.5 \\
\hline Tyone L. & & 77.4 & 44.0 & 17.4 & 16.7 & 34.8 & 37.1 & 39.0 & 27.6 \\
\hline Mi. 160, Glenn Hwy & & 75.5 & 42.0 & 16.4 & 17.2 & 34.8 & 37.1 & 37.3 & 27.1 \\
\hline Hunt Fork & $\sigma^{7}$ & 85.5 & 45.0 & - & 17.5 & - & 42.0 & - & - \\
\hline Arctic Village & & 8.3 .6 & 51.3 & 19.0 & 15.2 & 38.9 & 40.5 & 41.9 & 29.6 \\
\hline Arctic Village & & 82.2 & 46.8 & 18.9 & 18.6 & 38.4 & 41.4 & 39.6 & 30.0 \\
\hline Fort Yukon & & 86.2 & 45.2 & 19.0 & 17.0 & 37.8 & 42.9 & 42.0 & 30.6 \\
\hline Fort Yukon & & 85.8 & 44.9 & 19.0 & 17.0 & 37.6 & 42.4 & 41.9 & 30.8 \\
\hline Fort Yukon & & 85.0 & 52.6 & 18.7 & 14.3 & 37.6 & 41.5 & 42.1 & 30.2 \\
\hline Tyone L. & & 84.7 & 53.1 & 20.0 & 16.6 & 39.0 & 41.3 & 41.8 & 30.5 \\
\hline Tyone I. & & 84.3 & 45.0 & 18.2 & 17.1 & 36.5 & 40.5 & 42.8 & 29.5 \\
\hline Tyone L. & & 83.5 & 44.9 & 18.0 & 17.2 & 37.2 & 41.7 & 40.6 & 30.2 \\
\hline Lake St. Ann & & 85.3 & 47.0 & 18.7 & 18.3 & 38.2 & 42.2 & 41.3 & 30.2 \\
\hline Skwentna & & 86.0 & 48.0 & 20.0 & 16.5 & 38.1 & 43.7 & 39.7 & 32.0 \\
\hline Average & 우우 & 78.4 & 43.28 & 17.18 & 16.68 & 35.21 & 38.38 & 38.82 & 28.13 \\
\hline Average & $\delta^{7} \sigma^{x}$ & 84.6 & 47.61 & 18.95 & 16.94 & 37.93 & 41.82 & 41.39 & 30.36 \\
\hline
\end{tabular}

those from Fort Yukon (topotypes of $M$. americana actuosa) and farther south. No significant differences were recognized. Lampio (1951) found that the size of Martes martes $\mathrm{L}$. in Finland increases northward, with maximum average size correlated with the lowest mean annual temperature. There is at present not enough available information to determine whether a similar situation exists in Alaska.

Preble (1908) discussed the characteristics of marten from the Mackenzie Delta region, and considered them identical with topotype specimens of $M$. americana actuosa. Coues (1877) has discussed the relationships of $M$. americana and related Eurasian species. 
Mustela erminea arctica (Merriam). Ermine.

More than 60 ermine, most of them in winter pelage, have been obtained from various localities in the Brooks Range. The largest series came from the Anaktuvuk Pass region, but a large series was also secured at Arctic Village. I observed 3 ermine around a den along the shore of Lake Schrader during the summer of 1951 , but did not take these specimens.

Since this weasel has recently been considered in detail by Hall (1951b), there is no need to include detailed measurements here. Large adult males from near Anaktuvuk Pass exceeded in average size the measurements given by Hall. Four specimens measured as follows: total length $340 \mathrm{~mm}$. (319-353); tail length $83 \mathrm{~mm}$. (82-90); hind foot length $49 \mathrm{~mm}$. (46-53). A large male I collected on 31 May 1949, in the central Brooks Range, weighed 285.5 grams. Hall did not give any weight for an adult specimen.

After the study of pertinent Eurasian and North American material, Coues (1877) concluded that "The ermines of Europe, Asia, and America are specifically identical." The work of later investigators has substantiated Coues's conclusion. M. erminea arctica of Alaska and arctic Canada occurs also on Kamchatka, according to Ognev (1935), Bobrinskiy et al. (1944), and Ellerman and Morrison-Scott (1951). Hall (1944), on the basis of 9 skulls, differentiated the Kamchatka form as M. erminea digna Hall, 1944, and maintained this opinion in his recent review (1951b). It is clear that the Kamchatka form is closely related to $M$. erminea arctica, but additional work, based on an adequate series of specimens, seems necessary to determine their relationship.

Mustela rixosa eskimo (Stone). Least weasel.

A single subspecies of least weasel, $M$. rixosa eskimo, occurs in Alaska according to Hall (1951b). Four Brooks Range specimens were identified earlier as $M$. rixosa rixosa (Bangs) (see Rausch, 1951). There seems to be no reason to question Hall's conclusion, although he had no Brooks Range specimens for comparative study. Nevertheless, the few specimens I have do not show the broader, larger skull of $M$. rixosa eskimo; they also average smaller in external measurements. Such characteristics are in part correlated with age.

Little additional information has been obtained on this species in arctic Alaska. I have heard from the Eskimo that it sometimes becomes common along the Arctic Coast during times of high density of Microtus populations, but I have not observed this. No specimens were obtained in northeastern Alaska.

Allen (1903b) apparently was the first to point out that $M$. rixosa is a circumpolar species. He differentiated it from $M$. nivalis Linnaeus on the basis of external characters, including size. However, Bobrinskiy et al. (1944) and Ellerman and Morrison-Scott (1951) regarded $M$. rixosa as a synonym of M. nivalis. Hall (1951b) did not agree with this concept. Further work is needed to establish whether $M$. nivalis occurs in North America, or whether the Siberian races now attributed to it are actually subspecies of $M$. rixosa. It seems expedient to adopt Hall's concept for the present time, although it is possible that it is too restricted. 
Mustela vison Schreber. Mink.

Although it was reported that mink occasionally occur in the Brooks Range (Rausch, 1951), no additional information has been obtained. I have secured a good series of mink from the vicinity of Fort Yukon, but have no specimens from farther north. The Arctic Village people know nothing of the occurrence of the mink in the eastern Brooks Range.

Lutra canadensis (Schreber). Otter.

Otter are frequently trapped about thirty miles south of Arctic Village, but the Indians have no knowledge of its occurrence in the mountains. It is apparently uncommon so far north, even though the taiga extends much farther in this region.

Gulo gulo luscus (Linnaeus). Wolverine.

A single wolverine, not collected, was observed near Lake Schrader in the Romanzof Mountains. Seven specimens were obtained near Arctic Village, 2 having been trapped some twenty-five miles to the east. Skull measurements and other data for a large series of Alaskan wolverine are given in Table $V$. Many of these specimens were collected in the Brooks Range.

Coues $(1877$, p. 43$)$ in reference to the wolverine, stated: "The identity of the animals of the two continents is to be considered fairly established, whatever range of variation in size and color either may present." The work of Degerb $\phi 1$ and Freuchen (1935), who also concluded that the North American and Eurasian wolverines are conspecific, was briefly discussed in another paper (Rausch, 1951). Bobrinskiy et al. (1944), with whom Ellerman and Morrison-Scott (1951) agreed, considered the wolverine a species having circumpolar distribution.

I have been able to obtain for study but a single skull of Gulo gulo, from the upper Lyapin river, northern Ural Mountains. Comparisons with a series of 41 skulls of Alaskan wolverine now in my possession has disclosed no appreciable differences. The work of Degerb $\phi 1$ and Freuchen was particularly thorough, however. It is evident that the species is highly variable in regard to skull characters. I agree with the above-mentioned workers that the name Gulo luscus should be considered a synonym of Gulo gulo Linnaeus.

In 1905 Elliot described Gulo bylaeus from the upper Susitna River, Mount McKinley region of Alaska. Through the courtesy of Colin C. Sanborn, Curator of Mammals, Chicago Natural History Museum, I have available for study 4 topotype specimens. This species was differentiated on the basis of presumed colour differences, and minor cranial differences (relatively narrow skull with unusually large auditory bullae). The study of all material indicated that the skull differences fall within the range of normal variation. Colour in North American wolverine, at least in Alaska, has no specific value. I have seen striking variation in the colour of Alaskan animals from the same locality, as mentioned earlier (Rausch, 1951). I conclude, therefore, that Gulo bylaeus Elliott, 1905, is a synonym of Gulo gulo luscus Linnaeus.

The measurements of 4 of Elliot's specimens are included in Table $\mathrm{V}$. Data on reproduction and certain growth changes in the wolverine will be 
Table V. Cranial measurements of 41 Alaskan wolverine (in millimetres).

\begin{tabular}{|c|c|c|c|c|c|c|c|c|}
\hline Locality & Date & Sex & $\begin{array}{c}\text { Condylo- } \\
\text { basal } \\
\text { length }\end{array}$ & $\begin{array}{l}\text { Zygo- } \\
\text { matic } \\
\text { width }\end{array}$ & $\begin{array}{l}\text { Squamosal } \\
\text { constriction }\end{array}$ & $\begin{array}{l}\text { Inter- } \\
\text { orbital } \\
\text { zeidith }\end{array}$ & $\begin{array}{l}\text { Palatal } \\
\text { length }\end{array}$ & $\begin{array}{c}\text { Maxillary } \\
\text { tooth row } \\
\text { lengih }\end{array}$ \\
\hline Anaktuvuk Pass & $10 / 1 / 51$ & $q$ & 133.0 & 94.5 & 72.0 & 39.0 & - & 49.0 \\
\hline Hunt Fork & $7 / 2 / 51$ & & 133.3 & 89.8 & 67.3 & -- & 69.8 & 48.8 \\
\hline Arctic Village & 11/ $1 / 51$ & & 132.3 & 97.6 & 72.0 & 39.4 & 68.0 & 49.0 \\
\hline Arctic Village & $21 / 3 / 52$ & & 138.0 & 97.0 & - & 39.0 & 69.0 & - \\
\hline Mi. 31, Tok Rd. & Jan. 50 & & 139.3 & 99.6 & 70.8 & 38.5 & 72.5 & 53.0 \\
\hline Mi. 170, Glenn Hwy. & $25 / 1 / 50$ & & 133.0 & 93.0 & 69.0 & 36.5 & 69.0 & 50.3 \\
\hline Chitina & Jan. 50 & & 129.0 & 90.5 & 68.6 & 37.1 & 65.6 & 46.6 \\
\hline Skwentna & $12 / 2 / 53$ & & 138.7 & 99.2 & 75.0 & 39.4 & 71.7 & 52.7 \\
\hline Skwentna & $26 / 1 / 53$ & & 134.8 & 96.5 & 73.7 & 36.0 & 69.9 & 49.8 \\
\hline Skwentna & $25 / 1 / 53$ & & 134.8 & 95.2 & 70.7 & 36.5 & 69.1 & 50.6 \\
\hline Anaktuvuk Pass & $17 / 12 / 48$ & का & 144.5 & 103.4 & 80.7 & 42.6 & - & 51.5 \\
\hline Anaktuvuk Pass & Winter 48 & & 147.5 & 107.5 & 76.1 & 42.5 & $-\cdots$ & 54.9 \\
\hline Anaktuvuk Pass & Feb. 50 & & 145.0 & 106.5 & 71.4 & 40.0 & 76.2 & 53.4 \\
\hline Anaktuvuk Pass & Feb. '50 & & 143.5 & 103.0 & 75.3 & 38.2 & 75.4 & 54.6 \\
\hline Anaktuvuk Pass & $28 / 2 / 52$ & & 151.2 & 109.6 & 83.5 & 44.5 & 76.6 & 52.5 \\
\hline Anaktuvuk Pass & $25 / 3 / 52$ & & 151.7 & 107.0 & 83.0 & 44.0 & 76.9 & 54.6 \\
\hline Anaktuvuk Pass & $4 / 4 / 52$ & & 138.6 & 108.2 & 81.9 & 46.7 & 69.1 & 50.3 \\
\hline Upper John R. & Winter ' 48 & & 141.6 & 101.0 & 78.0 & 38.6 & $-\cdots-$ & 51.9 \\
\hline Upper John R. & $3 / 1 / 49$ & & 140.7 & 101.2 & 77.0 & 38.6 & - & 51.3 \\
\hline Upper John $\mathbf{R}$. & $7 / 3 / 49$ & & 143.7 & 105.1 & 80.6 & 43.4 & -. & 52.0 \\
\hline Head, John R. & $19 / 1 / 52$ & & 144.8 & 105.6 & 81,9 & 40.6 & 76.3 & 51.6 \\
\hline Head, John R. & $21 / 2 / 52$ & & 143.0 & 103.3 & 80.0 & 39.5 & 73.0 & 54.7 \\
\hline Upper Hunt Fork & $10 / 12 / 51$ & & 144.0 & 107.0 & 78.4 & 40.5 & -- & 51.5 \\
\hline Kalutagiak $\mathrm{Cr}$. & $9 / 2 / 51$ & & 137.2 & 105.0 & 77.5 & 41.5 & 72.6 & 52.0 \\
\hline Arctic Village & $28 / 10 / 51$ & & 143.4 & 104.2 & 一 & 40.5 & 74.3 & 54.6 \\
\hline Arctic Village & $1 / 11 / 51$ & & 148.0 & 101.6 & 76.6 & 40.3 & 75.0 & 55.2 \\
\hline Arctic Village & $28 / 2 / 52$ & & 144.0 & 100.5 & 76.7 & 39.4 & 75.5 & 53.0 \\
\hline Arctic Vi!lage & $1 / 11 / 51$ & & 142.4 & 102.5 & 76.8 & 40.5 & 72.5 & 52.1 \\
\hline Arctic Village & $6 / 1 / 52$ & & 143.6 & 108.1 & 83.2 & 39.5 & 74.5 & 53.8 \\
\hline Arctic Village & $1 / 11 / 51$ & & 150.5 & 108.4 & 82.2 & 42.8 & 78.7 & 55.7 \\
\hline Snake R., $17 \mathrm{mi}$. Nome & $11 / 12 / 52$ & & 145.5 & 99.9 & 75.9 & 30.7 & 72.7 & 53.3 \\
\hline Mi. 31, Tok Rd. & Jan. '50 & & -- & 111.8 & - & 40.8 & 78.2 & 55.0 \\
\hline Mi. 180, Glenn Hwy. & Apr. 51 & & 149.0 & 103.1 & 75.9 & 43.0 & 78.8 & 55.6 \\
\hline Skwentna & $25 / 1 / 53$ & & 152.8 & 105.1 & - & 40.5 & 78.6 & 55.5 \\
\hline Talkeetna Mts. & $27 / 12 / 51$ & & - & 105.3 & 79.5 & 40.0 & 78.0 & 54.4 \\
\hline Talkeetna Mts.' & $22 / 7 / 52$ & & 143.8 & 95.0 & 72.4 & 38.8 & 71.8 & - \\
\hline Susitna Valley $\mathbf{y}^{2}$ & $4 / 2 / 53$ & & - & - & - & - & - & - \\
\hline \multicolumn{2}{|l|}{ Average } & 우 & 134.62 & 95.29 & 71.01 & 37.93 & 69.40 & 49.97 \\
\hline \multicolumn{2}{|l|}{ Average } & $\sigma^{7} \sigma^{\pi}$ & 145.0 & 104.57 & 78.45 & 41.03 & 75.23 & 53.40 \\
\hline \multicolumn{9}{|c|}{ Gulo "hylaeus" — topotype specimens } \\
\hline Susitna $R$. & 1904 & Q? & 140.3 & 99.4 & 73.9 & 39.0 & 72.2 & 52.2 \\
\hline Susitna R. & 1902 & $0^{x}$ & 150.5 & 113.2 & 82.4 & 40.3 & 79.4 & 52.8 \\
\hline Susitna R. & 1904 & & 148.9 & 110.8 & 77.1 & 41.3 & 78.5 & 55.6 \\
\hline Susitna R. & 1904 & & 143.9 & 100.0 & 74.5 & 39.8 & 76.7 & 55.0 \\
\hline
\end{tabular}

Immature animal; permanent dentition incomplete; weight 8.618 grams.
2 Largest Alaskan specimen examined; weight 17,480 grams; TL $1000 ; \mathrm{T} 210$; HF $192 \mathrm{~mm}$.

presented in another paper (Wright and Rausch, 1953).

A bill providing for a bounty on wolverine in Alaska was introduced in the Territorial Legislature in early 1953. Wolverine are never numerous, and enactment of such a law would cause them to be subjected to greater persecution than is the case under their present status (now may be killed at any time). It also would contribute additional support to the few who hunt animals by aircraft for the bounty, and provide opportunity for the illegal killing of bears and other large animals under the guise of hunting for wolves and wolverine. Wolverine fur is important in the economy of Alaskan Eskimo. There is, 
moreover, no biological knowledge which would support the bounty system insofar as the wolverine is concerned. ${ }^{1}$

Felis lynx canadensis Kerr. Canada lynx.

No information was obtained on the occurrence of the lynx in northeastern Alaska. Hares are on the increase, and it may be expected that lynx will become more numerous in the next few years. It is known that lynx may travel far north of the taiga zone following the decline of the hares. A lynx was obtained from Eskimo who trapped it at the mouth of Publatuk Creek in early 1953. This species was not numerous in the central Brooks Range in $1952-3$.

After consideration of all pertinent material, Ellerman and Morrison-Scott (1951) concluded that there is no justification for splitting the cats into several genera. Moreover, they concluded that Felis lynx is a circumpolar species. Their nomenclature is accepted here. Bobrinskiy et al. (1944) came to the same conclusion earlier. The latter writers also stated that Felis lynx occurs in the "forested regions of North America."

Lepus americanus dalli Merriam. Snowshoe hare.

A large series of snowshoe hares, in winter pelage only, was obtained at Arctic Village. Since Arctic Village is perhaps in the zone of intergradation between $L$. americanus dalli and $L$. americanus macfarlani Merriam, the specimens are assigned to the former with some reservations. No further information was obtained on the status of this hare in arctic Alaska.

Lepus timidus othus Merriam. Arctic hare.

The arctic hare has been rare in northern Alaska for at least five years. The occurrence of this species in arctic Alaska was discussed previously (Rausch, 1951). Hall (1951a), in his synopsis of North American Lagamorpha, pointed out that general comparisons indicate that Lepus otbus is conspecific with the palearctic L. timidus Linnacus. Ellerman and Morrison-Scott (1951) stated that $L$. timidus occurs "Probably in North America." Bobrinskiy et al. (1944) stated that L. timidus occurs in North America. Hall did not make the indicated nomenclature change, but it seems justified on the basis of existing evidence.

An adult male of this species was recently obtained near Wales, on the Seward Peninsula, by E. L. Schiller, of the Arctic Health Research Center. Quay (1951) secured no specimens on the Seward Peninsula, and these hares were known to be rare there during 1947-8.

Marmota marmota broweri Hall and Gilmore. Arctic hoary marmot.

One specimen of this marmot was obtained at Arctic Village, where the species is common. None was observed in the Romanzof Mountains, although it is probable that it occurs there. Twenty-seven of these marmots have been obtained, most of which were collected from the Anaktuvuk Pass region.

${ }^{1}$ As of 1 July 1953 a bounty of $\$ 15.00$ each will be paid on wolverine by the Territory of Alaska. 
M. caligata broweri ( $=M$. marmota broweri) was described by Hall and Gilmore (1934) on the basis of 4 specimens which were received from Charles Brower, of Barrow. Brower had in turn obtained the specimens from Eskimo living at Cape Thompson and Point Lay. To anyone familiar with the topography of western Alaska, it is obvious that suitable marmot habitat cannot exist in the vicinity of these villages, both of which lie on the Arctic Coast, at the edge of the coastal plain. I have attempted to obtain information through talking with old Utukamiut, or Kukmiut, Eskimo who formerly inhabited inland country around the head of the Utukok River. These people, now living in coastal settlements, still hunt far inland, and from their youth have been familiar with the region around the west end of the Brooks Range. The Point Lay people have regularly travelled up the Kukpowruk River to hunt in the mountains, and the country around the head of this river is the nearest possible marmot habitat. Consequently, the probable type locality for $M . m$. broweri is near the head of the Kukpowruk River, at about lat. $69^{\circ} \mathrm{N}$.

The specific status of marmots designated as $M$. caligata (Eschscholtz) has been open to question for several years, as discussed by Ognev (1947). Wehrli (1935) considered the black-capped marmot of Kamchatka to be identical with the nearctic $M$. pruinosa Gmelin (=M. caligata (Eschscholtz)). Bichner (1888, cited by Ognev, 1947) concluded that Arctomys caligata Eschscholtz-: $A$. baibac var. camtschatica Pallas $=A$. camtschaticus Brandt. In regard to this problem, Ognev (1947) stated: "The Kamchatka marmots, unquestionably, are close to the Yakutsk and Transbaykal forms. All of these represent subspecies with respect to their systematic characteristics, and gradually grade one into the other." He stated further: "At the present time it is difficult to divine with sufficient certainty the centre of colonization of the east-Siberian mountain marmots of the group camtscbatica, because of the lack of study of the systematic interrelationships of these marmots with M. caligata Eschscholtz." Also, "It is extremely probable that camtschatica and caligata are related, perhaps even one and the same thing and have common ancestors. ..."

This problem was not considered by Bobrinskiy et al. (1944). Ellerman and Morrison-Scott (1951) listed M. camtschatica as a subspecies of M. marmota Linnaeus, 1758. These writers defined the distribution of M. marmota in Siberia to be ". . . Kamchatka, region of Lake Baikal and Verhoiansk Mountains, in Eastern Siberia, north-eastwards to Anadyr region," and stated that it occurs "Also probably in North America."

Although a large amount of Eurasian material is difficult to obtain in North America, I have assembled an adequate collection of marmot skulls for study. These included series of all North American species of marmots, with the exception of $M$. vancouverensis Swarth, and two of the three Eurasian species (excepting $M$. caudata Jacquemont) from various localities in Europe and Asia. Unfortunately I have not secured any specimens of $M$. marmota camtscbatica, the form probably resembling most closely the North American $M$. caligata. As a result of this work, I have concluded that $M$. caligata is conspecific with $M$. marmota. 

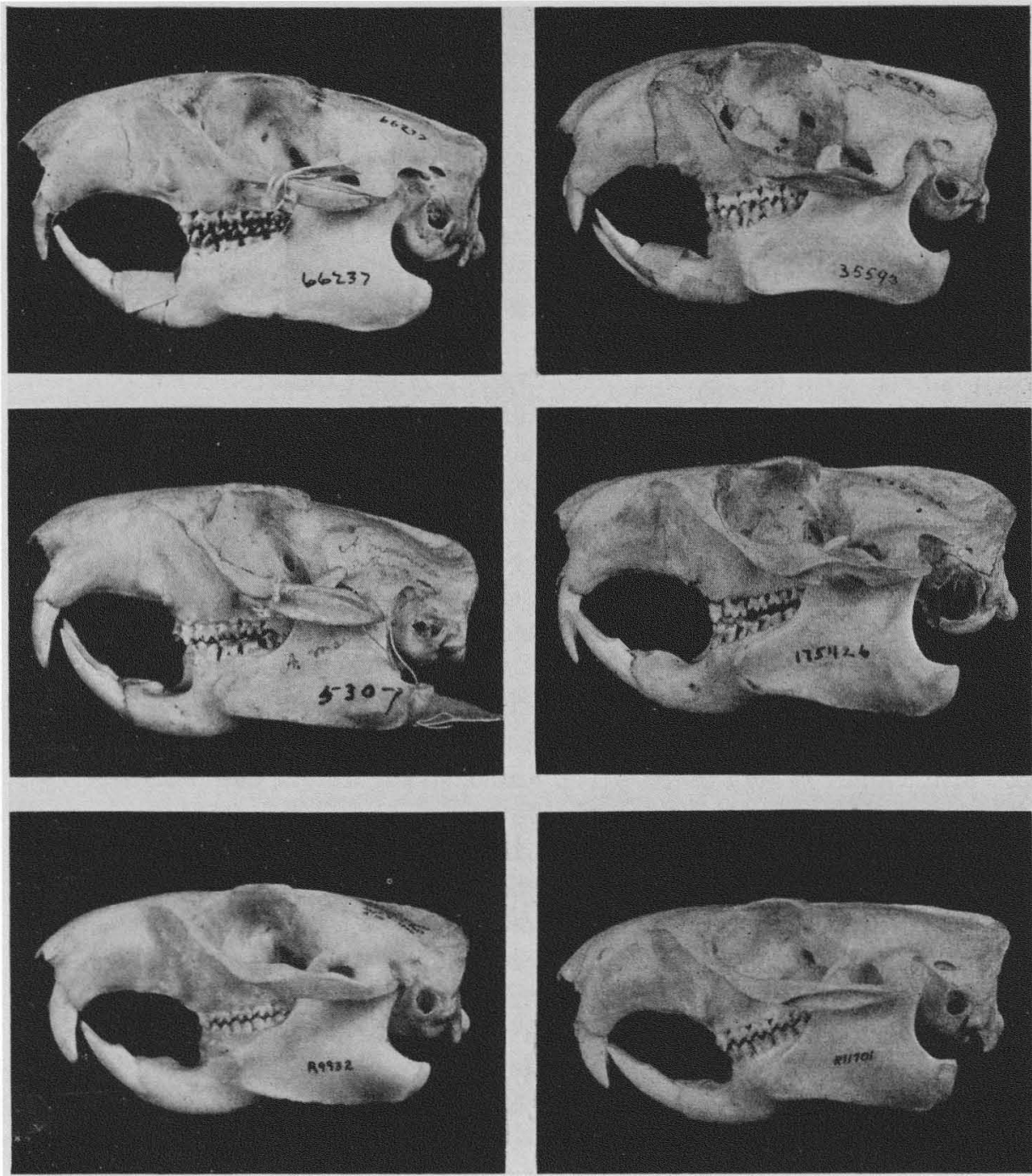

Fig. 7. Skulls of five subspecies of Marmota marmota (reading left to right from top); M. m. marmota L. - 66237, Bavarian Alps; M. m. marmota - 35593, Switzerland; $M$. marmota ssp. - 5307, south Russia; M. m. baibacina Brandt - 175426, Altai; M. m. broweri Hall and Gilmore - R9932, Brooks Range; M. m. caligata Eschscholtz - R11701, southern Alaska.

On the basis of the skulls at hand, it is evident that each form grades into the next, demonstrating a cline which extends from Switzerland and south Germany across Siberia into North America. The European specimens (M. m. marmota Linnaeus) are characterized by a heavy rostrum and strongly arched nasals. Progressing eastward there is a gradual flattening of the dorsal line until the profile is similar to that of North American specimens. This flatness of profile reaches its extreme, in specimens available here, in M. marmota baibacina Brandt, of the Altai. In other cranial details, likewise, closer agree- 
ment with North American forms is seen farther to the east. Considerable variation in cranial details is evident in M. marmota as a whole. Differences may be seen especially in shape of nasals, relative position of fusion-point of temporal ridges, degree of concavity of frontal region, relative size of bullae, shape of parietal bones, degree of concavity and other details of palate, and in mandible shape. Such differences, however, are relatively slight and have only subspecific value. Skulls of representative forms are shown in Fig. 7.

M. marmota broweri differs from the three palearctic subspecies in the following: Nasals narrower, as above. Rostrum lighter, and much less curved than in M. marmota marmota. Zygomata more flaring, and zygomatic processes of the maxillae are relatively much smaller. The angular process of the mandible is relatively smaller. In relation to $M$. marmota baibacina, the squamous temporal bones are narrower dorsally and more deeply indented behind the zygomatic processes. M. marmota broweri resembles the palearctic forms in size of bullae.

M. marmota broweri differs rather strikingly from M. marmota caligata, which has an extensive geographic range in Alaska. The rostrum of $M$. marmota broweri is narrower and less massive. The nasals are narrower and taper backward, the least width being about $2 / 3$ of their length from the anterior ends. The zygomatic processes of the maxillae are very narrow dorsally, where they join the frontal bones and premaxillae; this results in a more abrupt flaring of the zygomata. The zygomatic width is relatively greater in my specimens, although Hall and Gilmore (1934) concluded that the opposite was true. The postorbital processes are more abruptly flaring. The mastoid width is relatively less, and the bullae are larger. The mandible is straighter and the angular process is relatively smaller.

$M$. marmota broweri also differs from $M$. marmota caligata in external appearance, although the colour pattern is essentially typical of the group. It differs from all other races of $M$. marmota that $I$ have seen in the uniform black colouring of the face. This feature alone distinguishes it readily from related forms. The pelage of this marmot is very dense, and the hairs relatively fine-differing in this respect from the related North American forms. The individual hairs are tricoloured: black in the proximal half, then grey distally, with a darker tip. The ground colour is consequently grey, nearest to Pale Smoke Gray. The amount of black is variable, but heaviest dorsally along the midline. There is usually a solid black area covering the third quarter of the body dorsally. This area may be brownish on some specimens, resembling Chaetura Black. The rump area, roughly the last body-fourth, ranges in colour from something darker than Prout's Brown to Warm Buff. The heavilyfurred tail is variegated, a combination of dark brown and Cinnamon-Brown. The belly, throat, legs, and feet are essentially dark grey. The feet are not as lightly coloured in my specimen as Hall and Gilmore's description (1934) implies.

The Brooks Range marmot has a valuable fur. The average price for a good adult raw skin is $\$ 6.00$. The Eskimo find a ready market for the animals they trap. 


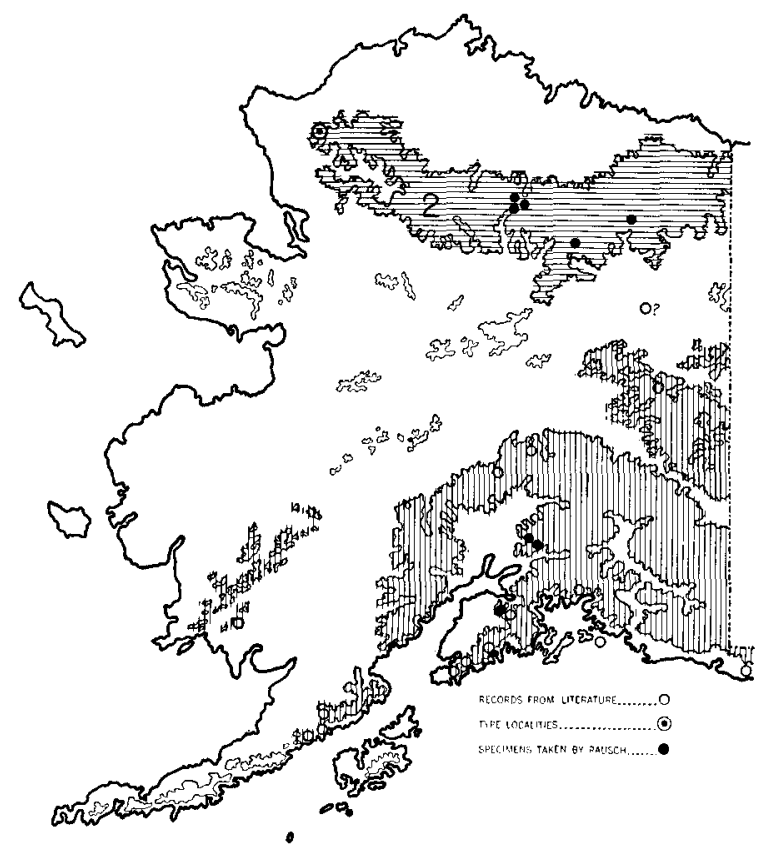

Fig. 8. Distribution of $M$. marmota caligata (1) and $M$. marmota broweri (2) in Alaska. For all distribution maps, mountain ranges are shown, based on the 2,000-foot contour lines.

As a consequence of the broader view taken here of the species, the status of two isolated forms bccomes especially interesting. Both $M$. olympus (Merriam) and $M$. vancouverensis Swarth have been considered well differentiated members of the caligata group. As far as I can determine from the study of adequate material, I see no reason to maintain $M$. olympus as a full species. It is not as atypical as $M$. marmota broweri, for example. The fact of its isolated geographic position does not in itself justify specific rank. It should, in my opinion, be considered a subspecies of $M$. marmota. The situation is probably identical for $M$. vancouverensis. I have not, however, had any material of this form. According to the views set forth here, the names of North American hoary or black-capped marmots should be:
$M$. marmota caligata (Eschscholtz)
$M$. m. cascadensis Howell
M. m. sheldoni Howell
$M . m$. nivaria Howell
M. $m$. vigilis Heller
M. m. okanagana (King)
M. $m$. broweri Hall and Gilmore
M. m. olympus (Merriam)
M. m. oxytona Hollister
$M$. ?m. vancouverensis Swarth

M. m. raceyi Anderson

An up-to-date and more accurate distribution map of marmots in Alaska has been prepared (Fig. 8). This is based on records cited by Howell (1915) and others, and on my material. It is possible that $M . m$. broweri intergrades southwest of the Mackenzie Delta with $M . m$. caligata. Porsild (1945) tentatively assigned to $M$. caligata caligata marmots known to occur west of the Mackenzie Delta and southwest of Aklavik. No specimens were obtained.

If future investigations show the concept of marmot speciation presented herein to be untenable, it would seem to me that $M . m$. broweri would have to be considered a distinct species in view of its morphological differences. 
Citellus undulatus (Pallas). Ground squirrel.

Before any discussion of the Alaskan subspecies of ground squirrel, it is necessary to explain the application here of the name Citellus undulatus (Pallas) instead of $C$. parryii (Richardson).

Ognev (1947) reviewed the literature on the holarctic species of ground squirrel which occurs in Siberia and boreal North America. He quoted Heptner (1939) as being of the opinion that "the American susliks Citellus parryii (with subspecies), as well as C. kodiacensis All. and C. osgoodi Merr., are synonymous with $C$. eversmanni Brandt, and that by the rule of priority all susliks of this group should belong to the species designation Citellus parryii Richardson (1827) as the oldest." Ognev remarked that Argirupolo (Priroda, No. 1 (1939) p. 92) reached the same conclusion. Ognev (1947) pointed out, however, that the description by Pallas (1778) of "Mus citellus variet. undulata" has been overlooked. Consequently, this name antedating that of Richardson, it is necessary to apply the species name C. undulatus Pallas, 1778, "for all susliks of the parryii-eversmanni group in the character of the principal specific designation." Bobrinskiy et al. (1944) used the name C. undulatus for susliks which occur in the "Northern parts of North America and Asia. ..." Ellerman and Morrison-Scott (1951) also accepted this application.

In revising the North American ground squirrels Howell (1938) made little effort to define the relationships existing between the C. parryii group and Siberian forms. He did state, in reference to C. parryii ablusus Osgood, that "This subspecies is closely similar to C. buxtoni (Allen, 1903b, p. 139) [ $=$ C. undulatus leucostictus Brandt, 1844| of eastern Siberia, differing chiefly in less intensely tawny coloration, and more blackish tail; in these characters buxtoni closely resembles C. p. parryii, which, however, is decidedly larger; since buxtoni intergrades in characters with ablusus, it may well be given subspecific status under the name Citellus parryii buxtoni." (p. 100). Allen (1903a) stated: "Citellus buxtoni finds its nearest relative in Citellus barrowensis (Merriam) from Point Barrow, Alaska. . .."

In connection with the animal-borne disease investigations of the Arctic Health Research Center, a total of over 340 ground squirrels has been collected. I have observed all but one Alaskan subspecies in the field (exception: $C$. undulatus nebulicola Osgood). A small series of skulls of Citellus undulatus leucostictus Brandt, 1844, from Mys Emma (Emma Cape), northeastern Siberia, has also been available.

Through the study of this material, considerable new information has been obtained on the geographic distribution of the Alaskan subspecies of C. undulatus. The ranges of these forms have been plotted, using the locality records of Howell (1938) as a basis. Each form is shown on the distribution map (Fig. 9) and is considered separately below.

Citellus undulatus parryii (Richardson). (Fig. 9, No. 1).

Ground squirrels from the Romanzof Mountains and the vicinity of Arctic Village can be referred to C. undulatus parryii. This information changes somewhat the range concept as defined by Howell (1938) for northeastern 


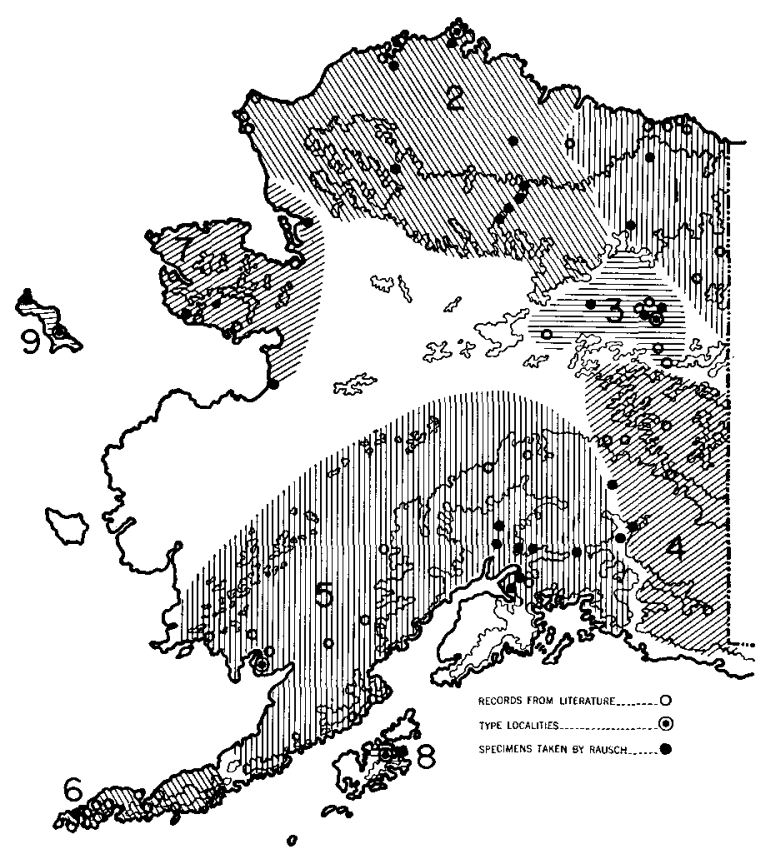

Fig. 9. Distribution of Citellus undulatus in Alaska: (1) C. undulatus parryii; (2) C. undulatus barrowensis; (3) C. undulatus osgoodi; (4) C. undulatus plesius; (5) C. undulatus ablusus; (6) C. undulatus ssp. indet.; (7) C. undulatus ssp. indet.; (8) C. undulatus kodiacensis; (9) C. undulatus lyratus.

Alaska. This form intergrades with C. undulatus barrowensis to the west, and with $C$. undulatus osgoodi to the south, near Arctic Village. The zone of intergradation with C. undulatus barrowensis cannot be accurately determined for lack of information from the region of the Brooks Range drained by the North Fork and Chandalar rivers. This squirrel was very abundant in the Romanzof Mountains during the summer of 1951. Five adult males, collected during July 1951 near Lake Schrader, ranged in weight from 514 to 893 grams (average: 656.6 grams). Four adult females ranged in weight from 638 to 885 grams (average: 718.5 grams).

Citellus undulatus barrowensis (Merriam). (Fig. 9, No. 2).

According to present knowledge, this form occurs throughout the Brooks Range and over the Arctic Slope except where it intergrades with C. undulatus parryii toward the east. The comparison of specimens from the central Brooks Range with topotypes (collected by E. A. Mcllhenny, August 1897) in summer pelage showed good agreement. In winter pelage this squirrel shows much greyness (somewhat lighter than Mouse Gray) over the neck and shoulders. It is of interest that this squirrel has apparently disappeared from Point Barrow as a result of the permanent settlement of many Eskimo there in recent years. It still occurs, however, on the Inaru and Meade rivers, a short distance to the south. I have seen it near the coast about one hundred miles to the west of Barrow, and some sixty miles to the east.

A few observations on this form, not previously reported, have been made. A large adult male, very fat, weighing 723.5 grams, was killed by an Eskimo on 18 November 1951 near Tulugak Lake. The appearance of these squirrels above ground in the fall is intermittent after late September; I have no previous 
record of any emergence later than October 1 (Rausch, 1951). For squirrels emerging in the spring, following hibernation, I have recorded a maximum weight of 977 grams. This animal, an old male, was collected on 6 May 1949, and measured $370 \mathrm{~mm}$. in total length. Other males, some of greater total length, collected from 16 April to 6 May 1949, weighed from 530 to 816.3 grams (average for 7: 646.4 grams). Eight females, collected 20 May to 30 May 1950, ranged in weight from 439 to 616.5 grams (average: 548.2 grams). All specimens collected near Tulugak Lake.

Citellus undulatus osgoodi (Merriam). (Fig. 9, No. 3).

In reference to this squirrel, Howell (1938) stated: "It has a very restricted range along the Yukon River and although closely related to parryii apparently does not intergrade with it." Howell differentiated C. osgoodi on the basis of relatively minor characteristics (colour, size, and "audital bullae averaging slightly smaller and less inflated"). For some time I have considered this form conspecific with other Alaskan ground squirrels, despite its relatively isolated geographic range. As far as I have been able to determine, it inhabits river banks and other higher ground along the Yukon and Porcupine rivers, and is restricted essentially to the Yukon-Porcupine basin.

In June 1951 a rather large collection of mammals was made at Arctic Village. Among the ground squirrels obtained was a specimen which clearly shows intergradation between $C$. osgoodi and C. undulatus parryii. This specimen (orig. No. 10068), an adult male weighing 538.6 grams, was collected on June 19, and retains considerable winter pelage. It is intermediate in colour and tail length. Other specimens collected at the same locality showed more intense colouration than squirrels from the Lake Schrader region, but nevertheless were closer to $C$. undulatus parryii. This observation supports the conclusion that this squirrel should have only subspecific status.

With the longer tail, the total length of C. undulatus osgoodi is greater than that of any other Alaskan form of $C$. undulatus. However, the animal itself is not unusually large. The heaviest specimen I have examined, a male, collected August 1 on the Porcupine River, weighed 700 grams. Howell (1938) gave a maximum weight for males as $2 \frac{1}{4} \mathrm{lbs}$.

Citellus undulatus plesius (Osgood). (Fig. 9, No. 4).

I have collected this squirrel in the Yukon Territory, and near the western limits of its range in Alaska. The latter may show some intergradation with ablusus. The Alaskan distribution as given here is essentially after Howell (1938), with additions from the recent literature (Baker, 1951; Strecker et al., 1952). Slight modifications are made on the basis of topographic features, also. The zone of intergradation with $C$. undulatus ablusus Osgood may be rather extensive.

Citellus undulatus ablusus Osgood. (Fig. 9, No. 5).

The collection of a large series of ground squirrels in the Talkeetna Mountains and farther east has permitted some extension of the known range of this form. Although topotype specimens have not been compared, the 
Talkeetna Mountain material compares well with examples from Unalaska and localities near the base of the Alaska Peninsula.

Howell (1938) referred squirrels from the Seward Peninsula to this form. According to his distribution records and my own observations, however, the Seward Peninsula population is separated from the main geographic range of C. undulatus ablusus by a wide region in the lower Yukon valley, within which apparently no ground squirrels occur (see Fig. 9, No. 7). Specimens have been obtained from Unalakleet, Nome, and Kotzebue in connection with the present work. It is true that these specimens agree in colour with $C$. undulatus ablusus. Tail length, however, agrees with C. undulatus barrowensis, with which intergradation probably takes place to the north. It appears that further study is needed before the Seward Peninsula form can be accurately designated. Quay (1951) referred his specimens to ablusus, probably on the basis of Howell's work.

Specimens from the lower Alaska Peninsula (Fig. 9, No. 6) cannot be assigned to ablusus, although Howell (1938) did so. The small series which I have at hand from the lower Peninsula is much paler in colour throughout. Osgood (1904) stated: "The Cold Bay specimens are not typical ablusus, but at present can be referred to no other form." This form appears to represent a distinct race; it will be described elsewhere.

Citellus undulatus kodiacensis (Allen). (Fig. 9, No. 8).

Howell (1938) considered the Kodiak Island squirrel to be specifically distinct from the mainland form. I do not agree that such a view is tenable, since structural differences are relatively slight. Early workers treated this form as a subspecies of C. parryii. Heptner (1939; cited by Ognev, 1947) concluded that kodiacensis and osgoodi were subspecies of $C$. parryii. It is treated here as a subspecies of C. undulatus.

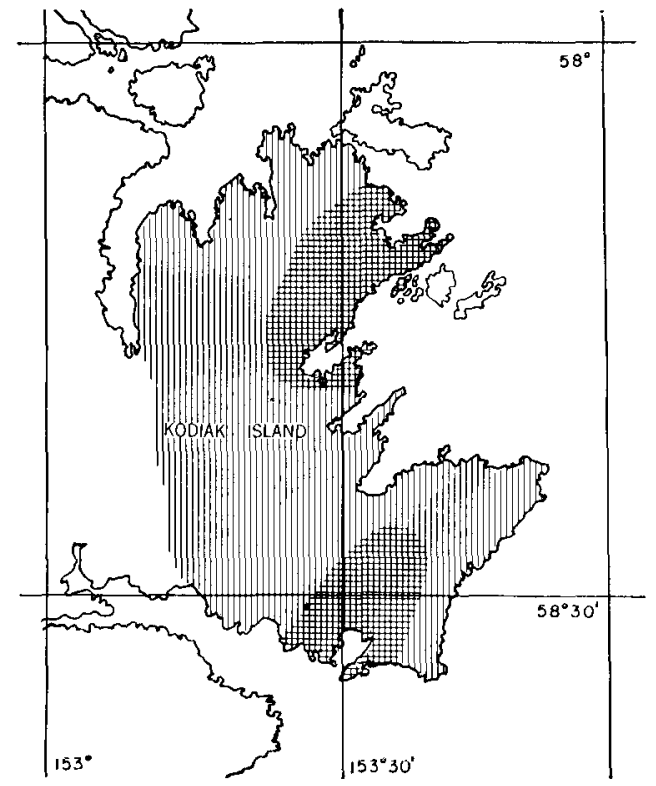

Fig. 10. Kodiak and neighbouring islands showing distribution of C. undulatus kodiacensis. Heavily shaded areas indicate known occurrence; lighter shading indicates probable occurrence. 
It was stated by Osgood (1903) that this ground squirrel was thought to have been introduced on Kodiak from another island. Howell (1938), however, stated that the character of the Kodiak squirrel was such that it appeared to have been on the island for a long time. On the other hand, Hrdlicka (1944) did not find any ground squirrel bones during his excavations on Kodiak Island. It would seem that such would have been noted if squirrels had been present in earlier years. It is apparent that the range of $C$. undulatus kodiacensis is curiously restricted. I have not been able to make thorough observations on the island, but am certain that much suitable habitat is not occupied. Russell R. Hoffman, Refuge Manager, U.S. Fish and Wildlife Service, Kodiak, has kindly prepared a map of ground squirrel distribution (Fig. 10) insofar as he could determine from his own experience and from that of others familiar with the island. It is entirely possible that these squirrels were introduced on Kodiak. Further study is required to determine their origin, should this be true. ${ }^{1}$

Citellus undulatus lyratus Hall and Gilmore. (Fig. 9, No. 9).

The ground squirrel of St. Lawrence Island, of which more than 80 specimens have been collected in connection with this work, closely resembles C. undulatus leucostictus Brandt of northeastern Siberia. This fact was pointed out by Howell (1938). Study of both forms confirms this conclusion. This squirrel has been considered in more detail in another publication (Rausch, $1953)$.

There is need for additional Citellus undulatus material from Alaska if some points in geographic distribution of the various forms are to be clarified. This would be particularly desirable in regions rarely visited. It appears that the construction of highways may considerably influence the abundance and distribution of ground squirrels in Alaska. In this manner suitable continuous habitat is provided, along which the squirrels move.

Citellus undulatus has been widely studied in Siberia, and is receiving considerable attention in North America as an arctic species suitable for laboratory investigation. It is consequently of importance that workers concerncd be acquainted with the circumpolar distribution of this species in order to take advantage of existing literaturc. Too often important knowledge is obscured by nomenclatural complexities and thus is lost to the highly specialized investigator.

A thorough discussion of the characteristics of palearctic forms of $C$. undulatus has been published by Ognev (1947). Cranial and external differences have been discussed in great detail, including also seasonal pelages of various subspecies. Ognev also reviewed the literature on the ecology and bionomics of the species.

1Field observations on Kodiak Island were continued for a period of one month, during May-June 1953. During this time, in late June, a single ground squirrel, apparently killed by a bear, was observed on a mountain at Karluk Lake by Alf Madsen, a professional guide. Mr. Madsen has had years of guiding experience on the island, and was much surprised to observe this squirrel so far from the known range of the species. The significance of this finding is not clear at present. 
Tamiasciurus hudsonicus preblei Howell. Mackenzie red squirrel.

The tree squirrel of the Brooks Range, from Anaktuvuk Pass to the east, at least can clearly be referred to $T$. budsonicus preblei. Comparisons have been made with topotype material (Fort Simpson, District of Mackenzie) and with material from other localities farther east. In addition to some 70 specimens from the central Brooks Range (see Rausch, 1951), about 50 additional animals have been collected from the vicinity of Arctic Village, Fort Yukon, and Beaver. An unusual occurrence of this species was recorded near Anaktuvuk Pass, far to the north of the taiga zone. Here, an adult female squirrel weighing 228.7 grams was killed on 7 August 1952, in the willows (S. alaxensis) by an Fskimo. This animal has been deposited, preserved entire, in the U.S. National Museum.

The occurrence of pale-coloured squirrels in the central Brooks Range was mentioned earlier (Rausch, 1951), and similar specimens were collected near Arctic Village. In general, they comprise a rather large proportion of the population. The most light-coloured specimen so far obtained was collected 6 December 1950, in the Savioyok valley east of Anaktuvuk Pass. It is briefly described:

Top of head and dorsum, except along midline, slightly darker than Ochraceous Buff. Along midline of last $2 / 3$ of dorsum colour is near Xanthine Orange. Tail cssentially Ochraceous Buff with lateral margins approaching typical dark colour; amount of dark colour greatly reduced, however. Ochraceous Buff of back becomes more buffy on the sides. Lateral stripe well defined, but grey rather than black. Face buffy; eye ring and nose buffy-white; cheeks greyish. Dorsal part of legs and feet approaching normal colour, but paler. Belly pure white.

Lemmus sibiricus trimucronatus Merriam. Brown lemming.

The brown lemming was abundant in the Romanzof Mountains during the summer of 1951. It was numerous on Barter Island during the same time, but was rare farther to the west. This seems to indicate that at least two distinct populations exist on the Arctic Slope. Farther west, in the Point Barrow region, the lemmings attained a high density in 1949 (see Rausch, 1950a), and then were scarce until the summer of 1952 , when a moderately high density was again attained. Whether these animals will still be abundant during the summer of 1953 is difficult to judge. During December 1952, on a dog team trip of over two hundred miles along the Arctic Coast, I saw only one lemming on the surface of the snow. It was not possible to make adequate observations on conditions beneath the snow cover.

The Indians at Arctic Village could not provide any information on this species, and none was collected.

Ognev (1947) established that the Alaskan brown lemming is conspecific with the Obskiy lemming, known until recently as Lemmus obensis Brants, 1782. True (1885) had also referred the Alaskan form to L. obensis. Lemmus obensis chrysogaster was described by J. A. Allen (1903a) from the environs of Gizhiga, near the coast of the Sca of Okhotsk. Allen pointed out that it was similar to the Alaskan form; comparisons with Point Barrow specimens disclosed "no distinctive cranial differences." G. M. Allen (1914) described the 
"little Kolyma lemming," designated as L. paulus, from near the mouth of the Kolyma river, and also reported L. obensis cbrysogaster from Mys Bol'shoy Baranov, on the northeastern coast of Siberia. Ognev (1947) concluded that L. paulus is not distinct. Consequently, a single species of Lemmus occurs in Alaska and Siberia, with a second species, Lemmus lemmus Linnaeus, ranging from Norway, Sweden, and Finland, to the Kol'ski Poluostrov (Kola Peninsula), northwestern Russia.

Ellerman (1949) pointed out that the prior name of the Siberian lemming is Mus lermmus sibiricus Kerr, 1792. This animal, as cited from Kerr by Ellerman, was described as "of a smaller size, and a more uniform tawny color" than Mus lemmus (=Lemmus lemmus). The type locality of the former was given as the "Northern parts of the Uralian chain of mountains, and on the River Oby." Consequently, the name L. sibiricus is used here to designate the brown lemming of North America.

Lemmus nigripes (True) occurring on St. George Island, Pribilof group, has been considered specifically distinct from the brown lemming of Alaska. It was distinguished on the basis of slight colour differences, and by the fact that the auditory bullae are relatively small. Davis (1944) pointed out that this lemming is closely related to the mainland form, as well as to that of Nunivak Island. Davis concluded that "it seems best to treat nigripes as a full species." On the basis of comparisons, and in consequence of a broader view taken of the group, it does not seem justified to maintain $L$. nigripes as a full species. It is treated here as a subspecies of $L$. sibiricus.

follows:

North American forms of the brown lemming may be designated as

Lemmus sibiricus trimucronatus (Rich- Lemmms sibiricus alascensis Merriam ardson) Lemmis sibiricus barroldi $\mathrm{S}$ warth

Lemmus sibiricus belvolus (Richardson) Lemmus sibiricus nigripes (True)

A breeding colony of brown lemmings has been established in the laboratory at the Arctic Health Research Center. Kept under continual illumination for some months, a pair of lemmings began reproduction in late December 1952 , and to date five litters, totalling 23 young, have been produced. These animals have become thoroughly adapted to confinement, and it is anticipated that there will be no further difficulty in maintaining them under laboratory conditions.

Dicrostonyx torquatus rubricatus (Richardson). Alaska varying lemming. Varying lemmings were numerous in the Romanzof Mountains during the summer of 1951, and a small series was collected. No specimens were obtained at Arctic Village, but the species occurs there if one may judge from descriptions by the Indians. The people recognize a white "mouse" which in some years becomes abundant.

Ognev (1947) considered the North American collared lemming probably conspecific with the palearctic form. Ellerman and Morrison-Scott (1951) concluded that $D$. torquatus probably occurs in North America. In conparing skulls of $D$. torquatus with those of North American forms, Hinton (1926) stated that the former had "Upper incisors moderately heavy and much 
more strongly curved than in $D$. gronlandicus ... those of D. rubricatus being apparently intermediate." In discussing D. rubricatus, Hinton stated further that " $D$. rubricatus is undoubtedly very closely related to the Old World D. torquatus, and until more material representing the latter is available, the status of D. rubricatus will remain doubtful."

The few specimens of $D$. torquatus which I have examined from northeast Siberia differ externally from Arctic Slope specimens only in greater intensity of colour. Colour is highly variable, both in Eurasia and in North America. Cranially there appears to be no differences of specific value, although there has not been adequate palearctic material available to establish average measurements. In view of the above-mentioned opinions, coupled with my own observations, I consider it appropriate to regard D. groenlandicus conspecific with D. torquatus. The names for North American races would consequently become:

Dicrostonyx torquatus rubricatus (Mer- I). torquatus kilangmiutak Anderson and riam)

D. torquatus groenlandicus (Traill) D. torquatus richardsoni (Merriam)

D. torquatus exsul Allen

I have had no specimens of $D$. budsonius (Pallas) available for comparative study, nor likewise any specimens of $D$. unalascensis Merriam. It is improbable that the latter has full specific standing. It was described on the basis of skulls from owl pellets, and apparently no comparisons with really adequate material have been made. G. M. Allen (1919) in his review of the American collared lemmings, after comparative study considered unalascensis a subspecies of rubricatus, since Merriam had previously compared it only with $D$. budsonius at the time of its description. The external characteristics of this form were described by Gilmore (1933). D. torquatus exsul is considered in detail in another paper (Rausch, 1953). The Canadian varying lemmings were reviewed by Anderson and Rand (1945b), but these writers did not make any comparisons with palearctic material.

Clethrionomys rutilus dawsoni (Merriam). Red-backed vole.

Two specimens of this vole were collected at Lake Schrader, and a large series was trapped at Arctic Village. A single specimen trapped near the head of the Utukok River apparently constitutes the northwesternmost record of this species in Alaska. Farther west, specimens were collected at Nome and Kotzebue. A total of 240 specimens has been examined for helminth parasites (Rausch, 1952).

On the basis of present knowledge, a single form occurs over most of Alaska and adjacent Canada. Variation in pelage colour is considerable, so this character has little value in the differentiation of local races. I have also noted rather remarkable variation in size. However, Hanson (1952) has recently described a form from the Barren Grounds of the Perry River area, District of Mackenzie. Banfield (1951a) remarked that the tundra red-backed voles which he collected in northwestern Canada might be distinct. It is probable that the form to which he referred is the same as described by Hanson as C. rutilus wasbburni. 
C. rutilus has a wide holarctic distribution. The status of the North American form was determined by Rausch (1950b). The Eurasian forms of C. rutilus have been studied by Ognev (1950). On the basis of more than 2,000 specimens, he was able to define the characteristics of palearctic subspecies. Ognev stated: "The colour of the fur is subject to great variations that depend on age, the season of generation of the animal, as well as on the geographical region from which the specimen in question came." He also reviewed the Russian literature in detail, summarizing considerable data on breeding, food habits, and habitat.

The red-backed vole is easily maintained in the laboratory. Breeding occurs regularly under favourable conditions.

Microtus oeconomus Pallas. Tundra vole.

A few specimens of $M$. oeconomus were collected near Lake Schrader, and a large series was obtained from the vicinity of Arctic Village. This vole occurs over all of Alaska, as well as in northwestern Canada as far east as Coronation Gulf.

Zimmerman (1942) demonstrated that $M$. oeconomus has holarctic distribution. Zimmerman's conclusions were confirmed by Rausch (1950b). In Siberia $M$. oeconomus tshuktshorum Miller occurs nearest Alaska, and $M$. oeconomus operarius Nelson is the North American form most closely related to it, according to Ognev (1950).

Rausch (1950b) listed ten North American subspecies of $M$. oeconomus. Setzer (1952) described M. oeconomus gilmorei, and Hall and Cockrum (1952) concluded that $M$. amakensis Murie is also only subspecifically distinct. Osgood (1909) described M. endoecus ( $=$ M. oeconomus endoecus) from the mouth of Charlie Creek, on the Yukon River. This subspecies was differentiated from $M$. oeconomus operarius and $M$. oeconomus macfarlani on the basis of certain cranial differences. Anderson (1937), on the opinion of R. C. Gilmore, concluded that $M$. oeconomus endoecus cannot be distinguished from $M$. oeconomus macfarlani, and consequently listed it as a synonym of the latter. Setzer (1952) stated that the two forms might be separable, on the basis of cranial differences. From the study of a large volume of material, it is concluded that Setzer's supposition is valid and consequently M. oeconomus endoecus is listed below as a distinct form.

A distribution map has been prepared for $M$. oeconomus in Alaska, excluding certain island forms whose range is well defined. The mainland races are discussed separately.

Microtus oeconomus endoecus Osgood. (Fig. 11, No. 1).

This form occurs over most of eastern and central Alaska, according to material at hand. Large series have been obtained from Arctic Village, Fort Yukon, and Beaver, as well as from other localities farther to the south and west. Comparisons of Lake Schrader and Arctic Village specimens with $M$. oeconomus macfarlani from Bathurst Inlet, Northwest Territories, indicate that the former are much closer to endoecus than to macfarlani, although there is some evidence of intergradation. I referred specimens from the 


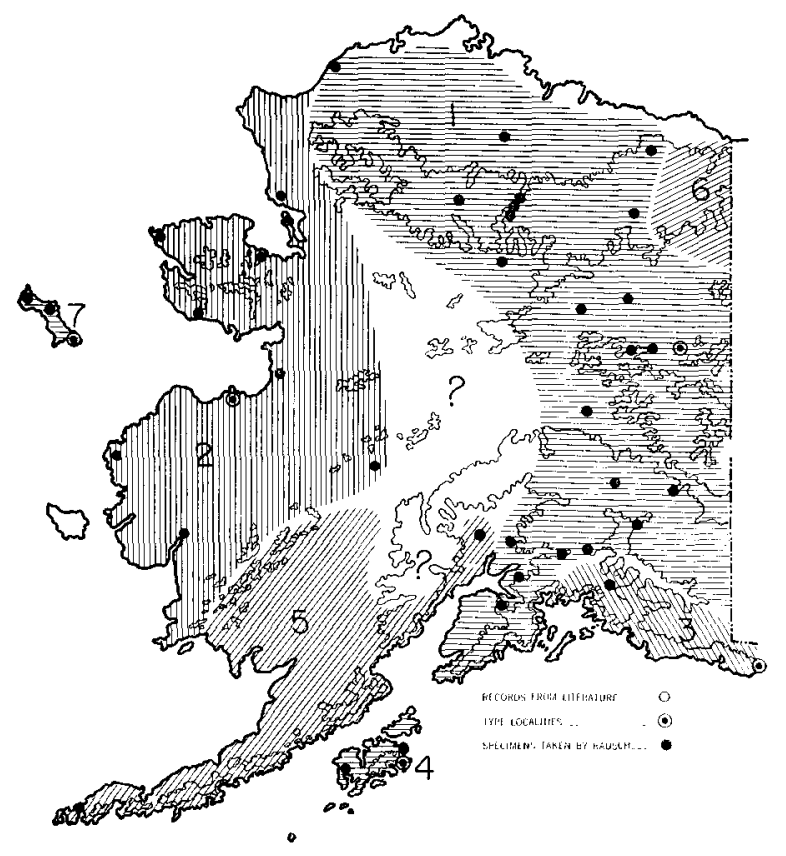

Fig. 11. Distribution of Microtus oeconomus in Alaska: (1) M. oeconomus endoecus; (2) M. oeconomus operarius; (3) M. oeconomus yakutatensis; (4) $M$. oeconomus kadiacensis; (5) M. oeconomus ssp. resembling kadiacensis; (6) M. oeconothus macfarlani; (7) M. oeconomus innuitus.

Anaktuvuk Pass region and Uniat to macfarlani (=-endoecus) but Setzer (1952) (who also studied material collected here, deposited earlier in the U.S. Nat. Mus. collection) concluded that these specimens showed intergradation between $M$. oeconomus macfarlani (=endoecus) and $M$. oeconomus gilmorei Setzer. In Alaska, M. oeconomus macfarlani has a very restricted range (Fig. 11, No. 6).

From the material collected over northern Alaska, additional observations may be made on the status and distribution of certain forms. I first obtained a specimen of $M$. oeconomus from Point Lay, Alaska (topotype of $M$. oeconomus gilmorei) in the spring of 1949, and subsequently secured many more. A total of 187 specimens from this locality was examined for helminth parasites, and about 200 more were utilized in other ways. A good series of adult specimens has been assembled for study. Most of these animals were collected in late summer and therefore are comparable with most other Alaskan material in the collection here. large series of voles were also obtained at Noatak, Deering, Unalakleet, and McGrath, and smaller series from Nome, Kotzebue, Wales, and Bethel. All of these specimens, in my opinion, should be referred to M. oeconomus operarius (Fig. 11, No. 2). The Point Lay specimens are relatively dark, and probably demonstrate intergradation between M. oeconomus endoecus and M. oeconomus operarius. I do not, on the basis of available material, consider $M$. oeconomus gilmorei distinguishable.

Microtus oeconomus ?kadiacensis Merriam. (Fig. 11, No. 4).

A series of voles collected near Skwentna, on the Skwentna River northwest of the head of Cook Inlet (Fig. 11, No. 5), closely resembles $M$. oecono- 
mus kadiacensis. The Skwentna specimens are closest to Raw Umber above, with the sides near Saccardo's Umber, and Pale Drab-Gray underparts. Voles from Kodiak are more drab, with a tendency toward brownish. Osgood (1904) collected some voles which he referred to $M$. oeconomus kadiacensis along the coast of Bristol Bay and around the base of the Alaska Peninsula. Allen (1902) provisionally referred a vole from the tip of the Kenai Peninsula to this form. I have found those from near the base of this Peninsula to be referable to $M$. oeconomus endoecus, however. As far as I have been able to determine on the basis of limited material, all the Alaska Peninsula voles are of the same type - similar to $M$. oeconomus kadiacensis. It is possible that $M$. oeconomus kadiacensis is restricted to Kodiak and nearby islands. If so, voles from the Alaska Peninsula will have to be designated as a distinct subspecies. In any event, further study is needed.

Microtus oeconomus yakutatensis Merriam. (Fig. 11, No. 3).

This form has a restricted range in southern and southeastern Alaska. Some additional work is needed to define its range more accurately.

Previous attempts with three different forms of $M$. oeconomus to establish laboratory colonies, have been unsuccessful, but at the time of writing, however, a pair of voles, $M$. oeconomus endoecus, captured as subadults at Beaver, on the Yukon River, has produced a litter of $t$. It is hoped that a breeding colony will be developed from this beginning.

Gilmore (1946) stated that M. kamtschaticus ( $=$ M. oeconomus) has not been observed to show distinct fluctuations in population density as contrasted with M. miurus. Quay (1951) commented briefly on this point. However, certain published records and my own observations do not support Gilmore's assumption. Allen (1902), writing of M. oeconomus popofensis Merrian, quoted J. D. Figgins that "Popof Island was literally overrun with these mice" during the fall of 1901. Bailey and Hendee (1926) mentioned that $M$. oeconomus operarius was reported as being "very common" at Cape Prince of Wales during the spring of 1922. Osgood (1904) found M. oeconomus kadiacensis "exceedingly abundant" at Nushagak. M. oeconomus inmuitus Merriam (Fig. 11, No. 7) was abundant at the west end of St. Iawrence Island during 1950 and 1951. I found little evidence of this vole in the early spring of 1950, while there was still deep snow cover. However, E. L. Schiller, who continued observations the same year, found them "very abundant" after the snow was gone. We obtained more than 500 of these voles without difficulty for parasite studies. $M$. oeconomus was abundant at Point Lay in the spring and summer of 1951, and Utukamiut Fskimo have told me of having observed high densities. During the fall of 1952, M. oeconomus endoecus was at a high level of population density in the Yukon-Porcupine basin. The voles were especially abundant in the beds of old overflow lakes, and in many places the ground was nearly covered with soil loosened by their excavations. Consequently, it appears that $M$. oeconomus populations do fluctuate in density. Although Ognev (1950) gave detailed information on the ecology of $\dot{M}$. oeconomus, nothing specific was included on population densities. 
Microtus miurus Osgood. Narrow-skulled or gregarious vole.

The microtine subgenus Stenocranius Kastschenko is represented in North America by a single species, M. miurus Osgood. Five subspecies are recognized, of which three occur in Alaska. All inhabit arctic or alpine habitats. I have collected this species frequently, and considerable information on its Alaskan distribution has been obtained (Fig. 12). The Alaskan subspecies are discussed separately.

Microtus m. miturus Osgood. (Fig. 12, No. 1).

Reported previously only from the Kenai Peninsula (Osgood, 1901; Allen, 1902), I have collected this vole in the Talkeetna Mountains, about eighty miles north of Anchorage, as well as from the head of Palmer Creek, near the type locality. Colonies have been scattered and relatively small during the time of this work, as is characteristic when the population density is at a low level.

Since the habitat of $M . m$. miurus has not been described in detail, a few remarks are included here. The Kenai Peninsula colony was found near the head of a talus-covered valley, at an altitude of about 3,000 feet. At the highest point, the burrows had been excavated among the rocks, as well as in the open. The burrows were numerous, and runways extended down a steep slope for a distance of at least 200 metres. The plant association consisted essentially of Luetkea pectinata (Pursh) Kuntze, and Cassiope Stelleriana (Pall.), with Phyllodoce ?aleutica (Spreng.) appearing a few hundred feet below the highest level. A few other species of plants were interspersedmainly Carex spp. and Lycopodium sp. The soil was moist, since flowing

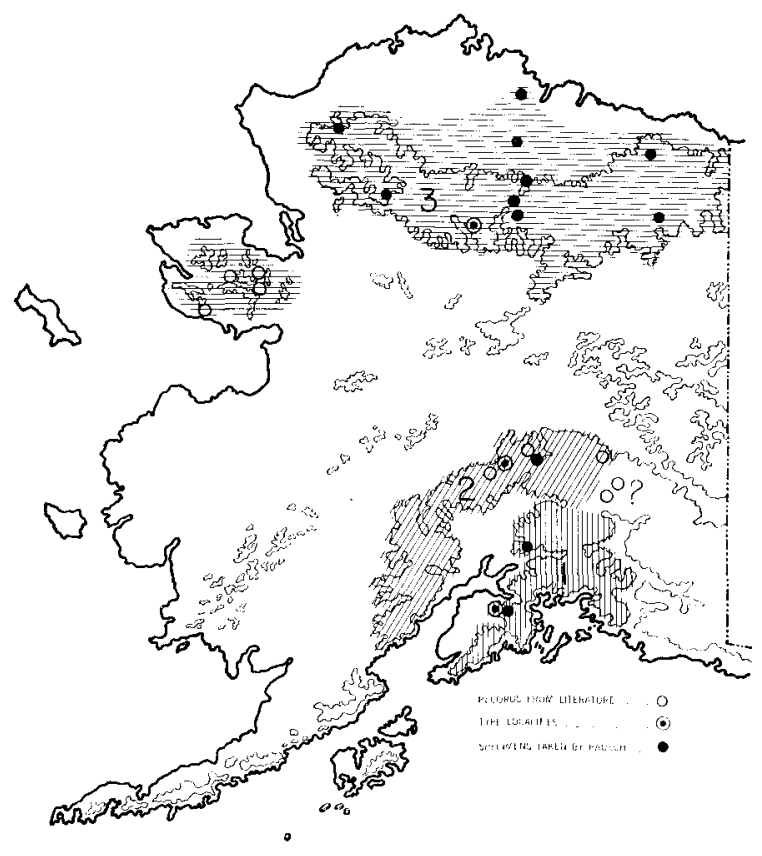

Fig. 12. Distribution of Microtus miturus in Alaska: (1) $M$ miturus miurus; (2) $M$. miurus oreas; (3) $M$. miurus muriei. 


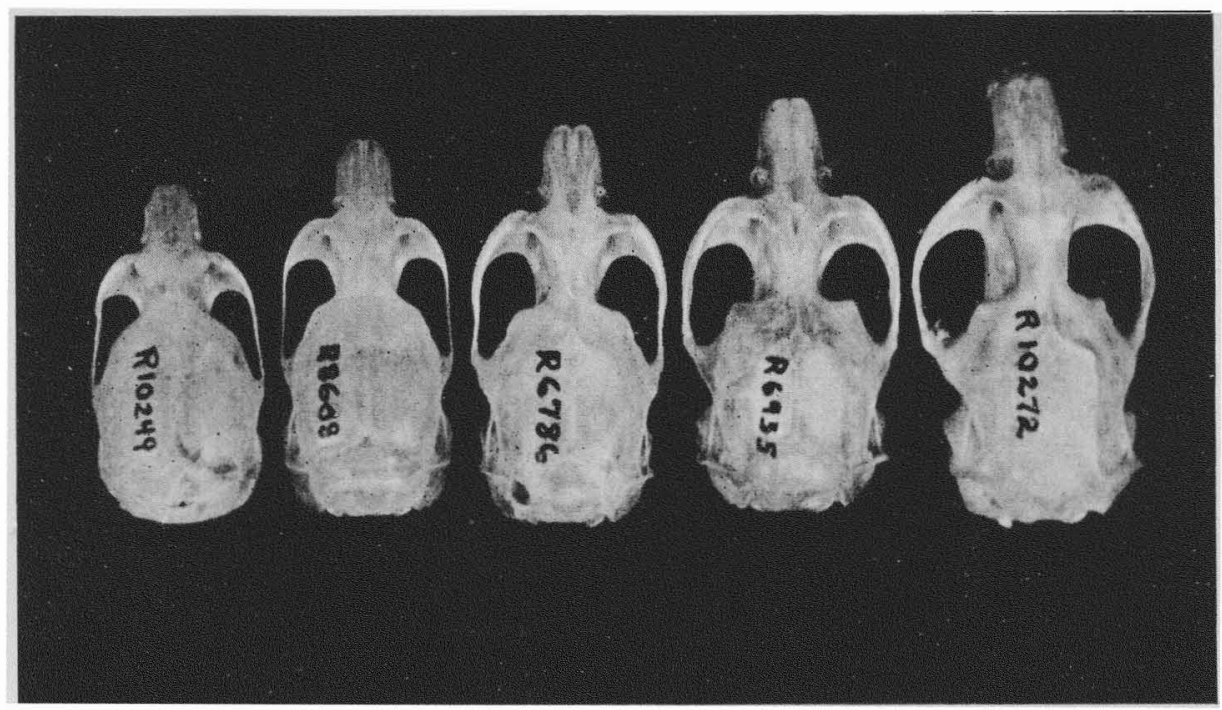

Fig. 13. Skulls of $M$. miurus muriei, wild-trapped specimens, showing cranial changes associated with growth. All males but the smallest. Second skull from left similar in stage of development to that of specimen described by Nelson as M. muriei.

springs were numerous in the immediate vicinity. The burrows were inconspicuous among the rocks, and it was only in the open that excavated soil was noted at the burrow entrances. These latter burrows apparently were storage chambers, since there was a heavy growth of Carex sp. nearby. The rhizomes of Carex are commonly stored by $M$. miurus. Dwarf willows were rare, and there was no evidence that $M$. miurus prepared "hay-piles" of willow or other plants for winter use.

The colony observed in the Talkeetna Mountains was found on the slope of a low mountain at an altitude of about 3,000 feet. Vegetation was dense, and the main species of plants were Luetkea pectinata, Cassiope Stelleriana, Empetrum nigrum L., Salix reticulata L., and Salix sp. Other plants, including Vaccinium uliginosum L., Sanguisorba sp., Rubus sp., and Carex spp. were interspersed. Larger species of Salix were absent. Here again there was no evidence of "hay-drying", although observations were made over a period of two summers.

It is probable that $M . m$. miurus occurs throughout the Talkeetna and Chugach Mountains. Much additional work is needed to determine its geographic distribution in southern Alaska.

Microtus miurus oreas Osgood. (Fig. 12, No. 2).

This form appears to be restricted in its distribution to the Alaska Range, where it was first observed in the Mount McKinley region. Here it occurs in the zone of mixed taiga-tundra as well as in the arctic-alpine zone. I have had but a few specimens of this vole, obtained through the courtesy of Dr. Adolph Murie. I have, however, had the opportunity of observing the habitat. This vole was described as an alpine species by Osgood (1907), who received 


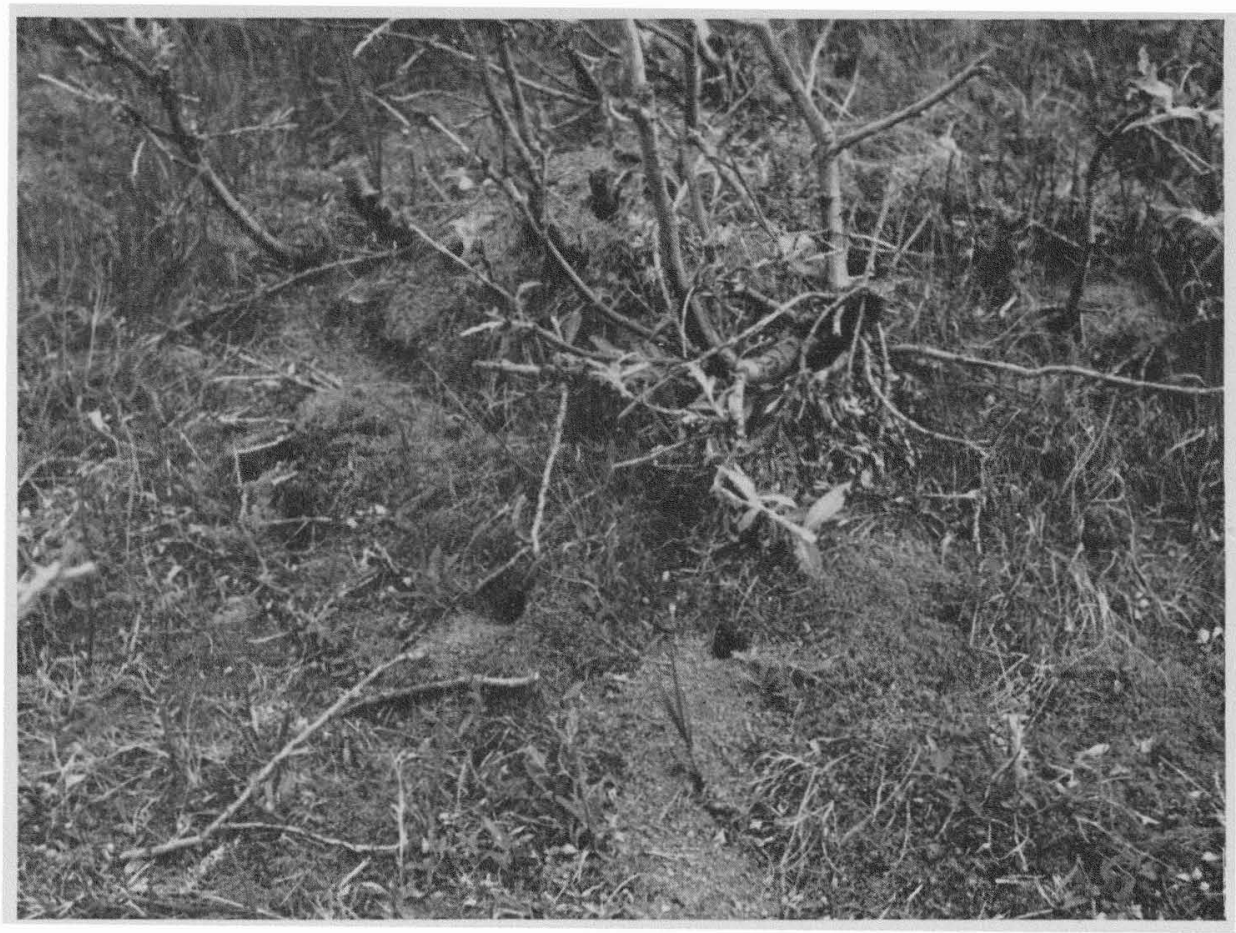

Fig. 14. Typical burrows of M. mizurus muriei in Salex alaxensis-Hylocomium splendens association, Lake Schrader.

the prepared specimens from the collector. Detailed observations were given by Murie (1948), who first described its "hay-storing" habit. Recently this vole has been reported from Gakona Glacier, farther to the east (Strecker et al., 1952).

Microtus miurus muriei Nelson. (Fig. 12, No. 3).

A single form of $M$. miurus occurs in the Brooks Range. Specimens from the Anaktuvuk Pass region served as the basis for the description of M. miurus paneaki (Rausch, 1950b). Nelson (1931) described M. muriei on the basis of a single immature specimen taken on the Kutuk River (see Fig. 13). Hall and Cockrum (1952) reviowed all the nearctic members of the Stenocranius group and concluded that M. miurus paneaki and M. muriei are conspecific. Since Nelson's name has priority, $M$. miurus paneaki consequently became $M$. miurus muriei, as pointed out by Hall and Cockrum. Figure 13 shows cranial growth changes in $M$. miurus muriei.

Three hundred specimens of $M$. miurus muriei, the majority from the central Brooks Range, have been examined for helminth parasites (Rausch, 1952). Series of specimens were collected in the Romanzof Mountains, and at Arctic Village. Three of these voles were trapped at the head of the Utukok River in the autumn of 1952, and unmistakable evidence of their occurrence was observed at the junction of the Cutler and Noatak rivers, 


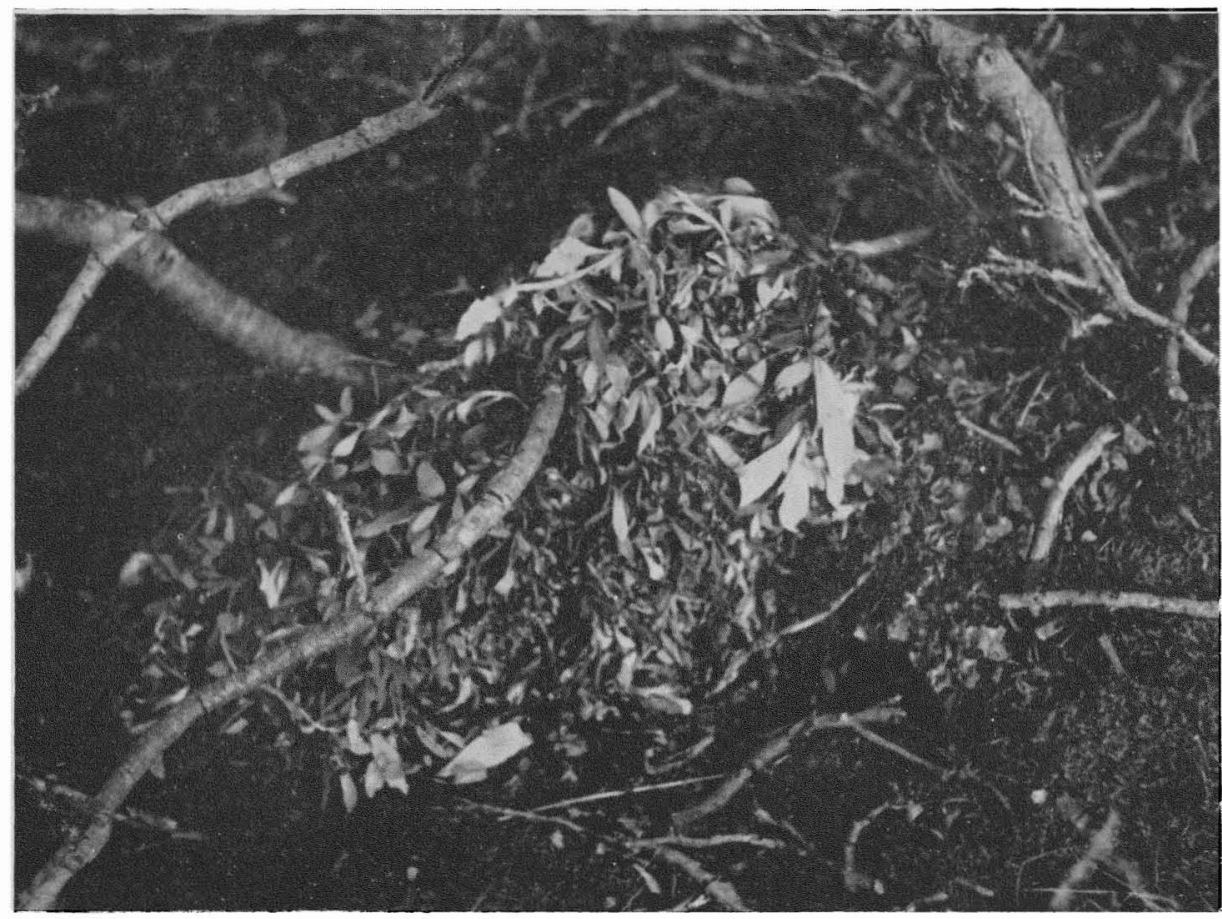

Fig. 15. "Hay pile" of $M$. miurus muriei near Lake Schrader, Romanzof Mountains. Composed exclusively of Salix spp.

although none was collected. Adam Leavitt, a Barrow Eskimo who lived for several years along the Arctic Coast east of Point Barrow, described characteristic "hay piles" which he observed along Fish Creek, just southeast of Teshekpuk Lake. These voles had previously been collected as far north as Umiat, on the Colville River (Rausch, 1950b).

The voles taken in the Romanzof Mountains were trapped mainly along the shores of Lake Schrader, where their burrows were located but a few feet above water-level. A large colony was found in a moist area along the north shore of the lake. The vegetation here consisted essentially of Cassiope tetragona (L.) and Iryas octopetala L., with several other species interspersed, namely, Anemone parviflora Michx., Geum Rossii (R. Br.) Ser., Ranunculus sulphureus Soland, and Dodecatheon frigidum C. and S. Along the lake margins Petasites frigidus L. was abundant, and Therofon Richardsonii (Hook.) was found in moist situations. Lichens and mosses were abundant.

$M$. miurus occurred abundantly in the willow-moss ( $S$. alaxensisHylocomium splendens (Hedw.)) associations on the alluvial flats and along the stream at the west end of Lake Schrader. Twenty-four animals were taken from thirty traps over a single night. Willows (S. alaxensis) of rather large size occurred on the moss-covered hummocks in which the vole burrows were located (Fig. 14). The voles were present under similar conditions along Lake Peters. In no case was there evidence that they occurred at altitudes 
appreciably higher than the lakes themselves, in contrast to what was observed farther to the west. It was here that the "hay-drying" habit was much in evidence. Large piles of willow twigs, some containing more than two thousand, were placed among and upon the trunks of S. alaxensis (Fig. 15). Four species of willow-twigs were represented: namely, S. alaxensis, S. reticulata, S. barrattiana Hook., var. angustifolia Anders., and S. walpolei (Cov. and Ball.) Ball.

At Lake Schrader, the roots of Polygonum bistorta L. ssp. plumosum (Small) Hult. [incorrectly listed as $P$. viviparum by Rausch, 1951] were stored by these voles.

Some Lake Schrader voles were trapped alive on 31 July 1951, and a colony has been maintained in the Arctic Health Research Center since that time. These animals persist in gathering all foods provided into a single "stock pile". As pointed out by Muric (1948) such activities are communal, all animals apparently taking part.

The Romanzof Mountain specimens, trapped in July and early August, were more grey in colour than is characteristic of summer specimens collected farther west. In general, specimens in winter pelage are relatively buffy in colour.

It has been possible to make limited observations on breeding and growth of the captive voles. Of the original 6 animals, all but 2 had died by 1 October 1951 , leaving a single pair. On October 15 continuous illumination was provided $(100 \mathrm{~W}$ bulb) with the hope that reproduction would be stimulated. A litter of 8 young was noticed on December 24, at which time they were estimated to be eight days old (on the basis of later observations). On December 28 , at an average weight of 7.6 grams, solid food was being consumed. On 2 January 1952 the average weight was 12.6 grams; on January 14, 17.5 grams; on January 22, 41.2 grams. First signs of sexual activity were noted on January 18. At this time the parent animals weighed 57.8 grams (female) and 46.8 grams. The original pair produced a second litter of 6 on January 3, and a third litter of 7 on January 25. The young weigh from 2 to 2.8 grams at birth, and gain an average of 2 grams per day for the first twenty days. The young are very active, and run rapidly from the nest, when disturbed, even before the eyes open.

The largest wild-trapped specimen of $M$. miurus muriei that I have collected weighed 49.8 grams, with a total length of $161 \mathrm{~mm}$. A captive male, however, attained a weight of 85.5 grams. An adult vole, laboratory-reared, is shown in Fig. 16.

\section{Relationships:}

Osgood (1901) concluded, largely on the basis of the enamel pattern of the molar teeth, that $M$. miurus is closely related to $M$. abbreviatus Miller, which occurs on Hall and St. Matthew islands. Nelson (1931) adopted this concept, and at the same time added $M$. innuitus $(=M$. oeconomus innuitus Merriam) to the abbreviatus group. Several subsequent workers have accepted this assumed relationship. 


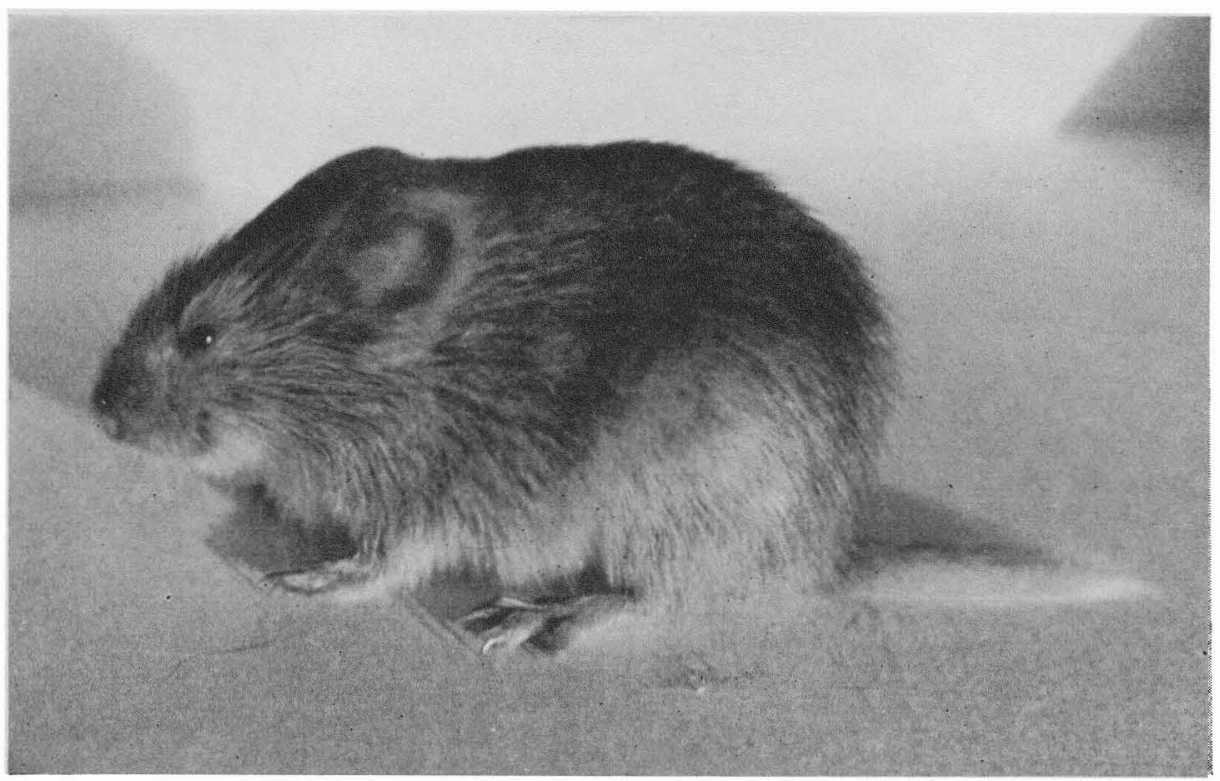

Fig. 16. Microtus miurus muriei. Subadult captive specimen. Note heavily-haired tail.

At the time he described M. abbreviatus, Miller (1899, p. 13) stated: "It is a rather large member of the typical group of the subgenus Microtus, and is more nearly related to a Siberian species which I suppose to be M. kamtschaticus (Polyakoff) than to any of the known Alaska members of the genus except M. kadiacensis." Bailey (1900) stated, in reference to M. abbreviatus, that "It belongs to the subgenus Microtus, and in general character comes nearest to the operarius group, from which it is excluded, however, by its unique molar pattern . . .". Zimmerman (1942) also compared M. abbreviatus with $M$. oeconomus; he concluded that it is closely related to $M$. oeconomus, but on the basis of molar pattern must be considered specifically distinct. Zimmerman pointed out that a grouping of $M$. abbreviatus with $M$. miurus is unnatural. The affinities of $M$. oeconomus innuitus are obvious, and I agree with Zimmerman regarding $M$. abbreviatus.

In order to determine the relationship of $M$. miurus to palearctic forms, comparisons were made with $M$. gregalis Pallas, the only Old World representative of Stenocranius. Specimens of M. g. gregalis Pallas, M. gregalis raddei Poliakov, and M. gregalis brevicauda Kastschenko have been obtained for this purpose.

It cannot be doubted that these animals are closely related. Externally, $M$. gregalis brevicauda is practically indistinguishable from $M$. miurus, even to hair texture and colour. They are likewise very similar cranially. However, there appears to be enough difference in palatal details to preclude the conclusion that they are conspecific (Fig. 17). A detailed description of M. gregalis brevicauda has been published by Dukelski (1928). Unfortunately, specimens of $M$. gregalis buturlini Ognev are not available. In view of its 

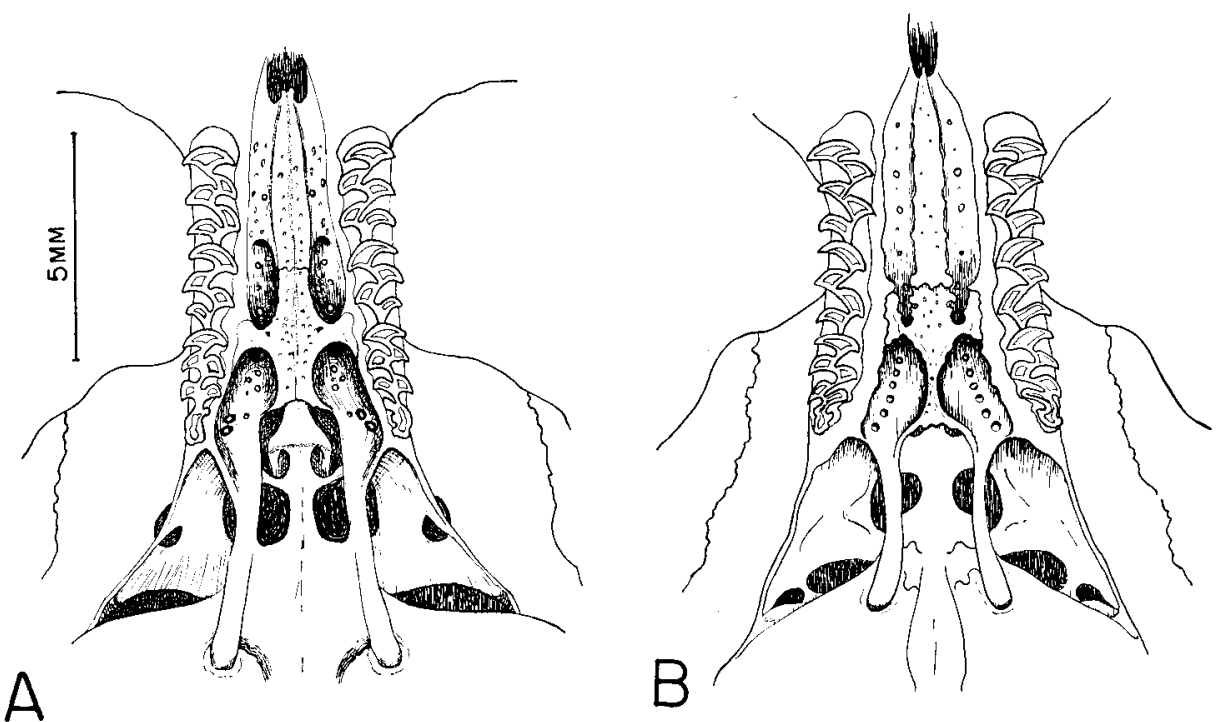

Fig. 17. Ventral portions of skulls of Microtus miurus muriei (A) and $M$. gregalis brevicauda (B), showing palatal details.

gcographic distribution (northeast Siberia) it might resemble more closely the North American form. It may be concluded that the two species have been scparated for a relatively long period of time, with the result that considerable divergence has taken place. Ognev (1950), in reference to the geographic distribution of the "gregarious field vole", stated: "The range is quite vast; from the Arkhangel'sk region to Chukotka and northern Alaska...". However, I cannot agree on the basis of material now available that they are conspecific.

The two species of Stenocranius described from northwestern Canada are M. andersoni Rand, 1945, and M. cantator Anderson, 1946. Hall and Cockrum (1952) concluded that these are also conspecific with $M$. miurus.

Castor canadensis canadensis Kuhl. Beaver.

Beaver occur in the vicinity of Arctic Village, where a few specimens were obtained. The northernmost limit of range of this species in the East Chandalar valley region has not been determined.

Two of the Nunamiut Eskimo, Kavik and Aknaniak, located a beaver dam near the head of Ikiakpuk Creek, a tributary of the John River. Although not as far north as the timbered Savioyok valley, where evidence of beaver was also observed (Rausch, 1951), this locality is neverthless well beyond the limits of taiga. This is unusual, not having been observed previously by the Eskimo nor otherwise reported insofar as I ann aware. ${ }^{1}$ Balsam poplar is common in some of the valleys on the south slope of the Brooks Range, and it would appear that this must be the only food supply of any importance.

II have been informed by letter that Pat O'Connell, white trader now living near Anaktuvuk Pass, observed an adult beaver on about 25 June 1953 at the mouth of Inukpasukruk Creek, just south of Anaktuvuk Pass. This is certainly the northernmost record for this animal in the central Brooks Range region. 
Ondatra zibethica spatulata (Osgood). Muskrat.

Muskrats are common around Arctic Village, where a small series was, collected. I have no definite information on the northern limits of their range. Porsild (1945) found muskrats very common in the Mackenzie Delta, where they occur some distance north of timber-line.

Alces alces gigas Miller. Alaskan moose.

Not more than 3 or 4 moose are killed each year in the vicinity of Arctic Village. The species occurs more abundantly a few miles to the south, however. I have no information indicating how far north this animal may range in the eastern Brooks Range.

Bobrinskiy et al. (1944) included North America in the range of Alces alces and included $A$. alces americanus Clinton and $A$. alces gigas among forms discussed. Ellerman and Morrison-Scott (1951) included "Northern North America" in the range of the species. These authors recognized only two palearctic subspecies, however, against three recognized by Bobrinskiy et al. Recently, Pcterson (1952) made a detailed study of the species; he concluded that two Old World and four North American races are valid.

Rangifer tarandus stonei Allen. Caribou.

I arge herds of caribou were observed in the Romanzof Mountains in the summer of 1951. All had gone from the region by August 1, however, leaving deeply-worn trails as evidence of their passing.

Caribou regularly occur in the vicinity of Arctic Village during the late summer, according to the inhabitants. This herd travels east and west, leaving the Chandalar River region in September, and travelling east toward Old Crow, near the head of the Porcupine River. They begin to move west in early spring (usually April) and reach the Arctic Village vicinity in late July.

As far as I have been able to determine, three distinct herds occur on the Arctic Slope within the boundaries of Alaska. Farthest to the west is the Utukok herd, which apparently winters around the headwaters of the Utukok. According to the Utukamiut, who have hunted these animals for generations, the herds migrate south usually during December, and begin a northward movement about March. Since 1933-4 caribou have become increasingly abundant along the Arctic Coast in the vicinity of Wainwright, both summer and winter. Formerly, it was necessary to travel from forty to eighty miles inland to hunt caribou. Farther east, near Barrow, they were first noticed along the coast in about 1940, and since then have continued to increase. In December 1952, travclling for seven days on the trail from Barrow to Wainwright and back, I saw numcrous caribou along the coast. No actual count was attempted, but one small group after another was observed, particularly in the region of Peard Bay. Observations made around the head of the Utukok and farther north in early October 1952, disclosed that caribou were numerous over the west end of the Arctic Slope. They appeared at this time to be travelling toward the southeast. Whether the regular occurrence of animals along the coast indicates an actual increase in the herd is difficult to say. The Eskimo are of the opinion that it does. 
The Anaktuvuk Pass serves as a main migration route for the caribou of the Central Brooks Range. Migrations here have been discussed in some detail in another paper (Rausch, 1951). There is little reason to doubt that this herd maintains its integrity over the entire year, although the animals may scatter widely in small bands. Irregularity of migration is manifested in relation to the Anaktuvuk-John River valley, but this in itself is not significant because of numerous routes within the same general region.

The herd of northeastern Alaska apparently migrates partly northwest and southeast, and partly east and west, instead of essentially north and south as do the other two herds. The animals summering in the Romanzof Mountains region probably migrate southeast into the region around the head of the Porcupine River, southwest of the Richardson Mountains. The animals occurring in the summer in the lower Chandalar River valley, in the region of Arctic Village, migrate eastward toward the head of the Porcupine.

The essentially north-south movement farther to the west is related to the distribution of the taiga zone, within which most of the caribou winter. It is known that the central herd winters in the spruce forests on the south slope of the Brooks Range. It is evident, moreover, that this herd does not go south of the mountains, since observations in this region have been made over a long enough period of time to make this certain. Many caribou passed the winter north of the mountains, on summer range, during 1952-3. The cause of this behaviour is unknown at present.

Controversial opinions are often expressed on the status of caribou on the Arctic Slope. Since decisions regarding the utilization of these animals directly affect the aboriginal population, there is a need for serious and intensive study of the problem. Tangible evidence that the arctic caribou herds are diminishing has not been produced, nor has evidence to the contrary been forthcoming. The Eskimo express the latter belief, and one cannot ignore the judgment derived from a lifetime in the Arctic and their awareness of the importance of caribou for food and clothing. It is evident that existing information is relatively worthless insofar as this problem is concerned. It is apparent that certain important factors affecting caribou have undergone significant changes in recent years:

1) Diminished importance of bunting by non-Eskimo

The white population of arctic Alaska is relatively small. The whalers, who formerly utilized great numbers of caribou for food, are gone entirely. This was discussed by Banfield (1951b). For practical purposes, it may be said that no white men winter on the Arctic Coast under conditions requiring the utilization of game for food. Farther inland, with the decline in fur values, white men do little trapping. Prospectors are few in the Brooks Range and on the Arctic Slope, for various reasons. Almost every non-Eskimo along the Arctic Coast is now employed in one capacity or another by the federal or territorial government. These people do little if any hunting. Sport hunting in this region is insignificant. 


\section{2) Decline in numbers of Eskimo}

The Eskimo are reduced in numbers, and those dependent almost entirely upon caribou exist as a pitiful few torn between their old ways and the white man's way of living. Only five settled places remain along the Arctic Coast north of Point Hope: Point Lay (50 Eskimo); Wainwright (200 Eskimo); Barrow (1,000 Eskimo) ${ }^{1}$; Barter Island (30 Eskimo); there is a single inland group in the Anaktuvuk Pass region (70 Eskimo). In addition, there is one family living at the mouth of the Colville River. The total number of Eskimo from the Brooks Range north is about 1,350 persons.

\section{3) Elimination of reindeer from the Arctic Slope}

According to information given me by people who had been actively engaged in the reindeer program at Wainwright and Barrow, there was at one time (about 1934) a total of about 22,000 reindeer in the Wainwright herd, and about 40,000 in the Barrow herd (1931). Today there is not a single reindeer remaining on the Arctic Slope except for some possibly running with the caribou. The animals were formerly scattered, in herds up to 4,000 to 6,000 , from below Wainwright to Barter Island. According to all that I can learn, overgrazing along the Arctic Coast was evident by 1916, and reindeer camps in the vicinity of Barrow were often as much as seventy miles inland (across the Meade River). It is evident that elimination of reindeer has been in some ways beneficial to the caribou. It has also resulted to some extent in increased hunting pressure.

\section{4) Changed economy of the Eskinno}

At the present time, many of the Eskimo have an income which derives directly from permanent employment. Employment on the U.S. Navy Petroleum Reserve, at Point Barrow, is especially important, and has resulted in the large and ever-growing population of Barrow Village." One now finds there people from villages as far away as Nome and Noatak, although the majority consists of people from the Barrow region, Wainwright, and Point Lay. Concentration in few villages and cash income affect caribou in two ways: 1) hunting is lessened in amount, since men with full-time employment have no time for it, and no need for doing so; 2) hunting pressure is local; the Barrow and Wainwright people both depend largely on the animals which come near the coast. Some Wainwright people travel up the Kuk to kill caribou, and the Point Lay people also hunt inland to a considerable extent. There is not, however, the generalized hunting pressure of former years. The inland people depend upon the caribou migrating through the Anaktuvuk-

${ }^{1}$ At the present time, as the result of the termination of oil exploration activities on the Arctic Coast by the U.S. Navy, there is no longer opportunity for employment of the coastal Eskimo, Consequently, all of these figures are subject to change.

2The population of Barrow Village is now decreasing since there is no longer opportunity for employment on the U.S. Navy Petroleum Reserve. Many of these people will return to the villages of their origin; others are going to Fairbanks and Anchorage to obtain work for which they have been trained. This situation may result in a greater dependency upon hunting, if other developmental activities do not provide opportunities for employment along the Arctic Coast. 
John River valleys for their supply of meat and hides. The migration pattern during both 1951 and 1952 was such that few animals were available, with the result that for most of these years the people had to live on substitute food, mostly purchased from the white man.

Other controversial points have been discussed regarding the Eskimocaribou relationships. It has been stated that the Fskimo of pre-firearm days were unable to kill many caribou. This view is not altogether tenable, for two reasons: 1) a great many more people lived inland and caribou were hunted much more both by them and by the coast people, since there were few substitute foods inland and nothing else suitable for clothing. 2) The Eskimo had developed some very effective means by which caribou were taken; two of these, the kangigak (corral) with snares, and the method of driving into a lake for spearing from kayaks were especially effective. The entire group took part in these activities. I have seen the latter method in use, and know that it is very effective.

The twelve families comprising the total Nunamiut (Inland) population still living in the old way maintain large dog teams. These are considered necessary; all are kept carefully tethered and all are used. Criticism of this practice can hardly be justified without providing an alternative way of life.

My experience in the region below the west end of the Brooks Range has been limited, so that detailed observations have not been made. The people of Noatak, Noorvik, Selawik, Shungnak, etc., occasionally have opportunity to kill caribou when there are irregular migrations, and this must be considered in evaluating hunting pressure on the Utukok herd, which presumably at times migrates well into the Noatak country. As far as I have been able to determine, however, caribou rarely come so far to the south. Some of the people travel inland to hunt. The kill by the Barter Island people and the Indians of Arctic Village, at the east end of the Brooks Range, is small. If the eastern herd is separate, as appears to be the case, this hunting has no effect of any importance.

Regardless of the factors discussed above, it must be recognized that for adequate clothing Eskimo must have caribou hides. It is well known that the hides of calves and cows, killed during the warm months, are most suitable. Winter boots of caribou legs are the only complctely adequate type of footwear available, to Eskimo and white man alike, and the legs of 2 caribou are required to make one pair of boots. The skins of 2 cow caribou, or 3 calves, are required for a man's parka. For winter use, a double parka is needed, requiring from 4 to 6 animals. For a woman's parka, 2 large cow hides or 3 small ones are required, and for children a single skin is sufficient. Mittens and boot soles are made of hides of different types (winter skins for the former; thick hide of old bulls killed in the fall for the latter). There are other uses for caribou hides which are equally important, reported earlier (Rausch, 1951). Banfield (1951b) stated that 25 caribou hides are required annually by Canadian Eskimo to clothe a family of four.

Caribou may now be killed legally north of the Arctic Circle from August 20 to February 28 . Calves are entirely excepted, and the legal kill 
per hunter is 3 animals a year. It is obvious that it is impossible to obtain legally enough hides for clothing needs.

The attitude in Canada toward utilization of wildlife resources by the Eskimo is in contrast with that obtaining in Alaska. At the recent Conference on Eskimo Affairs": "It was agreed that Eskimo should be encouraged and helped to live off the land and to follow their traditional way of life". These opposing views deserve careful analysis with respect to the eventual effect on both wildlife and aboriginal populations.

Caribou management cannot be discussed without some mention of wolf control, since in Alaska the one is the justification of the other. Indiscriminate destruction of carnivores has long been considered biologically unsound by leading ecologists, but the practice persists. Without discussing the place of the wolf as such in the biotic community, this opportunity is taken to point out the possibility that wolf control in Alaska may be contrary to the purposes of its advocates.

Palmer in 1926 pointed out that reindeer range, once depleted, may require as long as twenty to thirty years to recover. As a result of reindeer herding, there has already been some depletion of the range along the Arctic Coast. In the absence of an accurate census of the arctic caribou herds, and a lack of appropriate ecological studies to determinc carrying capacity, range utilization, and migration patterns, it is not possible now to know whether an increase in the arctic herds would be desirable. Leopold and Darling (1952) have discussed the problem in detail. Wolf control without scientific basis is unwise at best, and may be detrimental.

The relationship of wolves and diseased caribou appears more important, and is tangible. In the northern countries where reindeer husbandry has been carried on for many years, hoof-rot has been an important disease. This disorder, occurring only in the summer, has many local names, and Actinomyces necrophorus Lehmann and Neumann (=Spherophorus necrophorus (Flügge)) is regarded as the causative agent. Hadwen and Palmer (1922) in regard to this disease in reindeer stated: "All foot troubles are serious when they occur in grazing animals; for as soon as the animal has difficulty in walking it can not feed properly and soon becomes thin and worthless. If the lameness is severe and likely to becone worse it is the best policy to destroy the animal ... the risk of passing on the disease is eliminated."

The causative organism, isolated from typical foot lesions in reindeer from a herd near Noatak, has been identified at the Arctic Health Research Center. It has not so far been isolated from caribou, but there is considerable evidence that it occurs in this animal also. Arthur H. Lachenbruch, U.S. Geological Survey, has kept accurate records during five summers of field work (1946-50) in the Brooks Range and on the Arctic Slope. During the last three weeks of August 1946 he observed a high prevalence of foot disorder in a caribou herd distributed along the lower Kurupa River and several miles down the Colville. He estimated the herd to number 20,000 animals, and concluded that at least 1 per cent of the animals was crippled. Dead animals were numerous, and

\footnotetext{
"Conference on Eskimo Affairs." Arctic, Vol. 5 (1952) pp, 193-5.
} 
still-living caribou could be run down on foot. The lesions he described to me were characteristic of necrophorus infection. Individuals in a herd observed in the late summer of 1947 on the Canning River showed apparently the same condition, as did animals observed near Lake Schrader in 1948. In the fall of 1952 there was a report of many crippled caribou having been seen by Navy personnel near the head of the Utukok River. Robert F. Scott, Biologist, U.S. Fish and Wildlife Service, and I attempted to locate these animals from the air, but were unsuccessful. In view of the vast country involved, and the number of caribou present, our failure to find the affected herd does not imply that the report was false.

On the basis of the above-mentioned records, it may be assumed that caribou are subject to a crippling hoof disease. Whether this is necrophorus infection is relatively unimportant. It is obvious, however, that rapid elimination of the diseased animals would be desirable to minimize infection. The Lapps and others have followed the practice of moving their herds to new, uncontaminated grounds following the outbreak of hoof disease. Wolves readily capture such afflicted animals. Moreover, wolf activities would probably result in continual movement of the normal animals, and the opportunities for infection would be minimized.

It is believed that the elimination of inferior animals from the caribou herds is an important function of wolves. Such factors should be taken into consideration when it is suggested that large-scale wolf destruction be practiced as a means to increase the numbers of caribou. It is significant that there is no indescriminate wolf control practiced in arctic Canada (A. W. F. Banfield, personal communication), where the knowledge of caribou ecology is far advanced over that in Alaska. The wolf is a part of the boreal fauna, and it has its place.

According to Bobrinskiy et al. (1944), the range of Rangifer tarandus comprises: "Zone of tundra and taiga of Europe and North America, islands of the Polar Sea." Ellerman and Morrison-Scott (1951) also recognized but a single holarctic species. There appears to be no justification for the use of the name Rangifer arcticus (Richardson) for the North American barrenground caribou.

Ovis canadensis dalli Nelson. Mountain sheep.

Mountain sheep were numerous in northeastern Alaska during the summer of 1951. A few old skulls were found near Lake Schrader, but no specimens were collected. Sheep occur within twenty miles of Arctic Village. The animals of the eastern Brooks Range region are subjected to little hunting pressure.

Sushkin (1925) in a review of a paper by Nasonov, stated that Ovis dalli is conspecific with the palearctic O. nivicola Eschscholtz. Bobrinskiy et al. (1944) included North America in the range of O. nivicola. They recognized four palearctic subspecies, but did not discuss the North American forms. More recently, Ellerman and Morrison-Scott (1951) have concluded that both $O$. nivicola and $O$. dalli are conspecific with the North American O. canadensis 
Shaw. Regarding this, they stated: "We also refer nivicola as a race to canadensis, though this is a purely nomenclatural difference; it is not clear why the Russians do not do likewise since they agree that the bighorn of NorthEastern Siberia and North-Western America are conspecific, and canadensis is the prior name."

The author is indebted to many for generous aid given in connection with this study, and wishes to thank all who have contributed. This opportunity is taken to express appreciation to:

Dr. David H. Johnson, Associate Curator, Division of Mammals, U.S. National Museum, for the loan of numerous specimens and extended use of Museum facilities in 1949 and 1950; Colin Campbell Sanborn, Curator of Mammals, Chicago Natural History Museum, for the loan of specimens and other assistance; Dr. Charles P. Lyman, Associate Curator of Mammals, Museum of Comparative Zoology, Harvard College, for making available important palearctic material; Dr. Murray L. Johnson, Puget Sound Museum, College of Puget Sound, Tacoma, Washington, for the loan of marmot material; Dr. R. M. Anderson, Hon. Curator of Mammals, National Museum of Canada, Ottawa, for important suggestions; Dr. A. W. F. Banfield, Chief Mammalogist, Canadian Wildlife Service, for the loan of specimens from northwestern Canada.

U.S. Fish and Wildlife Service biologists have assisted in various ways. Thanks are expressed particularly to: Russell R. Hoffman, Refuge Manager, Kodiak; W. K. Clark, also of Kodiak; Robert F. Scott, Fairbanks; David Spencer, Refuge Supervisor, Kenai; Robert D. Jones, Refuge Manager, Cold Bay; and Dr. John L. Buckley, Cooperative Wildlife Research Unit, University of Alaska.

Dr. Ira L. Wiggins, Scientific Director, Arctic Research Laboratory, Office of Naval Research, Point Barrow, extended the use of laboratory facilities and provided logistic support on numerous occasions.

I want to thank especially E. L. Schiller and B. B. Babero, of the Arctic Health Research Center, for important aid in the field work, and Miss R. V. Sacressen, also of this Center, for field and technical assistance.

\section{References}

Allen, G. M. 1914. "Mammals" in "Notes on the birds and mammals of the arctic coast of east Siberia." Proc. New Eng. Zool. Club, Vol. 5, pp. 49-66.

1919. "The American collared lemmings (Dicrostonyx)." Bull. Mus. Comp. Zool. Vol. 62, pp. 509-42.

Allen, J. A. 1902. "List of mammals collected in Alaska by the Andrew J. Stonc Expedition of 1901." Amer. Mus. Nat. Hist. Bull. Vol. 16, pp. 215-30.

1903a. "Report on the mammals collected in northeastern Siberia by the Jesup North Pacific Expedition, with itincrary and field notes, by N. G. Buxton.' Bull. Amer. Mus. Nat. Hist. Vol. 19, pp. 101-84. 1903b. "Mammals collected in Alaska and northern British Columbia by the Andrew J. Stone Fxpedition of 1902." Bull. Amer. Mus. Nat. His. Vol. 19, pp. $521-67$.

Anderson, R. M. 1934. "Notes on the distribution of the hoary marmots." Can. FieldNat. Vol. 48, pp. 61-3.

1937. "Birds and mammals" in 'Canada's western northland.' Ottawa: Dept. of Mines and Res. pp. 97-129.

1943. "Summary of the large wolves of Canada, with description of three new arctic races." J.Mammal. Vol. 24, pp. 386-93.

1946. 'Catalogue of Canadian recent mammals.' Bull. Nat. Mus. Can.

No, 102, $238 \mathrm{pp}$. 
Anderson, R. M. and A. L. Rand. 1945a. "A new shrew from arctic North America." Can. Field-Nat. Vol. 59, pp. 62-4.

1945b. "The varying lemming (genus Dicrostonyx) in Canada." I. Mammal. Vol. 26, pp. 301-6.

Bailey, A. M. and R. W. Hendee. 1926. "Notes on the mammals of northwestern Alaska." J. Mammal. Vol. 7, pp. 9-28.

Bailey, V. 1900. 'Revision of American voles of the genus Microtus.' North Amer. Fauna, No. 17, U.S. Dept. Agri. 88 pp.

Baker, R. H. 1951. "Mammals taken along the Alaska Highway." Mus. Nat. Hist. U. Kans. Publ. Vol. 5, pp. 87-117.

Banfield, A. W. F. 1951 a. "Notes on the mammals of the Mackenzie District, Northwest Territories." Arctic, Vol. 4, pp. 113-21. mimeo. $52 \mathrm{pp}$

1951b. "The barren-ground caribou." Canada, Dept. Res. and Dev.

Bobrinskiy, N. A., B. A. Kuznetsov, and A. P. Kuzyakin. 1944. 'Opredelitel' mlekopitayushchikh S.S.S.R.' Moscow: 440 pp.

Coues, E. 1877. 'Fur-bearing animals: a monograph of North American Mustelidx.' Dept. of the Interior, Misc. Publ. No. 8, 348 pp.

Davis, W. B. 1944. "Geographic variation in brown lemmings (genus Lemmus)." Murrelet, Vol. 25, pp. 19-25.

Degerbol, M. and P. Freuchen. 1935. 'Report of the mammals collected by the Fifth Thule Expedition to arctic North America: Zoology, I. Mammals.' Vol. 2, No. 4-5. Copenhagen: $278 \mathrm{pp}$.

Dukelski, N. M. 1928. "Materialen über die Säugetier-Fauna des Jakutien-Gebietes (Nordost-Sibirien)." Zool. Anz. Vol. 78, pp. 102-7.

Ellerman, J. R. 1949. "On the prior name for the Siberian lemming and the genotype of Gilis Lirxleben." Ann and Mag. Nat. Hist. 12th Ser. Vol. 2, pp. 893-4.

Elleman, J. R. and T. C. S. Morrison-Scott. 1951. 'Checklist of palaearetic and Indian mammals: 1758 to 1946.' London: British Museum (Natural History), 810 pp.

Elliott, D. G. 1905. "Descriptions of apparently new mammals of the genera Ovibos, Cynomys, and Mustela." Proc. Biol. Soc. Wash. Vol. 18, pp. 135-40.

Gilmore, R. M. 1933. "Notes on the Unalaska collared lemming (Dicrostonyx unalascensis analascensis Merriam)." J. Mammal. Vol. 14, pp. 257-8.

1946. "Arctic mammalogy" in "A program of desirable scientific investigations in arctic North America.' Bull. No. 1, Arctic Inst. North Amer. pp. 35-43.

Goldman, E. A. 1941. "Three new wolves from North America." Proc. Biol. Soc. Wash. Vol. 54, pp. 109-13.

Hadwen, S. and L. J. Palmer. 1922. 'Reindeer in Alaska.' U.S. Dept. Agri. Bull. No. 1089, $74 \mathrm{pp}$.

Hall, E. R. 1929. "Mammals collected by Charles D. Brower at Point Barrow, Alaska." U. Cal. Publ. Zool. Vol. 30, Pp. 419-25.

1944. "Classification of the ermines of eastern Siberia." Proc. Cal. Acad. Sci. Vol. 23, pp. 555-60.

1951a. "A synopsis of the North American Lagamorpha." Mus. Nat. Hist. U. Kans. Publ. Vol. 5, pp. 119-202.

1951b. "American weasels." Mus. Nat. Hist. U. Kans. Publ. Vol. 4, pp. 1-466.

Hall, E. R. and E. L. Cockrum. 1952. "Comments on the taxonomy and geographic distribution of North American nicrotines." Mus. Nat. Hist. U. Kans. Pabl. Vol. 5, pp. 293-312.

Hall, E. R. and R. M. Gilmore. 1932. "New mammals from St. Lawrence Island, Bering Sea, Alaska." U. Cal. Publ. Zool. Vol. 38, pp. 391-404.

1934. "Marmota caligata broweri, a new marmot from northern Alaska." Can. Field-Nat. Vol. 48, pp. 57-9.

Hanson, H. C. 1952. "A new race of red-backed vole (Cletbrionomys) from the Barren Grounds of Canada." J. Mammal. Vol. 33, pp. 500-2.

Hinton, M. A. C. 1926. 'Monograph of the voles and lemmings (Microtinæ).' London: British Museum, $488 \mathrm{pp}$.

Howell, A. H. 1915. 'Revision of the American marmots.' Nortb Amer. Fauna, No. 37. U.S. Dept. Agri. $80 \mathrm{pp}$.

1936. "Descriptions of three new red squirrels (Tamiasciurus) from North America," Proc. Biol. Soc. Wasb. Vol. 49, pp. 133-6. 
1938. 'Revision of the North American ground squirrels.' North Amer. Fauna, No. 56, U.S. Dept. Agri. 256 pp.

Hrdlicka, A. 1944. "The anthropology of Kodiak Island. Appendix B. Animal and plant life." Publ. Wistar Inst. Anat. and Biol. pp. 475-80.

Jackson, H. H. T. 1928. 'A taxonomic review of the American long-tailed shrews.' North Amer. Fauna, No. 51, U.S. Dept. Agri. 238 pp.

Johnson, S. 1947. "Rovdyra" in 'Norges Dyreliv.' Vol. I, Pattedyr. Oslo: 506 pp.

Lampio, T. 1951. 'On the sex ratio, sex differentiation, and regional variation in the marten in Finland.' Papers on Game Res. (Helsinki) Vol. 7, 20 pp.

Leffingwell, E. de K. 1919. 'The Canning River region, northern Alaska.' U.S. Geol. Surv. Prof. Paper, No. 109, 251 pp.

Leopold, A. S. and F. F. Darling. 1952. "Effects of land use on ranges and populations of moose and caribou in Alaska." Paper presented at Third Alaskan Sci. Conf., 22-7 Sept. 1952.

Merriam, C. H. 1900. "Papers from the Harriman Alaska lixpedition. I. Description of twenty-six new mammals from Alaska and British Columbia." Proc. Wash. Acad. Sci. Vol. 2, pp. 13-30.

1918. 'Review of the grizzly and big brown bears of North America.' Nortb Amer. Fauna, No. 41, U.S. Dept. Agri. 136 pp.

Miller, G. S. 1899. "A new vole from Hall Island, Bering Sea." Proc. Biol. Soc. Wash.

Vol. 13, pp. 13-4.

1912. "The names of the large wolves of northern and western North America." Smithsonian Misc. Coll. Vol. 59 (1913) pp. 1-5.

Murie, A. 1944. 'The wolves of Mt. McKinlcy.' U.S. Park Serv. Fauna Ser. No. 5, $238 \mathrm{pp}$.

1948. "The mysterious mouse." Audubon Mag. Vol. 50, pp. 202-10.

Nelson, F. W. 1929. "Description of a new lemming from Alaska." Proc. Biol. Soc. Wash. Vol. 42, pp. 143-6.

1931. "A new vole of the subgenus Stenocranizes from Alaska." J. Manmal. Vol. 12, pp. 310-2.

Ognev, S. 1. 1935. 'Zveri S.S.S.R. i prilezhashchikh stran.' Moscow: Vol. 3, 752 pp.

$812 \mathrm{pp}$.

1947. 'Zveri S.S.S.R. i prilezhashchikh stran.' Moscow-Leningrad: Vol. 5,

$736 \mathrm{pp}$.

1950. 'Zveri S.S.S.R. i prilezhashchikh stran.' Moscow-Leningrad: Vol. 7,

Osgood, W. H. 1900. 'Results of a biological reconnaissance of the Yukon River region.'

Nortb Amer. Fanna, No. 19, U.S. Dept. Agri. pp. 7-45.

1901. 'Natural history of the Cook Inlet region, Alaska.' North Amer.

Fauna, No. 21, U.S. Dept. Agri. pp. 51-87.

Vol. 16, pp. $25-7$.

1903. "Two new spermophiles from Alaska." Proc. Biol. Soc. Wash.

1904. 'A biological recomnaissance of the base of the Alaska Peninsula.'

Nortb Amer. Fauna, No. 24, U.S. Dept. Agri. 86 pp.

1907. "A collection of mammals from the region of Mount McKinley,

Alaska." Proc. Biol. Soc. Wash. Vol. 20, pp. 59-63.

1909. 'Biological investigations in Alaska and Yukon Territory.' North. Amer. Fanna, No. 30, U.S. Dept. Agri. 95 pp.

Palmer, L. 1926. 'Progress of reindeer grazing investigations in Alaska.' U.S. Dept. Agri. Bull. No. 1423,35 pp.

Peterson, R. L. 1952. "A review of the living representatives of the genus Alces." Cont. Roy. Ont. Mus. Zool. Palaeont. Vol. 34, pp. 1-30.

Porsild, A. E. 1945. "Mammals of the Mackenzie Delta." Can. Field-Nat. Vol. 59, pp. 4-22.

Preble, E. A. 1908. 'A biological investigation of the Athabaska-Mackenzie region.' Nortb Amer. Fanna, No. 27, U.S. Dept. Agri. 574 pp.

Quay, W. B. 1951. "Observations on mammals of the Seward Peninsula, Alaska." J Mantmal. Vol. 32, pp. 88-99.

Rand, A. I. 1945. 'Manmal investigations on the Canol Road, Yukon and Northwest Territories, 1944.' Bull. Nat. Mus. Can. No. 99, Biol. Ser. No. 28, 52 pp.

Rausch, R. 1950a. "Observations on a cyclic decline of lemmings (Lemmus) on the Arctic Coast of Alaska during the spring of 1949." Arctic, Vol. 3, pp. 166-77. 
1950b. "Notes on microtine rodents from the Brooks Range, arctic Alaska." J. Wash. Acad. Sci. Vol. 40, pp. 133-6.

1951. "Notes on the Nunamiut Eskimo and mammals of the Anaktuvuk Pass region, Brooks Range, Alaska." Arctic, Vol. 4, pp. 147-95.

1952. "Studies on the helminth fauna of Alaska. XI. Helminth parasites of microtine rodents - taxonomic considerations." J. Parasit. Vol. 38, pp. 415-44.

1953. "On the land mammals of St. Lawrence Island." Murrelet (in press).

Richardson, J. R. 1829. 'Fauna Boreali-Americana. Part I: The Quadrupeds.' London: John Murray, $300 \mathrm{pp}$.

Setzer, H. W. 1952. "A new subspecies of Microtus oeconomus from Alaska." Proc. Biol. Soc. Wash. Vol. 65, pp. 75-6.

Simpson, G. G. 1945. "The principles of classification and a classification of mammals." Bull. Amer. Mus. Nat. Hist. Vol. 85, pp. 1-350.

Stone, W. 1900. "Report on the birds and nammals collected by the Mcllhenny Expedition to Pt. Barrow, Alaska." Proc. Philadelph. Acad. Sci. Pt. 1, pp. 4-49.

Strecker, R. L., F. A. Ryser, W. J. Teitz, and P. R. Morrison. 1952." "Notes on mammals from Alaska." J. Mammal. Vol. 33, pp. 476-80.

Sushkin, P. P. 1925. "The wild sheep of the Old World and their distribution." $J$. Mammal. Vol. 6, pp. 145-57.

Swarth, H. S. 1931. "The lemming of Nunivak Island, Alaska." Proc. Biol. Soc. Wash. Vol. 44, pp. 101-4.

True, F. W. 1885. "A provisional list of the mammals of North and Central America, and the West Indian Islands." U.S. Nat. Mus. Proc. Vol. 7 (1884) pp. 587-611.

Wehrli, H. 1935. "Zur Osteologie der Gattung Marmota Blumenb. (Arctomys Schreb.)." Ztscbr. Säugetierk. Vol. 10, pp. 1-32.

Wright, P. L. and R. Rausch. 1953. "An analysis of some wolverine reproductive tracts with comments on cranial characters." Manuscript.

Young, S. P. and E. A. Goldman. 1944. 'The wolves of North America.' Washington: American Wildlife Institute, $636 \mathrm{pp}$.

Zimmerman, K. 1942. "Zur Kenntnis von Microtus oeconomis (Pallas)." Archiz. Naturgeschichte, N.F. Vol. 11, pp. 174-97. 